\title{
Founding-Era Socialism: The Original Meaning of the Constitution's Postal Clause
}

\author{
Robert G. Natelson*
}

\begin{abstract}
The Constitution's Postal Clause granted Congress power to "establish Post Offices and post Roads." This Article examines founding-era legal and historical materials to determine the original meaning and scope of the Postal Clause. It concludes that the Clause authorized Congress to pass all legislation necessary to create, operate, and regulate a unified transportation, freight, and courier system, although it also limited congressional authority in some respects. The founding-era reasons for the postal system were revenue, promotion of commerce, and political control. The Article also corrects some inaccurate claims about the Clause previously advanced by commentators.
\end{abstract}

\section{KEYWORDS}

Postal Clause; Post Roads; Original Meaning U.S. Constitution; Benjamin Franklin; British Royal Post Office.

\section{CONTENTS}

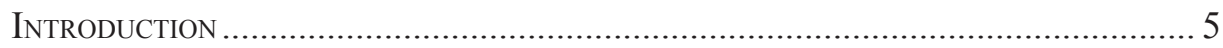

A. The Anomalous Character of the Postal Clause................................... 5

B. This Article's Structure and Method ................................................. 6

I. Background History: The British Imperial Postage System....................... 7

A. Why British Practice is Relevant ......................................................... 7

B. The English Beginnings ........................................................... 8

C. Vocabulary and Operations of the British Postal System.......................9

* Professor of Law (ret.), The University of Montana; Senior Fellow in Constitutional Jurisprudence, the Independence Institute, Denver, Colorado; Senior Fellow in Constitutional Jurisprudence, Montana Policy Institute, Bozeman, Montana. Some of the author's observations about business practices derive from his private sector experience.

The author acknowledges these individuals who helped make this article possible: Jonathan Miceli, Sturm College of Law, University of Denver (J.D. 2018), for research assistance; Virginia Dunn, Archives and Library Reference Service Manager, and Cassandra Farrell, Senior Map Archivist, both at the Library of Virginia; Professor David Kopel, Sturm College of Law, the University of Denver and Research Director of the Independence Institute, for his continued support; Dr. Anne Richardson Oakes for helpful editing and support; and Elizabeth J. Natelson, for her careful editing. 
D. Purposes of the British Postal System 14

E. The British Post Office Becomes Imperial: The Statute of 1711 ... 18

F. Motifs in the Development of the Imperial Postal System 20

II. Background History: The Colonial American Postal System. 24

A. The American Post Office as the Successor to the British Imperial Post Office .24

B. American Colonial Operations and Ben Franklin . .26

C. The American Postal System in the Sunset of British Rule 27

III. The Continental Post Office in the Sunrise of Independence ......... 31

A. The Vocabulary of the Continental Post Office .............................. 31

B. The Purposes of the Continental Post Office …………………….... 33

C. Congress Decides to Emulate the British.......................................... 35

D. Regularizing Postal Law Under the Articles of Confederation ..... 36

E. The Woes of a State-Owned Enterprise............................................ 38

1. Problems Inherited from the British Model................................. 38

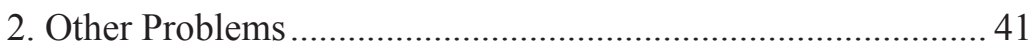

IV. The Drafting of the Postal Clause ..................................................... 43

A. Why Adopt a Postal Clause?......................................................... 43

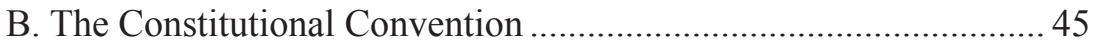

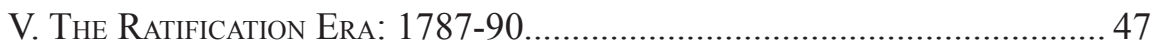

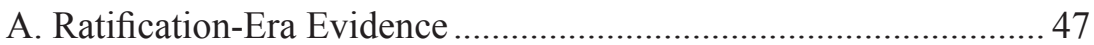

B. The Ratification Debates in State Conventions and in Public........ 47

C. Ratification-Era Proceedings in the Confederation Congress........ 52

D. Ratification Era Proceedings in the First Federal Congress .......... 53

VI. The Original Meaning of the Postal Clause...................................... 55

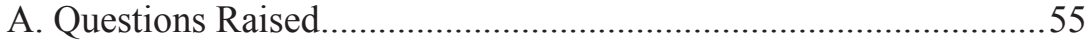

B. What Was A "Post Road?" .............................................................56

C. What Did "Establish" Mean, and Did the Power to "Establish" a Postal System Include Defining and Punishing Postal Crimes? 56 
D. Did the Postal Clause Permit the Post Office to Pursue Entrepreneurial Opportunities? If So, Which Ones?.

E. Did the Clause Authorize Constructing New Roads and Facilities or Merely Designating Existing Ones?....................................58

F. Did the Grant of Power to Establish Post Roads Include an Incidental Grant of Eminent Domain Authority? .......................59

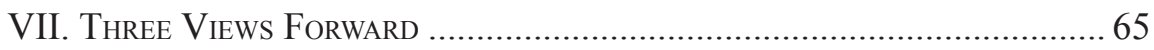

A. Limitations Imposed by the Bill of Rights. 65

B. The Federal Congress's Postal Act of 1792 — and Implications for the Nondelegation Principle 66

C. The Commendable Future of Ebenezer Hazard ${ }^{1}$ 70

Bibliographical Footnote. Following are the sources referred to in this article more than once:

\section{Statutory Material and Primary Sources}

1 Annals of Cong. (1789) (Joseph Gales ed., 1834) [hereinafter Annals of Cong.]

Documentary History of the First Federal Congress of the United States of America, March 4, 1789-March 3, 1791 (Charlene Bangs Bickford, Kenneth R. Bowling, William Charles diGiacomantonio, and Helen E. Veit eds. 1972-2012) [hereinafter FIRST CONGRESS]

The Documentary History of the Ratification of the Constitution (Merrill Jensen, John P. Kaminski \& Gaspare J. Saladino eds., 1976-2013) [hereinafter DocumENTARY HISTORY]

9 Encyclopaedia Britannica (J. Balbour \& Co., 2d ed. 1778) [hereinafter Encyclopaedia BRITANNICA]

9 English Historical Documents: American Colonial Documents to 1776 (Merrill Jensen ed. 1955) [hereinafter EHD]

Journals of the Continental Congress 1774-1789 (Government Printing Office 190437) [hereinafter J. Cont. Cong.]

Letters of Delegates to Congress, 1774-1789 (Library of Congress, 1976-2000), https://memory.loc.gov/ammem/amlaw/lwdglink.html [hereinafter DeLEGATE LetTERs]

ReCords of the Federal Convention of 1787 (Max Farrand ed., 2d ed. 1937) [hereinafter FARRAND]

Adam Smith, An Inquiry Into the Nature and Causes of the Wealth of Nations (C.J. Bullock ed., F.P. Collier 1909) (1776) [hereinafter Sмітн, WеALth]

\section{History, Commentary and Poetry}

Joseph M. Adelman, "A Constitutional Conveyance of Intelligence. Public and Private": The Post Office, the Business of Printing, and the American Revolution., 11 ENTERPRISE \& Soc'y 711 (2010) [hereinafter Adelman]

William Baude, Re-thinking the Federal Eminent Domain Power, 122 Yale L.J. 1738 (2013) [hereinafter Baude]

William Blackstone, Commentaries (1765)

Colonial and State Records of North Carolina (1895) (multiple volumes) [hereinafter N.C. RECORDS] 
6 The Life and Works of William Cowper (Robert Southey ed., Henry G. Bohn 1854) [hereinafter Cowper]

David P. Currie, The Constitution in Congress: The Second Congress, 1791-1793, 90 Nw. U. L. Rev. 606 (1996) [hereinafter Currie]

Anuj C. Desai, The Transformation of Statutes into Constitutional Law: How Early Post Office Policy Shaped Modern First Amendment Doctrine, 58 Hastings L.J. 671 (2007) [hereinafter Desai]

Kenneth Ellis, The Post Office in the Eighteenth Century: A Study in Administrative History (1958) [hereinafter ELLIS]

Hugh Finlay, Journal Kept by Hugh Finlay (Frank H. Norton ed. 1867) (1774) [hereinafter FINLAY]

J. C. Hemmeon, The History of the British Post Office (1912) [hereinafter Hemmeon] Alexander Hamilton, James Madison \& John Jay, The Federalist (George W. Carey \& James McClellan eds. 2001) [hereinafter The Federalist]

Stewart H. Holbrook, The Old Post Road (1962) [hereinafter Holbrook]

Giles Jacob, Lex Constitutionis: or the Gentleman's Law (Eliz. Nutt \& R. Gosling 1719) [hereinafter $\mathrm{J}_{\mathrm{ACOB}}$ ]

Eric Jaffe, The King's Best Highway: The Lost History of the Boston Post Road, the Route That Made America (2010) [hereinafter JafFe]

Richard R. John, Spreading the News: The Ameican Postal System from Franklin to Morse (1995) [hereinafter JoHn, SPREAdING]

Herbert A. Johnson, Imported Eighteenth-Century Law Treatises in American LibraRies 1700-1799 (1978) [Johnson, Imported TREatises]

Herbert Joyce, The History of the Post Office from Its Establishment Down to 1836 (1893) [hereinafter JOYCE ${ }^{]}$

Gary Lawson, Geoffrey P. Miller, Robert G. Natelson \& Guy I. Seidman, The Origins of the Necessary and Proper Clause (2010) [hereinafter Lawson, et al.]

D. D. T. Leech, History of the Post Office Department. 1789-1879 (1879) [hereinafter LEECH]

William Lewins, Her Majesty's Mails: A History of the Post-Office, and an Industrial Account of its Present Condition (2d ed. 1865) [hereinafter Lewins]

Jerry L. Mashaw, Recovering Administrative Law: Federalist Foundations, 1787-1801, 15 YALE L.J. 1256 (2006) [hereinafter Mashaw]

Robert G. Natelson, Founding-Era Conventions and the Meaning of the Constitution's "Convention for Proposing Amendments," 65 Fla. L. REv. 615 (2013) [hereinafter Natelson, Conventions]

Robert G. Natelson, The Enumerated Powers of States, 3 Nev. L.J. 469 (2003) [hereinafter Natelson, Enumerated]

A.M. Ogilvie, The Rise of the English Post Office, 3 THE Econ. J. 443 (1893) [hereinafter Ogilvie]

George Pilcher, Ebenezer Hazard and the Promotion of Historical Scholarship in the Early Republic, 56 Penn. History 3 (1989) [hereinafter Pilcher]

Wesley Everett Rich, The History of the United States Post Office to the Year 1829 (1924) [hereinafter Rich]

Lindsay Rogers, The Postal Power of Congress: A Study in Constitutional Expansion (1915) [hereinafter ROGERS]

Daniel P. Roper, The United States Post Office (1917) [hereinafter Roper]

Robert J. Shapiro, The Basis and Extent of the Monopoly Rights and Subsidies Claimed by the United States Postal Service (2015) [hereinafter Shapiro]

Howard Robinson, The British Post Office: A History (Princeton Univ. Press 1948) [hereinafter RoBINSON]

Robert J. Shapiro, The Basis and Extent of the Monopoly Rights and Subsidies Claimed by the United States Postal Service (2015), http://www.sonecon.com/docs/ 
The Congress shall have Power ... To establish Post Offices and post Roads.

socialism, n. . 2. . A theory or system of social organization based on state or collective ownership and regulation of the means of production, distribution, and exchange for the common benefit of all members of society ...

OXford English Dictionary (2016)

The post office is ... perhaps the only mercantile project which has been successfully managed by, I believe, every sort of government.

Adam Smith, The Wealth of Nations $(1776)^{2}$

\section{INTRODUCTION}

\section{A. The Anomalous Character of the Postal Clause}

In December, 1772 the British government designated Hugh Finlay, as "Surveyor [inspector] of the Post roads in the Continent of North America." ${ }^{3}$ He was ordered to evaluate the postal system in the thirteen North American colonies south of Canada. ${ }^{4}$

Finlay was a diligent officer. ${ }^{5}$ Beginning in September, 1773, he made his way from Quebec City to Falmouth, Massachusetts (now Portland, Maine), led by Indian guides, traveling through the wilderness by foot and canoe.

Falmouth was the northern terminus of the 13-colony post road. From there Finlay followed the road though Boston, Providence, New Haven and New York, and then sailed to Philadelphia, Pennsylvania and to Charles Town, South Carolina. From Charles Town he proceeded overland to the southern post road terminus at Savannah, Georgia, and thence north to Virginia.

studies/Study_of_USPS_Subsidies-Shapiro-Sonecon-March_25_2015.pdf [hereinafter SHAPIRO]

Fred Shelley, Ebenezer Hazard: America's First Historical Editor, 12 WM. \& MARY Q. 44 (1955) [hereinafter Shelley]

William Smith, The Colonial Post-Office, 21 Am. Hist. Rev. 258 (1916) [hereinafter Smith]

I.K. Steele, Finlay, Hugh, 5 Dictionary of Canadian Biography (1983), available at http://www.biographi.ca/en/bio/finlay_hugh_5E.html (last visited Feb. 28, 2018) [hereinafter Steele, Finlay]

William B. Stoebuck, A General Theory of Eminent Domain, 47 WASH. L. REv. 553 (1972) [hereinafter Stoebuck]

Mary E. Wooley, Early History of the Colonial Post Office in Proceedings of the RHode IsLand Historical SOCIETy 1892-93 (1893) [hereinafter Wooley]

2 Smith, Wealth, supra note 2, at 469.

3 FinLAY, supra note 1, at 1. The formal appointment apparently was on January 5, 1773.

Steele, Finlay, supra note 1.

4 FinLaY, supra note 1, at 1.

5 Steele, Finlay, supra note 1 (noting "the diligence that marked his entire career"). 
Finlay interviewed postmasters and assessed conditions in every major city and town he visited. His journal, which is still extant, ${ }^{6}$ reports both the strengths and deficiencies of the colonial postal service. ${ }^{7}$ The deficiencies were many: Some local postmasters did not fully understand their jobs. Some had never submitted their accounts. Facilities were frequently poor. The mail was often late, and might be lost or damaged. Post riders disregarded instructions and accepted personal jobs that lined their pockets, but delayed their rounds. Finlay also found outright corruption, as when letter carriers extorted money from recipients for delivering items for which postage had been pre-paid.

One reason for the deficiencies may have been prolonged administrative neglect. Two postmasters general were supposed to oversee the northern half of the system, but one of the two had been Europe for nearly ten years. While largely ignoring his postal responsibilities, he served personal clients and continued to collect his postal salary. The truant's name was Benjamin Franklin.

This narrative of fault in an otherwise-revered American Founder is but one illustration of how inquiry into the Postal Clause offers unusual perspectives on the Constitution, on the framers who wrote it, and on the ratifiers who adopted it.

The Postal Clause itself is distinctive in several ways. It appears to convey two powers: establishing post offices and establishing post roads. Inquiry reveals that it created a single sweeping power: erecting and operating a national transportation, freight, and communication monopoly. Nearly all the Constitution's other enumerated powers - national defense, taxation, regulation of inter-jurisdictional commerce, protection of intellectual property, and so forth-address functions inherently governmental. Delivery of letters and parcels is not quite in the same category. As the modern history of the United Parcel Service and Federal Express demonstrate, private companies in competitive environments can provide nearly universal service. ${ }^{8}$

History before the founding had demonstrated serious defects in the British postal model. Nonetheless, the Founders sought to copy that model in almost all respects, along with its defects; indeed the wording of the Clause follows closely the language of certain British postal statutes. Our justly-celebrated Founders generally favored private enterprise, ${ }^{9}$ but they opted for a government-owned postal system. They railed against monopolies, but they instituted one. They sought to learn from history, but they replicated in America the flawed British postal system.

These decisions seem dysfunctional if we think of the postal system as primarily designed to serve the general public ${ }^{10}$ However, the "public service" rationale for the post office - as way to facilitate democracy and empower citizens - is primarily a product of the nineteenth century, not of the eighteenth. As explained below, the

FINLAY, supra note 1.

See infra notes 220-230 and accompanying text for a description of the deficiencies.

s Serving expensive marginal locations can create a "network advantage" that more than compensates for the additional cost of service. Cf. SHAPIRO, supra note 1, at 2; Metcalf's Law, Business Dictionary, at http://www.businessdictionary.com/definition/Metcalfe-sLaw.html (last visited Feb. 28, 2018).

9 E.g., The Federalist No. 24, supra note 1, at 121 (Alexander Hamilton); id. No. 34, at 164 (Alexander Hamilton) (both assuming that Americans had the goal of being "a commercial people").

10 RoPer, supra note 1, at p. xv ("The mightiest implement of human democracy is postal service. Good postal facilities prompt and encourage the spirit and service of that world democracy which makes for the freedom and happiness of mankind."). 
initial goals of the postal system were to strengthen the federal government, and those in control of the federal government.

\section{B. This Article's StruCture and MEthod}

Part I of this Article examines the prior history of the British imperial postal system, the institution from which the American post office evolved. Part II examines the North American colonial branch of the imperial post, and Part III discusses the American system between Independence and the commencement of operations under the new Constitution. Part IV addresses the debates over the Postal Clause at the Constitutional Convention, and Part V addresses the ratification debates. Part VI contains my conclusions as to the original meaning of the Clause. Part VII offers a glance ahead toward post-ratification history: the effect of the Bill of Rights on the Postal Clause, the significance of the 1792 Post Office Act (including its implications for what later became known as the "non-delegation doctrine"), ${ }^{11}$ and the ignominious dismissal — and subsequent glory — of the last Confederation postmaster, Ebenezer Hazard.

A word about method: When discussing the original meaning of constitutional provisions, legal writers commonly enlist as evidence material arising years, even decades, after the ratification. ${ }^{12}$ This exemplifies the methodological error of anachronism — or, less formally, "reading history backward." The error lies in imputing reliance by the ratifiers on events that hadn't happened yet.

This Article seeks to avoid anachronistic readings by relying almost exclusively on evidence arising before the thirteenth state, Rhode Island, ratified the Constitution on May 29, 1790. Nothing in the Part VII "glance ahead" alters conclusions reached in Part VI.

\section{Background History: The British Imperial Postage System}

\section{A. Why BRITISH PRACTICE IS RELEVANT}

British, and especially English, historical background is always useful in constitutional interpretation. For re-creating the meaning and scope of the Postal Clause, it is compelling.

In 1692, the British government appointed a postmaster general for the colonies, ${ }^{13}$ and from that date the North American post office was a branch of the royal post. ${ }^{14}$ The integration became complete in 1711 — during the reign of Queen

Act. of Feb. 20, 1792, ch. 7, 1 Stat. 232.

12 E.g., District of Columbia v. Heller, 554 U.S. 570, 606-19 (2008) (relying on nineteenthcentury materials in determining the public meaning of the Second Amendment); Baude, supra note 1, at 1751 (relying on "seventy-five years of subsequent practice and precedent" as tending to demonstrate original meaning).

13 JOYCE, supra note 1, at 110.

14 Robinson, supra note 1, at viii ("The Post Office of the United States originated as a colonial extension of the British Post Office ..."). 
Anne-when Parliament enacted legislation "establishing a general Post Office for all Her Majesty's Dominions." 15 The North American postal system became and remained a division of a network that served England, Scotland, Wales, Ireland, the West Indies, and other parts of the British Empire. ${ }^{16}$ The British government thus exercised far more control over the post office in the colonies than it did over most facets of colonial governance.

From 1775, when the Revolutionary War began, until 1790, when the thirteenth state ratified the Constitution, American ideas of what it meant to "establish Post Offices and post Roads"17 remained thoroughly products of British experience. Benjamin Franklin, who more than any other individual was responsible for creating the United States post office, relied on 37 years of personal experience serving the royal post. ${ }^{18}$ Not only did Franklin follow the British model closely, but so did Congress, the Constitution's framers, and the three postmasters general who succeeded Franklin. ${ }^{19}$ Indeed, the very phrase "establish Post Offices and post Roads" was lifted verbatim from a British postal statute. ${ }^{20}$

Independence changed many things, but it did not immediately alter American ideas about the purposes and characteristics of a postal service.

\section{B. THE ENGLISH BEGINNINGS}

The royal post evolved from a network erected in England during the sixteenth century. ${ }^{21}$ Its purposes were not limited to mail delivery ("the poste for the

9 Ann., c. 10 (1711). The British Statutes at Large show the measure as adopted by the parliament called into session on November 25, 1710, 4 STATUTES AT LARge $404 \& 417$ (1786), but the measure did not pass the House of Lords until May 16, 1711. 19 LoRDs J. 298-99 (May 16, 1711).

16 Frustrated by a lack of service from the royal post, the North Carolina colonial assembly authorized a state service on a year to year basis. 5 N.C. RECORDS, supra note 1, at 555 (Oct. 13, 1755); id. at 684 (Oct. 23, 1756); id. at 1101 (Dec. 23, 1758). However, the colonial assembly rejected a permanent establishment, $6 \mathrm{id}$. at 950 (Dec. 8, 1762), in favor of inducing the royal post to serve the colony. E.g., 4 id. at 1341 (Apr. 10, 1752) (reporting bill to "encourage the Postmaster-General to establish a Post Office in this Province"); $6 \mathrm{id}$. at 1242 (Nov. 20, 1764) (reporting a bill for payment of the postmaster general if he provide service in North Carolina); $7 \mathrm{id}$. at 41 (May 2, 1765) (reporting speech by the lieutenant governor calling for the legislature to defray the expense for expansion of the royal post); $i d$. at 54-55 (May 16, 1765) (legislative committee formed to negotiate with the postmaster general); $8 \mathrm{id}$. at 365 (Jan. 17, 1771) ("A Bill to encourage and support the establishment of a Post Office in this Province").

The royal post had arrived in North Carolina by January, 1771. 8 Id. at 430-41 (Jan. 16, 1771) (reproducing a letter from the governor noting extension of service to the state).

17 See infra notes 67-70 and accompanying text for subsequent use in the postal context of the term "establish."

18 Franklin became Philadelphia postmaster in 1737 and colonial postmaster in 1753 . He served until his dismissal in 1774. Roper, supra note 1, at 26-27 \& 35.

Infra Parts III \& V.

20 Infra Part I.C.

21 Robinson, supra note 1, at 7-22; Lewins, supra note 1, at 20-21; HeMMEON, supra note 1, at 4-7; Ogilvie, supra note 1, at 443 (all outlining sixteenth century development) 
pacquet"). ${ }^{22}$ At least as important was the transportation of persons ("the thorough [through] poste"). ${ }^{23}$ During the reign of Queen Elizabeth (1558-1603), there were six great post roads, together serving as the veins and arteries of the system. ${ }^{24}$

In Elizabeth's time private persons could travel over the post roads, but the message-courier service was formally closed to them. Royal agents and couriers delivered letters only on official state business. Foreigners and merchants relied on private networks. ${ }^{25}$ Others sent correspondence however they could. If they knew a royal courier was headed in a particular direction, they might ask him to carry their own letters and packages, either for free or for pay. The government tolerated the practice unofficially, ${ }^{26}$ since it preferred that citizens not resort to private alternatives.

Eventually officials recognized that formally opening the network to private letters and parcels might benefit the government, and during the $1630 \mathrm{~s}$, a postmaster general named Thomas Witherings, did so. ${ }^{27}$ Today, Witherings is recognized as a great innovator, but at the time, some saw him as a troublemaker. He was fired as domestic postmaster in 1637 and as head of the Foreign Letter Office three years later. ${ }^{28}$

From being a system that no correspondent outside the government could use, the royal post became the system correspondents were required to use: After 1637, it was a mail-carrying monopoly. ${ }^{29}$ Only if the royal post did not serve a town could

JoYCE, supra note 1 , at 5.

23 Id. at 5 ("But long after the public had been admitted to the free use of the post, the two objects of providing for letters and providing for travelers continued to be treated as inseparable.").

24 The initial six were (1) the Great North Road, from London to Edinburgh, the capital of Scotland, (2) its extension west from Newcastle to Carlyle, both in northern England, (3) the road from London to Plymouth, which extended west into Cornwall, (4) the road from London to Dover, by which travelers went to the continent, (5) the way from London to Milford in southern Wales, and (6) the way from London to Holyhead in northern Wales. The latter two were the principal routes to Ireland. RoBinson, supra note 1, at 16-21.

For expansion of the postal road network in the seventeenth and eighteenth centuries, see Robinson, supra note 1, at 61 (as of 1675) \& 104 (as of 1756). See also William Owen, Owen's BOOK OF RoAds 40-85 (1777) (listing towns and mileages in England, with post towns in italics); $i d$. at 122-3 (listing certain post roads with mileage between posts).

25 Lewins, supra note 1, at 32; HeMmeOn, supra note 1, at 6-7.

26 Robinson, supra note 1, at 11-12 (stating that carriage of private letters had begun, at least informally, by 1590); JoYCE, supra note 1, at 4 ("even in the reign of Elizabeth letters other than State letters had begun to be sent to the posthouses, and that such letters, if barely recognised, were yet not excluded"); LewINs, supra note 1, at 34 ("During the reign of James none but the despatches of ambassadors were allowed to jostle the Government letters in the leather bags, 'lined with baize or cotton' of 'the post for the packet;' and it was not till towards the end of the reign of his unfortunate son that this post came to be used, under certain conditions, by merchants and private persons.").

27 Robinson, id. at. at 27-33; Lewins, supra note 1, at 38; Joyce, supra note 1, at 18; Hemmeon, supra note 1, at 11-18; Ogilvie, supra note 1, at 444 (all outlining Witherings' reforms). However, Blackstone gave primary credit for the then-existing system to Edmond Prideaux. 1 William Blackstone, Commentaries *311. Prideaux became postmaster general in 1644. HeMmeON, supra note 1, at 20.

28 RoBinson, supra note 1, at 33 \& 37; JoYCE, supra note 1, at 21-22.

29 Lewins, supra note 1 , at 39 . Because this was a time when monopolies were seen as violating natural liberty, there apparently was some public resistance. $I d$. at $40 \& 43$; Ogilvie, supra note 1, at 445. 
private couriers carry letters and packages to and from that town - and only from the nearest post office. Once the government established service in a place, private carriage to and from that place was banned..$^{30}$

\section{Vocabulary and Operations of the British Postal System}

When Elizabeth died in 1603, James VI of Scotland became James I of England as well. In 1707 the two countries submitted to a single Parliament. When speaking of the eighteenth century, therefore, it is appropriate to refer to British rather than English postal institutions.

The British system was based principally on a network of great post roads connecting major cities and towns. During the eighteenth century there were still only six, all radiating from London. The "Great North Road" extended to Edinburgh, the capital of Scotland and the hub of the Scottish post office. ${ }^{31}$ A post road did not derive its name from the mail that traveled over it. A post road derived its name from the fact that it was punctuated by posts.

A post was a station where correspondence and packages were picked up and delivered, tired horses exchanged for fresh ones, tolls collected, and vehicles and guides hired. Either the post itself or the stretch of road between posts could be called a stage..$^{32}$ As the century progressed, officials increasingly supplemented the great post roads with side routes called cross posts or cross stages. They served towns located away from the principal highways. ${ }^{33}$

Each post was overseen by a post-master or post-mistress ${ }^{34}$ who operated a post office..$^{35}$ The government might employ a local postmaster/mistress directly or contract out ("farm") the position. He or she collected tolls, operated a facility for leasing horses and carriages, and often operated an $\mathrm{inn}^{36}$ and/or published a newspaper. Evidence of the consanguinity of posts and newspapers still survives in the names of many British and American journals: the Daily Mail and Yorkshire

309 Ann., c. 10, $\$ 10$ (1711) (imposing postage on letters sent by cross-stages once the stage is completed).

31 Joyce, supra note 1, at 52-53 \& 117-18 (discussing the Scottish post office).

32 Compare Joyce, supra note 1, at 48 ("The post roads were then divided into sections or, as they were commonly called, stages") with Lewins, supra note 1, at 23 ("The route from London to Berwick is shown by the lists of posts (or stages)").

RoBinson, supra note 1, uses the word in both senses. Compare id. at 7 ("the Master of the Posts would divide the road into stages of ten to fifteen or more miles) with id. at 16 ("In 1589 the stages on the road south from Berwick were Berwick, Belford, Alnwick" [and so on, listing stations]).

33 Id. at 65, defines cross post as a route "between post towns on different main roads," but that could be true only of Britain, because in America there was only one main post road. Routing determined whether correspondence was classified as "London letters, country letters, bye or way letters, and cross-post letters." JoYCE, supra note 1, at 147. The 1711 statute used the term cross stage. 9 Ann., c. 10, § 10 (1711).

34 A significant number of women were so employed. JoYCE, supra note 1, at 146 (referring to the postmistress at St. Columb); 159 (referring to the postmistress at Ferrybridge) \& 161 (referring to the postmistress of Lancaster).

35 In 1788 there were 608 post offices in England. JoyCE, supra note 1, at 254.

36 LewINs, supra note 1, at 73 \& 141; JoYCE, supra note 1, at 52. 
Post in England, for example; and the Charleston (S.C.) Gazette-Mail and the Washington Post in America.

Riders picked up and delivered letters and parcels on a (supposedly) regular schedule. An ad hoc rider for delivering a particular letter or package was called an express. ${ }^{37}$ Today we associate the word "express" with speed, but originally the term referred only to the ad hoc nature of the delivery. ${ }^{38}$

Any traveler using a post road-whether an official courier or a private individual — was said to ride post. ${ }^{39}$ In the most popular English-language poem of the $1780 \mathrm{~s},{ }^{40}$ The Diverting History of John Gilpin, William Cowper described how Gilpin lost control of his horse, which tore along the post road from London to points north. Gilpin's wife watched helplessly, as she saw

"Her husband posting down

Into the country far away." ${ }^{11}$

A courier on horseback was called a post rider, a post boy ${ }^{42}$ (although most were full-grown men) ${ }^{43}$ or simply a post. ${ }^{44}$ Grammatically, the noun post in the expression "post haste" is in the vocative case: The sender wrote the expression on the outside of a letter to communicate to the post (rider) the need to deliver the letter quickly. ${ }^{45}$ Post riders had bad reputations for drinking, delays, and corruption, ${ }^{46}$ so if the sender was a person of sufficient importance, he might include a threat: "Haste, post, haste-for your life!" 47

The post boy carried letters in a chest called a portmanteau ${ }^{48}$ or portmantle, ${ }^{49}$ with the letters for each location collected in a bag. The bag was called a mail. This word did not, as today, serve as a synonym for letters in general. To say that

JoYCE, supra note 1, at 63.

Sometimes a mail coach could outpace an express. JoycE, supra note 1, at 233.

E.g., 9 Ann., c. 10 (1711), § 14 (using the term).

40 John D. Baird, Cowper, William (1731-1800), poet and letter-writer, OXFORD DictionARY OF NAT'L BIography (2004-16) (identifying John Gilpin as "the most popular poem of the decade"), available at http://www.oxforddnb.com.weblib.lib.umt.edu:8080/view/ article $/ 6513$ ? docPos $=5$.

41 Cowper, supra note 1, at 194.

425 Geo. 3 , c. 25 (1765), $\S \S 20 \& 21$ (using the term "post boy" to refer to a rider).

43 Lewins, supra note 1 , at 65.

44 Giles Jacob, A New Law-Dictionary (10 $0^{\text {th }}$ ed. 1782) (unpaginated) (defining "post" as "A swift or speedy messenger to carry letters, \&c."); ENCYCLOPAEDIA BRITANNICA, supra note 1, at 6441 (defining "post" as "a courier or letter-carrier; or one who frequently changes horses, posted or placed on the road, for quicker dispatch.").

45 JOYCE, supra note 1, at 19-20.

46 RoBInSON, supra note 1, at 131 (describing post boys as idle and likely in league with mail robbers). See also Lewins, supra note 1, at 65 \& 109 n.1 ("Some of these postboys were sad rogues, who took advantage of the confusion in the two posts in order to do business on their own account, carrying letters concealed upon them, of course for charges quite unorthodox."); JoYCE, supra note 1, at 140 (describing systemic corruption, including but not limited to post boys).

47 Robinson, supra note 1, at $20 \mathrm{n} .18$ (setting forth examples of "post haste" endorsements).

48 John, SpREADING, supra note 1, at 32 (using the term "portmanteau").

49 JOYCE, supra note 1, at 16 (using the term "portmantle"). 
arrangements were made "for the transportation of the several mails" ${ }^{50}$ was to say arrangements were made for delivering the various bags of letters and parcels. Generally each mail was destined for a different location.

In his long poem The Task, Cowper portrayed a post boy trudging his way, blowing his post horn upon arrival, and his indifference to the content of the letters he carried:

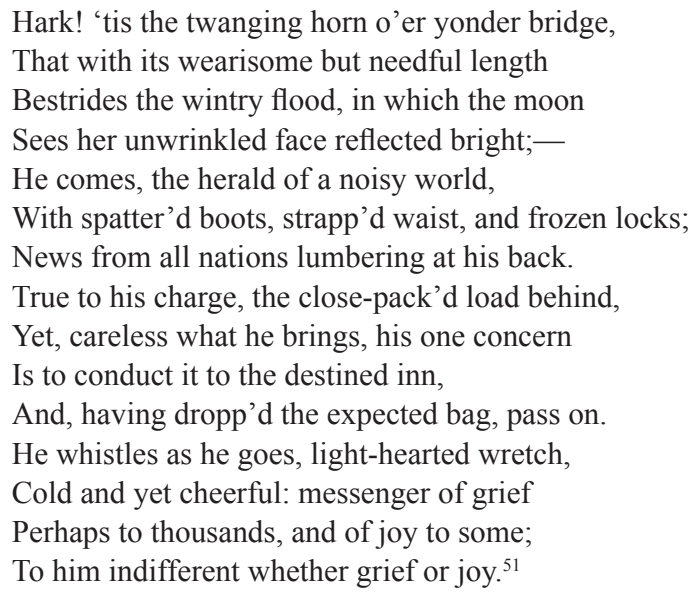

After 1660, and particularly in the eighteenth century, transport in horse-drawn coaches was increasingly available. ${ }^{52}$ Stage coaches or post coaches traveled the post roads from stage to stage.$^{53}$ The post-chaise was a lighter vehicle for post-road travel, and a stage wagon was a heavy vehicle for conveying merchandise. ${ }^{54}$ For service overseas or between British ports, the government commissioned a fleet of packet boats. ${ }^{55}$

The chief executive of the entire system was the postmaster general-the adjective "general" meaning "national" as opposed to "local," as in "general

$50 \quad$ E.g., 28 J. Cont. Cong., supra note 1, at 289 (Jun. 30, 1785). See also 29 J. Cont. ConG., supra note 1, at 525 (Jul. 12, 1785) ("for the transportation of the mails in stage carriages").

51 These lines proceed:

Houses in ashes, and the fall of stocks,

Births, deaths, and marriages, epistles wet

With tears, that trickled down the writer's cheeks

Fast as the periods from his fluent quill,

Or charged with amorous sighs of absent swains,

Or nymphs responsive, equally affect

His horse and him, unconscious of them all.

Cowper, supra note 1, at 75-76 (The Task: Book IV, The Winter Evening, lines 1-22).

52 Robinson, supra note 1, at 68. A kind of stage coach first appeared in London about 1608. LeWINS, supra note 1 , at 74.

53 JOYCE, supra note 1, at 214.

54 Lewins, supra note 1 , at 77.

559 Ann., c. 10, § 9 (1711); LewINs, supra note 1, at 94-96; JoYCE, supra note 1, at 72-109 \& 246-49 (describing the packet service). 
welfare" 56 and "general convention." 57 There were two postmasters general for the Empire, ${ }^{58}$ and they exercised authority jointly. ${ }^{59}$ They "divided their patronage, nominating to vacancies during alternate months, sharing new places, and signing together all appointments." ${ }^{\prime 0}$ Working below them were the "clerks of the road," 61 one deputy postmaster for the American and West Indian colonies from the Carolinas southward, and two deputies for the American colonies from Virginia northward. When Hugh Finlay made his survey in 1773 and 1774, Franklin was one of the latter.

The post road's status as an intercity highway dotted with stations for lodging, eating, renting, and refueling rendered it the founding-era analogue to the modern interstate highway. In Britain, however, the transportation component of the royal post enjoyed monopoly privileges absent from modern interstate highways. For many years it was illegal to rent a horse or carriage for use on a British post road from anyone but the local postmaster or postmistress. Only if he or she could not provide a horse or carriage within a half hour of demand was the traveler free to make his own arrangements. ${ }^{62}$ Moreover when renting a horse or vehicle, travelers were required to hire a postal guide. ${ }^{63}$

The monopoly was weakened in 1749 when certain chaises and calashes, both light vehicles, were exempted from the rental restrictions. ${ }^{64}$ The monopoly was entirely abolished in 1779 , when it was replaced by an expansion of turnpike tolls and licensing. ${ }^{65}$

Thus in 1782, Cowper's John Gilpin was permitted to ride onto the post road mounted on a horse borrowed from a friend rather than leased from the postmaster. Gilpin also avoided paying tolls, because his appearance-dashing at break-neck speed with stoneware bottles flying from his belt-caused the toll gate keepers to think he was running a race:

\footnotetext{
Away went Gilpin—who but he?

His fame soon spread around;

"He carries weight! He rides a race!"

"'Tis for a thousand pound!"

And still, as fast as he drew near,
}

56 E.g., U.S. Const., art. I, § 8, cl. 1.(“The Congress shall have Power To lay and collect Taxes, Duties, Imposts and Excises, to pay the Debts and provide for the Common Defence and general Welfare").

57 Natelson, Conventions, supra note 1, at 629.

58 Robinson, supra note 1 , at 78.

59 ElLIS, supra note 1, at 16.

60 Id. at 18.

${ }^{61}$ JoYCE, supra note 1, at 47. By 1700, there were eight clerks of the roads, but still only six great post roads. Hemmeon, supra note 1, at 27

62 JOYCE, supra note 1, at 130-31; 9 Ann., c. 10 (1711), § 20.

63 When the traveler reached a stage and hired new horses, the guide took the horses back to the stage whence they had come. Joyce, supra note 1, at 30 . Under the 1711 statute, the charge for a horse was three pence per mile and the charge for the guide was four pence per stage. Id. at 130; 9 Ann., c. 10 (1711), § 14. See also Robinson, supra note 1, at $23 \& 48-49$ (describing the transportation monopoly).

6422 Geo. 2, c. 25 (1749).

6519 Geo. 3, c. 51 (1779); 20 Geo. 3, c. 51 (1780). 
'Twas wonderful to view, How in a trice the turnpike-men

Their gates wide open threw. ${ }^{66}$

Thus, by the eighteenth century the royal post was an elaborate carriage and transportation institution. The verb usually employed for erecting such an institution was to establish. The dictionary said that establish denoted "[t]o settle firmly, to fix unalterably; to found, to build firmly, to fix immovably; to make settlement of any inheritance." ${ }^{\prime 67}$ To "establish" a postal network meant to create the entire apparatus, including a complete set of rules for initiating and operating it. ${ }^{68}$ When Parliament decided to expand postal services for the first time to the Isle of Man, it granted the postmaster general the authority to create the island's system from the ground up by empowering him "to establish Post Offices and Post Roads." ${ }^{69}$ In other contexts, the word "establish" could be used for instituting particular ingredients of an existing system, such as posts, packets, and roads. ${ }^{70}$

\section{Purposes of the British Postal System}

Today we think of the British and American post offices as primarily public service institutions and as networks for popular distribution of information. The eighteenth century records disclose some evidence of that mode of thought, particularly among printers campaigning for free or reduced-cost newspaper carriage. ${ }^{71}$ This was not, however, the prevailing rationale for the post office until the nineteenth century. ${ }^{72}$ Its original rationale was to provide a network for travelers and couriers on official business. Government officials soon perceived a need for more: "From the start government was obsessed by the desire to monopolize and control and even limit the communication of the people," writes postal historian Howard Robinson. ${ }^{73}$ Kenneth Ellis, another postal historian, adds:

Throughout the eighteenth century the Post Office circulated propaganda distributed by Country Deputies [i.e., MPs] . . . . Propaganda consisted

66 Cowper, supra note 1, at 191.

67 Thomas Sheridan, A Complete Dictionary of the English Language (2d ed. 1789) (unpaginated) (defining "establish"). The definitions in other dictionaries were similar, e.g., Samuel Johnson, A Dictionary of the English Language ( $8^{\text {th }}$ ed. 1786) (unpaginated) (listing seven definitions, including "To settle firmly; to fix unalterably"); NATHAN Bailey, A Universal Etymological English Dictionary (25 $5^{\text {th }}$ ed. 1783) (unpaginated) ("to make stable, firm and sure, to fix or settle").

68 E.g., 9 Ann., c. 10 (1711) (referring to comprehensive creation and regulation of a postal system as "establishing" it); 4 Geo. 2, c. 33 (1731) (referring to the "Establishment" of the penny post).

697 Geo. 3, c. $50(1767), \S 5$.

70 E.g., Preambl., 9 Ann., c. 10 (1711) (referring to the establishment of individual posts); id. $\S 5$ (referring to post roads "settled and established"); 7 Geo. 3, c. 50 (1767), § 4 ("establish a packet boat").

71 Infra Part V.B.

72 See generally John, Spreading, supra note 1 (focusing on the "public service" theme).

73 Robinson, supra note 1 , at vii. 
of Proclamations, prayers, and notices usually sent as State's Franks, and Gazettes, newspapers, and pamphlets, as Newspaper Franks . . . [W]ith the expansion of the government press in the early eighteenth century, its value greatly increased. Pamphlets, then the best propaganda, were frequently delivered at the office on the government's orders for free distribution by Country Deputies, Customs and Excise officers. Subsidized newspapers, known as Pension Papers, were also circulated to meet the growing demand of gentry, innkeepers, and provincial editors. ${ }^{74}$

The postal system enabled officials to collect as well as distribute communications. By having the post send newspapers to them, officials could monitor activities throughout the country. ${ }^{75}$ The monopoly on letting horses on post roads, together with official records of who was renting what to go whither, facilitated government oversight of travelers. ${ }^{76}$ The monopoly on transmitting correspondence assured that officials could choose to open almost any letter sent from, to, or within Great Britain. ${ }^{77}$

The practice of letter opening diminished somewhat after the accession of William and Mary in $1689,{ }^{78}$ but it did not stop. Some of it was legal: The 1711 postal statute explicitly permitted some letter-opening. ${ }^{79}$ Most of it was illegal. ${ }^{80}$ Targets included the mail of foreign diplomats, hired Hessian soldiers, ${ }^{81}$ and other inhabitants of foreign countries and of Scotland and Ireland. Professor J.C. Hemmeon observes:

74 EluIs, supra note 1, at 47-48.

75 Id. at 61; RoBINSON, supra note 1, at 120; JoYCE, supra note 1, at 7 ("[I]t is a fact beyond all question that the posts in their infancy were regarded and largely employed as an instrument of police. It was not until the reign of William the Third that they began to assume their present shape of a mere channel for the transmission of letters.").

76 Joyce, supra note 1, at 6-7 ("no letter and, except along the bye-roads where posts did not exist, no traveller [ $\mathrm{sic}]$ could pass between one part of the kingdom and another without coming under the observation of the Government.").

77 On monopoly status as facilitating surveillance, see also Ogilvie, supra note 1, at 444.

78 RoBinson, supra note 1, at 45 (stating that during the seventeenth century, "[s] uspected letters were constantly opened."); $i d$. at 54 (discussing a "device for the expert opening and resealing of letters); HeMmeOn, supra note 1, at 21 (discussing the opening of letters under the Commonwealth [1649-60]). See also id. at 47:

We find very few complaints about the opening of letters during the second half of the eighteenth century. On the other hand it must be confessed that letters were at times opened and searched merely to learn the beliefs and plans of political opponents.

However, Professor Ellis' findings tend to show the level of spying in the late eighteenth century was greater than Hemmeon suggests. Infra notes 80 \& 83-86 and accompanying text.

799 Ann., c. 10 (1711), $\S 40$ (authorization for opening mail by warrant of one of the principal secretaries of state).

80 ELLIS, supra note 1, at 60-76.

81 Rodney Atwood, The Hessians: Mercenaries from Hessen-Kassel in the American Revolution 53 (1980) ("[A]ll Hessian personnel were allowed to send letters home without charge provided they were marked 'Bureau General des Postes à London'. This gave the British an opportunity to spy on the mail and check the morale of their auxiliaries."). See also id. at 110. 
[T] he early English postal System was mainly political in its aims. The great post roads were important from a political rather than an economic standpoint. It was necessary to keep in close touch with Scotland because the Scotch would always stand watching. The wild Irish needed a strong hand and it was expedient that English statesmen should be well acquainted with things Irish. The post to and from the continent was quite as necessary to keep them informed of French and Spanish politics. ${ }^{82}$

Other targets were Englishmen whom those in power thought "stood watching." Royal governors in the colonies routinely opened letters coming into their territory. ${ }^{83}$ Private letters to and from political opponents of current cabinet ministers were frequently inspected. ${ }^{84}$ A secret government department - although not actually part of the post office- -was devoted to this activity. ${ }^{85}$ The functionaries in the office were experts in covering up their work:

Security depended on technical skill, restricted knowledge, loyalty, and the absence of parliamentary criticism. As regards the first, a high level of efficiency was maintained, especially in the case of diplomatic correspondence, the seals being carefully engraved, special wax procured, and opening and closing done without trace. Neither time nor trouble were spared, three hours being regularly spent on the King of Prussia's dispatches in mid-century. ${ }^{86}$

Despite the care taken, many people knew, or suspected, that letter-opening was common. Members of Parliament knew ${ }^{87}$ So did other well-connected figures, many of them victims of surveillance. ${ }^{88}$ The list of persons spied upon during the eighteenth century reads like a "Who's Who" of distinguished persons ${ }^{89}$ - Benjamin

\footnotetext{
Hemmeon, supra note 1, at 97-98.

ElLIs, supra note 1, at 64.

Id. at 71-72.

85 Robinson, supra note 1, at 121-25; Ellis, supra note 1, at 67. See also Betty Kemp, Review of Kenneth Ellis, The Post Office in the Eighteenth Century, 73 Eng. HIst. Rev. 726, 727 (1958) (pointing out that the secret office was not part of the postal department).

86 ElLis, supra note 1, at 75-76.

87 JoycE, supra note 1, at 170-71:
}

As early as 1735 members of Parliament had begun to complain that their letters bore evident signs of having been opened at the Post Office . . . . but it was not until six years later ... that the state of the case became fully known. It then transpired that in the Post Office there was a private office, an office independent of the postmasters general and under the immediate direction of the Secretary of State, which was expressly maintained for the purpose of opening and inspecting letters. It was pretended, indeed, that these operations were confined to foreign letters, but as a matter of fact, there was no such restriction. . . . It was in June 1742 that these shameful facts became known, through the report of a committee of the House of Commons .... .

Adelman, supra note 1, at 737 ("Whig leaders had first-hand evidence that their letters were not secure").

89 ELLIS, supra note 1, at 72, lists, among others, Viscount Bolingbroke, a noted Tory leader and theorist; Sir William Pulteney, a wealthy landowner, lawyer and politician; John 
Franklin among them. ${ }^{90}$ Thus, the need for surveillance was a second reason for operating the postal system.

The third reason was revenue, ${ }^{91}$ for which monopoly status heightened the value. $^{92}$ The government collected money from postage on letters and packages (usually paid by recipients rather than senders), ${ }^{93}$ tolls paid at turnpike stations, ${ }^{94}$ proceeds from renting horses and vehicles, ${ }^{95}$ and fees for postal guides. The fourth purpose - one frequently mentioned in British postal statutes ${ }^{96}$ — was to assist trade and commerce. ${ }^{97}$

The relative importance of these four motivations varied over time. Transaction of official business always remained significant, as did revenue. ${ }^{98}$ During the eighteenth century the system's propaganda role declined, ${ }^{99}$ but its surveillance role remained crucial. ${ }^{100}$ With the expansion of commerce, the benefits for trade became weightier.

Carteret, Lord President of the Privy Council; cleric and author William Temple; John Wilkes, Mayor of London and controversial parliamentarian; Lord Rockingham, who, among much other service, became prime minister; the Earl of Shelburne, also prime minister for a time; and Charles James Fox, one of the greatest Whig political figures of the century.

90 Robinson, supra note 1, at 124. Jonathan Swift (dean of St. Patrick's Cathedral in Dublin, and author of Gulliver's Travels) also was aware that his mail was opened, and offered a characteristically humorous response. RoBINSON, supra note 1, at 123.

91 EnCyCLOPAEDIA BRITANNICA, supra note 1, at 6442 ("The duty for the carriage of letters by post in Britain, forms a branch of the Revenue."); 1 William Blackstone, Commentaries *311-312 ("Another very considerable branch of the revenue is . . the post-office, or duty for the carriage of letters."); ElLis, supra note 1, at 2 \& 38-39 (describing the postal system as a source of revenue). See also RoPER, supra note 1, at 11:

From this time [1708] until the opening of the first English railways and the postal reforms of Roland Hill, the British post office was deliberately used by the Government as a means of taxation, with little or no regard for the advantages to be gained by facilitating correspondence among the people.

92 W.T. Laprade, Book Review: Kenneth Ellis, The Post Office in the Eighteenth Century, 16 WM. \& MARY Q. 147, 147-48 (1959) (describing monopoly status as increasing revenue).

93 ELLis, supra note 1, at 38.

94 RoBinson, supra note 1, at 62 (reporting that "the first of a long series of turnpike acts was passed in 1663").

95 Post horse rental apparently represented a significant part of the revenue. LewINS, supra note 1, at 48; JoYCE, supra note 1 , at 52.

96 E.g., Ogilvie, supra note 1, at 446 (quoting from the preamble for the 1660 statute); 9 Ann., c. 10 (1711), § 27 ("and that the People of these Kingdoms may have their Intercourse of Commerce and Trade the better maintained") \& $\S 40$ (reciting the damage to "Trade, Commerce, and Correspondence" from mail tampering); 5 Geo. 3 , c. 25 (1765), § 6 (citing "the Conveniency of Trade and Commerce"); 7 Geo. 3, c. 50 (1767), preamb. \& $\S 4$ (reciting the importance of trade and commerce).

97 JACOB, supra note 1, at 253 ("the Post is of the greatest Consequence in Point of Advice and Intelligence; without which, Trade and Commerce . . . could not in any Degree be rendered so flourishing").

98 Ogilvie, supra note 1 , at $451 \& 453$ (providing charts with eighteenth century and early nineteenth century revenue amounts).

99 ELLIS, supra note 1, at 59.

100 Id. at 60-77. 
Late in the eighteenth century, some Englishmen began to see the postal system as an agent of public service. ${ }^{101}$ This view was encouraged by the free and low cost delivery of newspapers and by the decision in Smith v. Powdich, ${ }^{102}$ in which the court of King's Bench ruled that local postmasters must deliver letters to the residences to which they were addressed, rather than merely holding them at the post office for delivery. ${ }^{103}$ One writer claims that Powdich "in the most deliberate and solemn manner had affirmed this principle ... that the Post Office was to wait upon the people, and not the people upon the Post Office."104 There is little evidence, however, that this opinion was widespread among the people who mattered.

\section{E. The BRitish Post OfFice BeComes Imperial: The Statute of 1711}

The English Parliament adopted comprehensive postal legislation in $1657^{105}$ and $1660,{ }^{106}$ but both enactments suffered from legal irregularities. The 1657 act was passed during the time of Oliver Cromwell, "the usurper." The 1660 act was passed not by Parliament, but by the "Convention Parliament," which had met without royal sanction. ${ }^{107}$ Moreover, those laws applied only to England. In 1707, England and Scotland became the United Kingdom of Great Britain, and the United Kingdom ruled a large overseas empire. Postal legislation was due for an overhaul. ${ }^{108}$

The overhaul came in 1711, during the reign of Queen Anne, in the form of a statute entitled "an Act for establishing a General Post-Office for all Her Majesty's Dominions, and for settling a Weekly Sum out of the Revenues thereof, for the Service of the War, and other Her [sic] Majesty's Occasions." 109 This measure served as the foundation of the imperial postal service for over a century. ${ }^{110}$

It was adopted at the behest of William Lowndes, the secretary of the treasury, ${ }^{111}$ and as its title suggests it was primarily a revenue measure. ${ }^{112}$ The text disclosed the secondary goal of facilitating "Trade and Commerce." ${ }^{\prime 13}$ As the title further indicated,

101 Cf. ElLIS, supra note 1, at 59.

102 (K.B. 1774) 1 Cowp. 182, 98 Eng. Rep. 1033.

103 JoYCE, supra note 1, at 198-202 \& HEMmeON, supra note 1, at 39 (discussing the case).

104 JOYCE, supra note 1, at 202.

105 Robinson, supra note 1, at 46; Hemmeon, supra note 1, at 23-24, 138 \& 195; Joyce, supra note 1, at 27-28; LewINs, supra note 1, at 45-46.

106 Robinson, supra note 1, at 48; Lewins, supra note 1, at 47; Hemmeon, supra note 1, at 25; JoYCE, supra note 1 , at 27-28.

107 This was the first occasion in the Anglo-American political practice of resorting to conventions as substitutes for legislatures. Natelson, Conventions, supra note 1, at 264.

108 Joyce, supra note 1, at 117-27 (describing the conditions promoting the 1711 statute); RoBinson, supra note 1, at 95-96 (same, in a more abbreviated treatment).

1099 Ann., c. 10 (1711).

110 RoBinson, supra note 1, at 98.

111 ElLIS, supra note 1, at 7.

112 Robinson, supra note 1, at 95; 9 Ann., c. 10 (1711), § 2 ("and the Revenue arising by the said Office better improved").

1139 Ann., c. 10 (1711), § 10. See also id. § 13 (exempting certain merchants' papers from postage); $\S 15$ (imposing rules on ship masters to protect "Merchants and others"); $\S$ 27 ("and that the People of these Kingdoms may have their Intercourse of Commerce and Trade the better maintained"); $\S 40$ (reciting the damage to "Trade, Commerce, and Correspondence" from mail tampering). 
the measure applied to the entire empire, including British North America. ${ }^{114}$ In addition to specifying disposition of post office revenue, the 1711 act-

- authorized chief letter offices in Edinburgh, Dublin, and New York, ${ }^{115}$ and granted the postmaster general authority to constitute certain other offices and appoint personnel to run them; ${ }^{116}$

- reaffirmed the monopoly in carrying letters, packets, and parcels, with delineated exceptions, ${ }^{117}$

- mandated service on certain routes; ${ }^{118}$

- provided for a monopoly in letting post horses and associated "furniture" (saddles, carriages, etc.) within Great Britain and Ireland;"119

- specified in detail the levels of postage for letters and "other Things of greater Bulk" and for rental of horses and vehicles; ${ }^{120}$ postage for heavier items was calculated by weight, without any weight limit except that luggage for travelers was limited to eighty pounds avoirdupois, ${ }^{121}$

- authorized the postmaster general to operate a fleet of packet boats, ${ }^{122}$ erect cross-stages, ${ }^{123}$ and measure the post roads; $;{ }^{124}$

- laid down rules governing letters to and from overseas; ${ }^{125}$

- defined offenses against the post office, listed their punishments, ${ }^{126}$ and identified the courts in which they were to be prosecuted and the causes of action for the purpose; ${ }^{127}$

- prescribed oaths for post office personnel; ${ }^{128}$

- authorized the king or queen to fix further regulations; ${ }^{129}$

- regulated ferry men in North America and imposed mandates on them; ${ }^{130}$ and

- disqualified postal personnel from parliamentary politics. ${ }^{131}$

1149 Ann., c. 10 (1711), §2 (establishing a general post office for Great Britain, Ireland, and British colonies in North America and the West Indies).

1159 Ann., c. 10 (1711), § 4.

116 Id. $\S 4$.

$117 \quad I d . \S \S 2,3 \& 17$ (creating a monopoly for letter and packet delivery and specifying exceptions); see also $\S 6$ (setting rates for letters, packets, and parcels), $\$ 7$ (providing for overseas carriage of letters, packets, and parcels), $\S 13$ (enumerating exceptions), $\S$ 22 (providing exception).

$118 \quad I d . \S 26$.

$119 \quad I d . \S 5$ \& 17 (creating hiring monopoly).

120 Id. $\S 6,8 \& 14$.

121 Id. $\$ 14$.

122 Id. $\S 9$.

123 Id. $\$ 10$.

$124 \quad I d . \S \S 11 \& 12$.

${ }^{25}$ Id. $\S 15 \& 16$.

126 E.g., id. § 17 (prescribing punishment for illegal carriage), § 18 (punishment for mailtampering), § 21 (prescribing punishment for negligent postal personnel); $§ 40$ ("wilfully opening, imbezzling, detaining and delaying of Letters or Packets").

127 Id. $\S 19 \& \S 30$.

128 Id. $\$ 25 \& 41$.

129 Id. $\$ 27$.

$130 \quad I d . \S 29$.

$131 \quad I d . \S 44$. 
Thus, the statutory title's reference to "establishing a General Post-Office" signified creating an entire postal system, with all its elements.

During the period between this statute's passage and the Constitution's ratification, Parliament supplemented the measure several times. ${ }^{132}$

\section{F. Motifs in the DeVElopment of the Imperial Postal System}

Several persistent motifs characterized the history of the royal post before the American Revolution erupted in 1775. These motifs were (1) proliferation of post roads and routes, (2) the post office's enjoyment of significant legal privileges, (3) proliferation of private privileges against the post office, in tension with the revenue-raising goal, and (4) sporadic progress in methods and technology.

The expansion in the number of post roads and routes was certainly impressive. By 1737, treatise writer Giles Jacob could report that the "Conveyance of PostLetters extends to every considerable Market-Town." 133 By 1775, the number of post roads had grown from the initial six into a spider's web covering England and extending to Edinburgh. ${ }^{134}$

The royal post enjoyed various legal privileges denied to private enterprise. One was the carriage and transportation monopoly. Others were exemptions from otherwise-general legal duties. Thus, postal couriers were exempt from the tolls that everyone else paid, ${ }^{135}$ and postal employees were exempt from jury and militia duty. ${ }^{136}$ Still another sort of privilege consisted of legal mandates imposed on outsiders for the benefit of the postal service. For example, Parliament required private ship masters to assist the post office in various ways. ${ }^{137}$ When private operators were finally

1326 Geo. 1, c. $21 \S 51$ (1719) (clarifying postage rates on merchants' documents); 4 Geo. 2, c. 33 (1731) (clarifying charges for delivery by penny post); 22 Geo. 2, c. 25 (1749) (exempting chaises and calashes from the exclusive hiring rule); 26 Geo. 2, cc. 7 \& 8 (1753) (clarifying postage rates on legal writs and clothing patterns); 4 Geo. 3, c. 24 (1764) (curbing the practice of franking); 5 Geo. 3, c. 25 (1765) (altering rates of postage and adopting other reforms); 7 Geo. 3, c. 50 (1767) (extending service to the Isle of Man); 19 Geo. 3, c. 51 (1779) (licensing horse rental and eliminating monopoly); 20 Geo. 3., c 51 (1780) (replacing 1779 statute); 22 Geo. 3, c. 70 (1782) (expanding the frank) \& 23 Geo. 3 ., c. 69 (1783) (expanding the frank); 25 Geo. 3. c. 51 (1785) (a rental licensing and toll law)

133 J $\mathrm{ACOB}$, supra note 1 , at 263.

134 Compare Robinson, supra note 1, at 17 (showing a postal map from Elizabethan times), with id. at 61 (1675 map) and 104 (1756 map). Even the latest map shows only a single post road entering Scotland and ending at Edinburgh.

13525 Geo. 3, c. 57 (1785) (exempting carriages and horses carrying mail from all tolls); LEWINS, supra note 1, at 140-41 (discussing the exemption and its effects).

136 Hemmeon, supra note 1 , at 9; Lewin, supra note 1 , at $47 \& 62$. American deputy postmasters were supposed to enjoy such exemptions as well, but administrative problems sometimes prevented American postmasters from obtaining them. FinLAY, supra note 1, at 33 (describing one case).

137 E.g., 9 Ann., c. 10 (1711), $\$ 16$ (requirement that ship masters deliver letters to the post office) \& $\S 24$ (restrictions on nationality of ships and seamen), explained in $\mathrm{J}_{\mathrm{ACOB}}$, supra note 1, at 255 ("If the Mail be carried out of England in any Vessel not English built, and navigated with English Seamen, the Postmaster-General shall forfeit 100 1."). See also 3 Geo. 3, c. $25, \S 3$ (1765) (providing that arriving ships may not "break bulk" until letters are delivered to the post office). 
allowed to rent horses and vehicles for post-road travel, Parliament exacted license fees and other duties. ${ }^{138}$ Mandates on American ferry men were particularly onerous. They were required to carry the mail on demand, and without compensation. ${ }^{139}$

While granting the postal system special privileges against the public, Parliament granted individuals and institutions privileges against the postal system. The third motif was the conflict between these privileges and revenueraising objectives. The 1711 statute exempted England's two universities, Oxford and Cambridge, from the postal monopoly. Students, professors, and staff could send letters any way they wished. ${ }^{140}$ Politicians diverted a significant amount of revenue to private parties, as when they used postal funds to pay one of Charles II's mistresses the enormous pension of $£ 4700$ annually. ${ }^{141}$ The government provided secret mail-opening services to the politically-powerful. ${ }^{142}$ Of course, the post office also was a source of patronage - although during the eighteenth century patronage does not seem to have greatly impaired worker quality. ${ }^{143}$

A particularly costly privilege was franking. The frank exempted many people from paying postage at all, ${ }^{144}$ even for carriage of very large items. ${ }^{145}$ Each chamber of Parliament demanded the frank for its own members as the price of passing the 1711 statute, ${ }^{146}$ and the statute extended the privilege to other government functionaries as well. The frank was widely abused, to the great injury of the revenue. ${ }^{147}$

Parliament periodically expanded ${ }^{148}$ and contracted ${ }^{149}$ the scope of the frank. The statutes expanding it attained their objective, but it is unclear whether those attempting to contract it did so successfully. The leading effort at contraction was a 1764 measure that one historian claims rendered the situation worse, ${ }^{150}$ but another argues reduced a $£ 170,000$ annual leakage by $£ 30,000 .{ }^{151}$

138 E.g., 25 Geo. 3. c. 51 (1785) (requiring licensing of those letting horses and equipment for riding post).

1399 Ann., c. 10 (1711), § 29.

140 Ogilvie, supra note 1, at 449; 9 Ann., c. 10 (1711), § 32.

141 Robinson, supra note 1, at 53. See also id. at 79 (reporting continued payment of this pension to her and her successors until the government purchased it in 1856).

142 Supra notes 79-80 and accompanying text.

143 ELLIS, supra note 1, at 46 (stating that the "defects lay in the postal system rather than the staff').

144 RoBINSON, supra note 1, at 113-19 (discussing franking).

145 LEWINS, supra note 1, at 96 (listing large franked items).

146 Id. at 97 (stating that the Lords initially rejected the measure because it contained no provision for their franking; after the bill was amended to permit them to frank, they passed it).

147 JoYCE, supra note 1, at 132-35.

1485 Geo. 3, c. 25 (1765), $\S 26$ (extending the privilege) 22 Geo. 3, c. 70 (1782) (same) \& 23 Geo. 3, c. 69 (1783) (same).

149 E.g., 4 Geo. 3, c. 24 (1764); Robinson, supra note 1, at 116-19 (discussing the 1764 law and its aftermath); Ellis, supra note 1, at 41 (discussing the law); RoBINSON, supra note 1, at 152-153 (discussing other efforts to curb franking). See also 24 Geo. 3., c. 37 (1784) (delineating franking requirements); ElLIS, supra note 1, at 42 (discussing the 1784 statute).

150 JoYCE, supra note 1 , at 188. This measure was adopted in the Parliament beginning in 1763, but the journal of the House of Lords shows that it was finally passed on April 16, 1764. 30 Lords J. 578 (Apr. 16, 1764).

151 Ogilvie, supra note 1, at 451. 
Newspaper publishers and printers (generally the same people) received special privileges. Their papers passed free or at very low cost. ${ }^{152}$ The printers were not necessarily grateful. They frequently sent their publications in clumsily-folded conditions with the ink still wet, thereby defacing the letters with which their papers were bundled. ${ }^{153}$

The privilege afforded newspapers can be seen as a laudable exercise of public spirit, for it facilitated dissemination of information, ${ }^{154}$ but more than public spirit lay behind it. Newspapers were vehicles by which members of Parliament distributed propaganda, ${ }^{155}$ and officials tapped newspaper traffic - as well as other matter sent by post - to gather intelligence for government use. ${ }^{156}$

A fourth motif in British post office history pertains to its progress (and nonprogress) in methods and technology. In competitivemarkets, efficiency improvements occasionally burst in with leaps and bounds, but far more often they crawl in. That is, improvements occur in small increments, identified by participants who operate under strong incentives to seek even marginal ways of doing things better. However, a state owned enterprise with monopoly privileges offers few incentives for such vigilance. The methods and technology of the royal post typically stagnated until a zealous reformer, usually an outsider, found a way to force change. ${ }^{157}$

There are many illustrations of this motif. One of the most cited is the episode of Thomas Dockwra's "penny post" of 1680.

Before Dockwra arrived on the scene, the royal post carried letters to cities and towns throughout England, but although headquartered in London it offered no service within London. When the London Common Council tried to fill the gap with its own courier operations, Parliament quickly suppressed them. ${ }^{158}$

In 1680 Dockwra created a new company called the "penny post" to serve the capital city and its suburbs. ${ }^{159}$ His service proved highly popular because it

152 Robinson, supra note 1, at 147. For this, William Cowper was grateful. Once the post boy delivered the newspaper on a winter evening, Cowper settled down comfortably:

This folio of four pages, happy work!

Which not even critics criticise, that holds

Inquisitive attention while I read

Fast bound in chains of silence, which the fair,

Though eloquent themselves, yet fear to break,

What is it but a map of busy life,

Its fluctuations and its vast concerns?

The Task, Book IV, lines 50-56, CowPER, supra note 1, at 76. "The fair" is Cowper's common appellation for womankind.

153 JoycE, supra note 1, at 262. John Palmer seems to have corrected the packaging problem. Id.

154 Robinson, supra note 1, at 147-49.

155 Supra notes $73 \& 74$ and accompanying text.

156 Supra notes 75-90 and accompanying text.

157 Judith Blow Williams, Book Review: The British Post Office: A History. By Howard Robinson, 21 J. Modern Hist. 141, 142 (1949) ("[T] he stimulus for change came usually from persistent criticism from without the regular organization of the post office."); RoBINSON, supra note 1, at vii ("Again and again reformers labored to speed up a slowly evolving government department.").

158 JOYCE, supra note 1, at 24-25.

159 Robinson, supra note 1, at 70-76 (discussing Dockwra's penny post). See also Joyce, supra note 1, at 36-40; HeMmeon, supra note 1, at 28; Ogilvie, supra note 1, at 447-48. 
responded to an unmet need and was otherwise superior to the royal post office in almost every respect. ${ }^{160}$

At that time, the principal beneficiary of revenue from the royal post was the Duke of York, the future James II. ${ }^{161}$ As long as Dockwra was incurring the financial losses characteristic of most start-up companies, the Duke did not interfere. When Dockwra began to make a profit, ${ }^{162}$ the Duke slammed him with twenty separate lawsuits for breaching the postal monopoly. Although Dockwra wasn't exactly competing with the royal post - merely serving routes it did not serve- the courts put him out of business. ${ }^{163}$ The government carried off the spoils, absorbing the penny post into its own network.

After the 1688 Revolution had evicted James II, the government partially compensated Dockwra with a pension and a short-lived job as penny post administrator. ${ }^{164}$

Other entrepreneurs rose to challenge the postal monopoly, each to be suppressed in turn. The government's motives for crushing them were not wholly financial:

[In 1683] the panic caused by the discovery of the Rye-House Plot had led to the issue of a Proclamation which, if differing little from others that had gone before, acquires importance from the circumstances under which it appeared. Unauthorised posts had again sprung up in all directions, simply, no doubt, because there was a demand for the accommodation they afforded; but the Government, no less than the persons who denounced Dockwra's undertaking as a Popish contrivance, seem to have been possessed with the idea that these posts were mere vehicles for the propagation of treason. To prevent treasonable correspondence was the avowed object of the present Proclamation, and the means by which the object was sought to be attained was the suppression of private and irregular posts, for by these, the Proclamation went on to declare, the conspirators had been materially assisted in their designs. ${ }^{165}$

The Rye House plot was long gone when, in 1708, another entrepreneur, Charles Povey, created a "half penny post" for London. The government prosecuted him and destroyed his enterprise. ${ }^{166}$ Again it carried away the spoils, including Povey's innovation of couriers ringing bells to announce their arrival at the post office. ${ }^{167}$

160 For example, Dockwra perfected the institution of the post mark. HEMmEon, supra note 1 , at 29.

161 The Duke acquired this benefit in 1675, while his brother, Charles II, was still king. See JACOB, supra note 1, at 256 ("By 15 Car. 2, "All the Profits . . were settled upon James Duke of York."); LEWINS, supra note 1, at 52.

162 LEWINS, supra note 1, at 55 ("No sooner, however, was that success apparent, and it was known that the speculation was becoming lucrative to its originator, than the Duke of York, by virtue of the settlement made to him, complained of it as an infraction of his monopoly."). Accord: Hemmeon, supra note 1, at 30.

163 Robinson, supra note 1, at 74.

164 LeWINS, supra note 1, at 55. Dockwra was dismissed in 1700. HeMmEON, supra note 1, at 30.

165 JoYCE, supra note 1, at 43.

166 RoBInSON, supra note 1, at 87-88; LEWINS, supra note 1, at 82-84; JoYCE, supra note 1, at 121-23; Hemmeon, supra note 1, at 197.

167 Robinson, supra note 1, at 88; JoyCE, supra note 1, at 123. 
Other challenges arose after the rate increases in the statute of $1711 .{ }^{168}$ In 1719 , an adaptable outsider decided that "crony capitalism" might be a better way to get rich than direct competition. Ralph Allen ${ }^{169}$ offered to pay the government a fixed annual sum in exchange for the exclusive privilege of extending cross posts to unserved areas. Allen incurred losses for years, but was ultimately successful and died wealthy. He became a towering figure in British postal affairs without ever holding an official position in the inland office. ${ }^{170}$

John Palmer was another who successfully negotiated the route to lucrative crony capitalism. As is important for crony capitalists, Palmer was well connected: He had a friend in the younger William Pitt, then prime minister. Palmer convinced Pitt to allow him to contract for letter delivery on major routes using coaches rather than riders. Despite stubborn bureaucratic resistance, ${ }^{171}$ the idea was a decided success. Palmer made a great deal of money. ${ }^{172}$

After Palmer's reforms, post boys drove coaches as well as rode horseback, as illustrated in Cowper's poetic account of the vicissitudes of John Gilpin. In Cowper's poem, Mrs. Gilpin offered the post boy a half-crown to pursue her husband and bring him back safely. The post boy had been driving a post-chaise. He uncoupled one of the horses, swung onto its back, and headed after Mr. Gilpin:

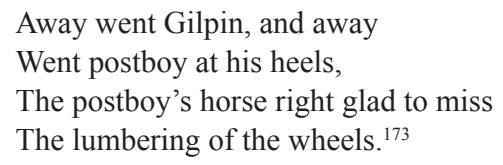

But unlike this post boy's horse, British postal institutions advanced only by fits and starts. In some instances, the office wielded government power to shatter competitors, enabling it to scavenge among the debris. In other cases, innovators wielded the government power against the post office, compelling it to reform.

\section{Background History: The Colonial American Postal System}

\section{A. The American Post Office as the Successor to the British Imperial Post OFFICE}

Until 1775, the American postal network operated under the aegis of the Crown. From 1775 to March 1, 1781 it functioned under the Continental Congress and

\footnotetext{
168 JoYCE, supra note 1, at 133-34.

169 Lewins, supra note 1, at 105-09; JoYCE, supra note 1, at 146-86; RoBInSON, supra note 1, at 99-112; Hemmeon, supra note 1, at 36-39; Roper, supra note 1, at 11 (all discussing Allen's career). See also Ogilvie, supra note 1, at 452 (outlining Allen's reforms).

170 RoBinson, supra note 1, at 106.

171 Id. at 69 \& 134-36.

172 RoBINSON, supra note 1, at 126-40; LeWINS, supra note 1, at 123-36; JoYCE, supra note 1, at 208-13; HeMmeOn, supra note 1, at 40-42; Roper, supra note 1, at 12; Ogilvie, supra note 1, at 452 (all discussing Palmer's career).

173 Cowper, supra note 1, at 194.
} 
from the latter date until April 1789 (when the new government began operations) under the Confederation Congress. Throughout those years the post office remained essentially the same institution. ${ }^{174}$ Knowledge of this continuity is a key to understanding the full meaning of the constitutional phrase "to establish Post Offices and post Roads." Knowledge of this continuity is also a key to understanding ratification-era postal controversy, why citizens demanded a Bill of Rights, and why that Bill included protections from searches and seizures and for freedom of press and speech.

The seventeenth century witnessed scattered efforts to create an indigenous American postal service, ${ }^{175}$ complete with post-road travel monopolies. ${ }^{176}$ If those efforts had been successful, perhaps the eighteenth-century American post office would not have become a mere branch of the British system. Nothing much did come of them, however; and they were superseded by the appointment, on February 7, 1692 (1691, old style), ${ }^{177}$ of Thomas Neal as postmaster general for the colonies. ${ }^{178}$ The post office in America would be directed from London.

Neal remained in Britain, but designated Andrew Hamilton as his man on location. Hamilton was an energetic Scottish merchant and a former lieutenant governor and future governor of New Jersey. ${ }^{179}$ In creating postal institutions he was forced to depend on the cooperation of the colonial assemblies, some of which passed facilitating legislation. ${ }^{180}$ Postal rates had to be negotiated separately with

174 John, Spreading, supra note 1, at 25 states the same idea another way:

Prior to 1792, the American postal system remained constrained by the assumptions that had shaped royal policy ... In the seventeen-year period between 1775 and 1792, the American postal system was little more than a mirror image of the royal postal system for British North America as it had existed in the period prior to 1775 .

As explained in Part VII.B the situation did not change radically even in 1792.

175 Wooley, supra note 1, probably remains the leading study of pre-1711 American postal matters. She begins with the practice of employing Indians as messengers and details the unsuccessful efforts to create an inter-colonial service. Id. at 270-74. See also RicH, supra note 1, at 1-8; LEECH, supra note 1, at 7-8 (describing those efforts).

176 Wooley, supra note 1, at 276-77 (describing New York legislation creating a horse and "furniture" rental monopoly on the post road), 286 (describing a Pennsylvania law providing for rental of horses to travelers), 289 (describing a New Jersey law banning private renting of "horses or furniture").

177 In 1751, Parliament converted from the Julian to the Gregorian calendar. Effective January 1, 1752, Parliament changed the beginning of the year from March 25 to January 1. It also provided that the day after September 2, 1752 would be designated as September 14. This reform applied to the entire British Empire, including the American colonies. 24 Geo. 2, c.23 (1751). The change explains why the English Declaration of Right, promulgated during the Glorious Revolution of 1688, frequently is dated 1689. The Declaration was delivered to William and Mary on February 13, 1688 "old style," which was February 25, 1689 "new style."

178 Wooley, supra note 1, at 275; ROPER, supra note 1, at 20.

179 Id. at 275; Rich, supra note 1, at 14. See Louise P. Kellogg, The American Colonial Charter 235, 239-40 (Washington: Government Printing Office 1904) (stating that Hamilton served as lieutenant governor under the Andros administration and later served as a competent governor).

180 Wooley, supra note 1, at 276-90 (outlining colonial legislation); RicH, supra note 1, at 14-16. See also ROPER, supra note 1, at 21 (claiming that "After much negotiation [Hamilton] succeeded in inducing practically all the colonial assemblies to pass postal 
each colonial government. ${ }^{181}$ By 1698, Hamilton had established posts running once a week from Boston to Newcastle, Pennsylvania. ${ }^{182}$

Parliament's 1711 statute completed the process of pulling the American postal system under the same umbrella that covered England, Wales, Scotland, Ireland, and the British West Indies. ${ }^{183}$ This statute enabled British-designated postmasters to extend the inter-colonial service far beyond the achievements of Andrew Hamilton. When Hugh Finlay came to America, the colonial post office had been an integral part of the imperial system for a lifetime.

\section{B. American Colonial Operations and Ben FranKLIN}

The 1711 statute created a central post office in New York City to govern operations in North America. ${ }^{184}$ By 1764, Britain had acquired Canada and Florida, and in that year the North American territories were split into the districts referred to earlier. ${ }^{185}$ Two deputies were assigned to the northern district and one to the southern; their respective headquarters were New York and Charleston. ${ }^{186}$

In Virginia there was resistance to the notion that Parliament, rather than local assemblies, could set the postal rates. Some Virginians saw these charges as a form of taxation. ${ }^{187}$ The furor eventually faded, but classification of postal rates remained a sensitive issue. When testifying before the House of Commons in 1766, Franklin danced around that issue, characterizing postage as a fee-for-service rather than as a tax. ${ }^{188}$ During the 1770 s, the colonists again protested postage as an unconstitutional "internal tax." 189

In 1737, Franklin became postmaster in Philadelphia, and in 1753, jointly with William Hunter, deputy for the colonies ${ }^{190} \mathrm{He}$ had sought both jobs, ${ }^{191}$ allured partly by the benefits they would offer his newspaper business. ${ }^{192}$ Franklin made significant improvements and helped to put the colonial network on a sound financial basis. ${ }^{193}$ Most writers have ranked him as the colonies' best postal administrator. ${ }^{194}$ When

acts that were sufficiently identical in their terms to permit the establishment of a united system of posts in America.").

181 Smith, supra note 1, at 267; Rich, supra note 1, at 14.

182 JoYCE, supra note 1, at 111.

1839 Ann., c. 10, § 2 (1711).

184 Id. $\S 4$ (1711).

185 Rich, supra note 1, at 39.

186 Smith, supra note 1, at 272-73.

187 Id. at 268; JAFFe, supra note 1, at 38-39.

188 RicH, supra note 1 , at 41.

189 Adelman, supra note 1 , at 730 \& 735-36.

190 LEECH, supra note 1 , at 8.

191 JAFFE, supra note 1, at 39-40 (reporting that Franklin sought the Philadelphia position); RICH, supra note 1, at 29-32 (reporting that he sought the deputy postmaster general position).

192 JAFFe, supra note 1, at 39-40; Rich, supra note 1, at 30.

193 RicH, supra note 1, at 37-38; Smith, supra note 1, at 270.

194 E.g., Smith, supra note 1, at 270 ("The line of undistinguished administrators of the postoffice in America came to an end in 1753 when Benjamin Franklin was made deputy postmaster-general jointly with William Hunter of Virginia."); JAFFE, supra note 1, at 3943 (outlining his accomplishments). See also RoPER, supra note 1, at 35-36; HolBrooK, supra note 1 , at 6-8. 
the colonies were divided into two districts, Franklin became deputy postmaster for the northern region along with John Foxcroft. ${ }^{195}$

Franklin's early contributions were admirable, but the fact remains that he was absent for 15 of his 21 years as deputy postmaster general, and this absent period included virtually the entire time he headed the northern district. ${ }^{196}$ Some of the deficiencies Hugh Finlay observed may have resulted from his absence. It certainly is possible that Foxcroft found the far-flung and relatively populous northern district too much for one person to handle. It is interesting that Foxcroft was the person who asked Finlay to undertake his inspection. ${ }^{197}$ This raises the question of why a postmaster would encourage an inspector to identify deficiencies in the postmaster's own bailiwick. Perhaps Foxcroft was building a case against Franklin. Whether or not this was true, Franklin was dismissed on January 31, 1774 ${ }^{198}$ - at least partly, ${ }^{199}$ but perhaps not entirely — on political grounds. The man appointed to replace him was Finlay. ${ }^{200}$

\section{The American Postal System in the Sunset of British Rule}

In Finlay's time the American postal system centered on a single post road extending from Falmouth, Massachusetts (now Portland, Maine) ${ }^{201}$ to Savannah, Georgia. The 2000 miles of post road ${ }^{202}$ were nearly all within the main artery, for there were very few cross-posts - although the main post road divided into three branches through much of New England. ${ }^{203}$

The southernmost post office in the northern district was Suffolk, Virginia. The northernmost post office in the southern district was Edenton, North Carolina. ${ }^{204}$ They were supposed to coordinate the transfer of mails between them, but Finlay "suspected some mismanagement at the Junction of the Northern and the Southern district." 205

I have not been able to determine with certainty how many post offices then served the thirteen colonies. Finlay's journal does not provide a complete list:

195 Rich, supra note 1, at 39.

196 Smith, supra note 1, at 270 n.42 (observing that Franklin was in England from 1757 to 1762 and again from 1764 to his dismissal in 1774).

197 FinLAY, supra note 1, at 1.

198 ROPER, supra note 1 , at 35 .

199 LEECH, supra note 1, at 8; Adelman, supra note 1, at 736-37. The fact that Franklin was dismissed in January, 1774, before Finlay had a chance to finish his inspection, reduces, but does not eliminate, the chances that it was related to his non-performance. Foxcroft asked for the survey in April, 1773. FinLAY, supra note 1, at 1.

200 Steele, Finlay, supra note 1.

201 FinlaY, supra note 1, at 14.

202 LEECH, supra note 1, at 11.

203 These were the upper, middle, and lower sections. HoLBRooK, supra note 1, at 30; Richard DeLuca, Boston Post Road Carved out Three Travel Routes through State, Connecticut History.org at http://connecticuthistory.org/boston-post-road-carved-out-three-earlytravel-routes-through-state/. The map in Adelman, supra note 1, at 721, omits part of the upper and middle sections.

205 Id. at 73. 
His expedition was interrupted by his appointment as joint deputy postmaster general, ${ }^{206}$ and perhaps by unsettled pre-revolutionary conditions. ${ }^{207}$ Thus, his journal fails to mention post offices in Delaware, New Jersey, Pennsylvania (other than Philadelphia), or Maryland (other than Baltimore). The journal's total count, if I read it right, is $36 .{ }^{208}$ However, in 1788 , a scant fourteen years later, there were 69. ${ }^{209}$ The latter figure, and the fact that Finlay omitted offices in several states, suggests that the number of offices at the close of the colonial era may have been in the neighborhood of 60 .

As in Britain, postmasters often were newspaper publishers. ${ }^{210}$ As in Britain also, post roads were those served by stations ("posts") offering shelter, food, and drink for man and beast and amenities such as newspapers. In some ways, however, the system on this side of the water was less complete than that in Britain. Finlay noted the absence of post horns ${ }^{211}$ and widespread disregard of the requirement that arriving ship masters carry letters entrusted to them to the post office. ${ }^{212} \mathrm{He}$ heard many complaints about the relative insecurity of the mail. ${ }^{213}$

Regulation of travelers was less thorough than in Britain. Efforts to establish transportation monopolies in some colonies ${ }^{214}$ apparently had not taken hold, and Parliament's 1711 statute exempted North America from the rules applied to personal post-road travel in the mother country. ${ }^{215}$ Yet Americans recognized that the system included transportation components. Post riders were required to act as travelers' guides when so requested, ${ }^{216}$ and the taverns at stages along the post road were for travelers as well as for mail couriers.

The colonies north of Maryland were far more densely populated than those to the south. There were post offices every twelve to fifty miles in the North, each supervised by a deputy postmaster. The South had but a handful. Much of the southern post road ran through "Pine, Sand, and Swamp," and was difficult

206 Steele, Finlay, supra note 1.

207 Accord: Hugh Finlay (1731-1801), Smithsonian National Postal Museum, http:// postalmuseum.si.edu/outofthemails/finlay.html (last visited Feb. 28, 2018) ("Finlay's expedition came to an end in June 1774 when growing unrest in the northern colonies made the job of surveying the roads hazardous and, in some cases, impossible.").

208 Only six post offices were in the three southernmost states: one in Georgia (Savannah), two in South Carolina (Charles Town and Georgetown), and three in North Carolina (Wilmington, New Bern, and Edenton). By contrast, Finlay visited, or made reference to, eighteen in the four New England states.

20934 J. Cont. Cong., supra note 1, at 462 (Aug. 27, 1788).

$210 \mathrm{~J}$ AFFE, supra note 1, at 36; e.g., FinLAY, supra note 1, at 30 (noting that the Providence postmaster was also a printer).

211 FinlaY, supra note 1, at 30. See https://www.youtube.com/watch?v=0twzFyFEQrM (featuring post horn design and fanfare). However, there had been post horns in Massachusetts at the beginning of the eighteenth century. Wooley, supra note 1, at 29091 (quoting from a letter referring to them).

212 FinLAY, supra note 1 , at 56 \& 92-93.

213 Id. at 73.

214 Wooley, supra note 1, at 276-77 (describing New York legislation creating a horse and "furniture" rental monopoly on the post road); 286 (describing a Pennsylvania law providing for rental of horses to travelers); 289 (describing a New Jersey law banning private renting of "horses or furniture").

2159 Ann., c. 10 (1711), § 5.

216 HolbrooK, supra note 1, at 21. 
of passage. ${ }^{217}$ The traveler had to cross expansive rivers and inlets that invaded the continent from the sea. Finlay wrote that because of the width of these bodies of water, the mandates imposed on North American ferry men by the 1711 statute made little sense. ${ }^{218}$

Finlay found that while American deputy postmasters generally were conscientious, ${ }^{219}$ they often lacked such basic amenities as credentials. ${ }^{220}$ Their monopoly was continually breached. Private carriers abounded, ${ }^{221}$ and there were even a few private post offices. ${ }^{222}$ Postal riders negotiated to carry letters and other items for their own profit, outside their postal contracts. ${ }^{223}$ Portmantles might be filled with "bundles, packages, boxes, canisters" carried for the profit of the post rider, but often damaging to legitimate mail. ${ }^{224}$ Finlay complained of riders who contracted to drive oxen along the post road $^{225}$ and of riders who demanded money from the recipients for delivering letters on which postage was pre-paid. ${ }^{226}$ Riders frequently overcharged recipients and pocketed the excess, ${ }^{227}$ and they took time to tend to their personal carrying business before attending to that of the post office. ${ }^{228}$ Some local postmasters who printed newspapers delayed mails containing other newspapers while they pirated items for their own publications. ${ }^{229}$

Finlay concluded that in the restless state of the colonies, attempts to enforce the law would have been useless. His report written in Salem, Massachusetts, is illustrative:

October 11th.- [Deputy Postmaster Edward Norice's] books were not in good order, he follows the form, but they are dirty and not brought up regularly; he understands the business of a deputy. The office is kept in a small mean looking place. He teaches writing. He has no commission

217 FINLAY, supra note 1, at 52-53.

218 Id. at 91-92. The mandates were imposed by 9 Ann., c. 10 (1711), § 19. A domestic American legislature - that of North Carolina-imposed the same mandates. 9 N.C. RECORDS, supra note 1, at 438-39 (Mar. 4, 1773), but allowed double fare to the ferryman.

219 FInLAY, supra note 1, at 30 (describing John Carter, deputy postmaster for Providence, Rhode Island, as a "seemingly active sensible man"); FARRAND, supra note 1, at 40 (stating of the New Haven, Connecticut, deputy postmaster, "he understands his business thoroughly"); FARRAND, supra note 1, at 57 (stating of the Savannah, Georgia deputy that "he is an excellent officer.").

220 E.g., FinlaY, supra note 1, at 33 (reporting that the Bristol, Connecticut deputy postmaster had no credentials) \& 89 (reporting that the postmaster at Suffolk, Virginia had no credentials).

221 Id. at 18 (describing private stage coach carriers, one of which was eventually hired by the official system).

222 FINLAY, supra note 1, at 32 (describing that of Peter Mumford in Newport, Rhode Island).

223 Id. at 28; 32, $35 \& 38$ (describing the practices of Peter Mumford). See also id. at 39, $40-41 \& 55$.

224 Id. at 40-41. See also id. at 43.

225 Id. at 39 ("Many people ask'd me if I had not met the Post driving some oxen"). See also id. at 41 .

$226 I d$. at 45 ("I find that it is the constant practice of all the riders between New York and Boston to defraud the Revenue as much as they can in pocketing the postage of all way letters").

227 Id. at $43-44,45 \& 67$.

228 Id. at $38 \& 42$.

$229 I d$. at 31 (reporting on this practice by the New London postmaster). 
[i.e., formal credentials] to act, he took charge of the office at the death of his father; he reports that every other day the stage coach goes for Boston, the drivers take many letters, so that but few are forwarded by Post to or from his office. If an information were lodged (but an informer wou'd get tar'd and feather'd) no jury wou'd find the fact; it is deemed necessary to hinder all acts of Parliament from taking effect in America. They are they say to be governed by laws of their own framing and no other. ${ }^{230}$

Distaste for the imperial post induced Americans to opt out. In 1774, William Goddard, ${ }^{231}$ a Baltimore printer, proposed a "constitutional post office" as a replacement. His quarrels with the imperial system were based partly on insecurity of the mail, but he also claimed that its fees represented unconstitutional taxation. ${ }^{232}$ Yet even Goddard based his proposed service closely on British rules and procedures. ${ }^{233}$

On April 28, 1775, Boston's committee of safety recommended establishment of new postal services, and the following month it created its own routes. ${ }^{234}$ In June 1775 , the Rhode Island legislature voted to establish a state post office, pending cooperation with other colonies to establish a continental system. The Rhode Island legislature elected Peter Mumford - one of the post boys Finlay had found so troublesome - as its rider from Newport to Providence, instructing him and his colleague (also a Mumford) to refuse to cooperate with the imperial post office. ${ }^{235}$

Goddard was unsuccessful in convincing the First Continental Congress to sponsor his "constitutional post office." $236 \mathrm{He}$ also was unsuccessful with the Second Continental Congress, apparently due in part to the opposition of Franklin, who wanted to operate the new institution himself. ${ }^{237}$ On May 29, 1775, Congress placed Franklin on a committee "to consider the best means of establishing posts for conveying letters and intelligence through this continent. ${ }^{238}$ When, on July 21, Franklin presented Congress with his proposed Articles of Confederation, they included provision for "the Establishment of Posts." ${ }^{239}$ Five days later Congress

230 Id. at 23-24 \& 40. See also id. at 32 ("Were any Deputy Post Master to do his duty, and make a stir in such matter, he would draw on himself the odium of his neighbours and be marked as the friend of Slavery and oppression and a declar'd enemy to America.").

231 On Goddard's career and activities, see JAFFe, supra note 1, at 53-55 \& 61-62 \& 63-65; Adelman, supra note 1, at 725-28, 732 \& 740.

232 Rich, supra note 1 , at 43.

233 Id. at 44; Adelman, supra note 1, at 728:

$[\mathrm{T}]$ he operational details of the post office that Goddard proposed differed little from those of the existing imperial system. The plan proposed no new routes, nor any new way to provide postal service to correspondents. As Thomas Young noted to John Lamb in May 1774, "We would not be under the least difficulty in this Colony" in making the transition from imperial to "constitutional" post," as there would be no change in the persons employed."

234 Rich, supra note 1 , at 46.

235 Resolution of Rhode Island Legislature, in 7 Records of THE Colony of Rhode IsLand and Providence Plantations 351-53 (1775) (Providence, A. Crawford Green, 1862).

236 J. Cont. Cong., supra note 1, at 55 (Oct. 5, 1774).

237 JAFFe, supra note 1, at 65.

2382 J. Cont. Cong., supra note 1, at 71 (May 29, 1775).

2392 J. Cont. Cong., supra note 1, at 195 (July 21, 1775). 
resolved to begin service, and selected Franklin as postmaster general. ${ }^{240}$ Franklin, in turn, named his son-in-law, Richard Bache, as controller and deputy and Goddard as surveyor (inspector). ${ }^{241}$

Congress authorized a line of posts from Falmouth to Savannah-the same route then served by the royal post. All profits were to be paid to the treasury. Presumably as an inducement for the public to utilize the congressional network, postage rates were slashed 20 percent. ${ }^{242}$ Shortly thereafter, Congress abandoned the price cut because the lower rates could not support the necessary riders. ${ }^{243}$

The royal post, shunned by the public, formally closed its doors on December 25, 1775. ${ }^{244}$ Finlay remained in Quebec. From at least 1784 he served as postmaster there; in 1787 he corresponded with U.S. postmaster Ebenezer Hazard, ${ }^{245}$ and in 1792 he negotiated a postal convention with the United States. ${ }^{246}$

\section{The Continental Post Office in the SunRise of INDEPENDENCE}

\section{A. The Vocabulary of the Continental Post OfFice}

Because the new United States post office was the direct successor to the North American branch of the imperial system-even many of the personnel and operational policies were the same ${ }^{247}$ - American postal vocabulary was identical to British vocabulary. A post office was the same thing in America as in Britain. A courier was a "post" 248 or "post boy." 249 The same meaning was assigned to the verb "establish," both as to the postal system in general, ${ }^{250}$ and as to specific elements

240 Id. at 209 (Jul. 26, 1775).

241 JAFE, supra note 1, at 65; RICH, supra note 1, at 48-49.

2422 J. Cont. Cong., supra note 1, at 203-09 (Jul. 26, 1775). When in England, Franklin had successfully lobbied for lower postage rates, accurately predicting that the result would be more business and more revenue. JAFFe, supra note 1, at 43 \& 62 .

2432 J. Cont. Cong., supra note 1, at 267 (Sept. 30, 1775).

244 Roper, supra note 1, at 40; Smith, supra note 1, at 275.

24532 J. Cont. Cong., supra note 1, at 79-80 (Feb. 26, 1787).

246 Steele, Finlay, supra note 1. Finlay died in Quebec in 1801, and subsequently became known as the "father of the Canadian post office." Id.

247 Adelman, supra note 1 , at $742 \& 744$.

2485 N.C. ReCORDS, supra note 1, at 732 (Oct. 23, 1756) (referring to a courier as a "post"); id. at 918 (Dec. 10, 1757) (same).

$2495 \mathrm{id}$. at 684 (Oct. 23, 1756) (reproducing a letter from the speaker of the lower house referring to a mail courier as a "post boy"); $i d$. at 732 (Oct. 23, 1756) (same); CLYDE Augustus Duniway, The Development of Freedom of the Press in Massachusetts 131 (1906) (reporting that the title of an eighteenth century Massachusetts paper was The Gazette and Post-Boy).

250 See infra Part III.A. See also Statutes of the State of Vermont Passed by the Legislature in February and March 1787 116-17 (1787) (reproducing "An act for establishing PostOffices within this State," which act provided for offices, post riding, postage, financial accounting, monopoly status, franking, and authorization for additional offices); Adelman, supra note 1, at 736 (quoting an 1774, an essay in the Connecticut Gazette referring to the post office as "a parliamentary Establishment"); 5 N.C. RECORDS, supra note 1, at 516 (Oct. 14,1755 ) (reproducing note from house speaker referring to "Established Post"); id. at 555 
of it. ${ }^{251}$ I have not found pre-constitutional references to "establishing post roads," but the term must have been similarly broad: In American usage, to "establish" a road included not just designating it (as Thomas Jefferson once suggested) ${ }^{252}$ but surveying and laying it out, cutting and improving it, and dedicating it. ${ }^{253}$

\section{B. The Purposes of the Continental Post Office}

During the time of the Continental Congress (1775-81) and the Confederation Congress (1781-89), the Post Office functioned as one of several executive departments reporting directly to Congress. ${ }^{254}$ In general, Congress saw the purposes

("establishing a post for one year from this to Neighbouring Colonies"); 6 id. at 484 (Nov. 18,1760 ) (referring to a "Bill for Establishing a post office"); id. at 853 (Nov. 22, 1762) ("A Bill for Establishing a Post thro this Province"); 7 id. at 413 (Nov. 28, 1766) (reporting resolution stating "that after the Post Master General shall have Established a post"); 8 id. at 365 (Jan. 17, 1771) ("A Bill to encourage and support the establishment of a Post Office in this Province"); 9 id. at 541 (Feb. 25, 1773) ("the establishment of a post office"); Letter from John Adams to James Warren (Jul. 26, 1775) in 2 Delegate LetTERs, supra note 1, at 667, 668 ("We shall establish a Post office").

Thus, the recorded assertion by the distinguished legal commentator John Norton Pomeroy that the verb establish "poorly express[es] the object" of creating and regulating the postal system, Rogers, supra note 1, at 24-25 (quoting Pomeroy), reflected Pomeroy's unfamiliarity with founding-era vocabulary.

251 E.g., Editor's note to Letter from Benjamin Franklin to Joseph Greenleaf (Oct. 26, 1775) in 2 Delegate Letters, supra note 1, at 255 (referring to a Massachusetts "committee 'for establishing post offices and post riders"'); Letter from Roger Sherman to Jonathan Trumbull, Sr. (Dec. 28, 1779) in 14 Delegate LetTERs, supra note 1, at 305 (mentioning an "establishment" of express riders); 23 J. ConT. Cong., supra note 1, at 673 (Oct. 18, 1782) (referring, in the governing ordinance of the postal system, to establishing a public rider on a cross-road); $i d$. at 676 (referring to establishment an individual post office).

252 Letter from Thomas Jefferson to James Madison (Mar. 5, 1796), in ThE Founders' Constitution (Philip B. Kurland \& Ralph Lerner eds. 1987), available at http://press-pubs. uchicago.edu/founders/documents/a1_8_7s4.html (last visited Feb. 28, 2018) ("Does the power to establish post roads, given you by Congress, mean that you shall make the roads, or only select from those already made, those on which there shall be a post? If the term be equivocal, [\& I really do not think it so,] which is the safest construction?") (italics in original); but see Letter from John Jay to George Washingon (Nov. 13, 1790), http:// founders.archives.gov/documents/Washington/05-06-02-0313 (arguing that the power to establish post roads includes authority to repair the roads) (last visited Feb. 28, 2018).

253 LAWS OF MARYLAND, 1765, c. xv (reproducing "an Act to establish a road," to include clearing, opening, repairing, and financing the road); $i d$. 1783, c. xi (reproducing a law to "lay out and establish a public road," including appointment of commissioners, authorizing them to lay out the road of a specified width, and providing for compensation to injured landowners); 7 The Public Records of the State of Connecticut 160 (Leonard Woods Labaree ed. 1948) (reproducing a public act in which the designation, laying out, and approval of a road are described as rendering it "fully established for a public Highway"); STATUTES of tHE STATE OF Vermont Passed by the Legislature in February and March 1787 at 79 (1787) (including in "establish" the steps taken by a court to open a road); $c f .5$ N.C. RECORDS, supra note 1, at 687 (Oct. 25, 1756) (recording presentation to the governor of "a Bill for establishing public roads and Ferries and for the better regulation of the same").

254 By the end of the Confederation era the congressional bureaucracy included, in addition to the post office, departments of war and foreign affairs (each administered by a 
of the post office in much the same way the British did: as a medium for official government intercourse, as a source of government intelligence and revenue, and as an aid for commerce. The system was, as Ben Franklin said of the newspapers it distributed, "useful to Government, and advantageous to Commerce, and to the Publick." ${ }^{255}$ In that order.

Congress's actual or perceived need for intelligence often motivated its postal decisions ${ }^{256}$ Congress created a British-style "dead letter office," with an inspector "to examine all dead letters at the expiration of each quarter; to communicate to Congress such letters as contain inimical schemes or intelligence." ${ }^{257}$ The 1782 postal ordinance, adopted after active hostilities had ceased, authorized army generals and state chief executives to open mail in wartime, and the president of Congress to do so at any time. ${ }^{258}$ Three years later, Congress empowered the Secretary of Foreign Affairs (John Jay) to open any letters if he deemed the country's "safety or interest require[d] it," but exempted letters franked by, or addressed to, members of Congress. ${ }^{259}$ The congressional resolution contained a sunset date, but the following year Congress extended Jay's power indefinitely. ${ }^{260}$

As in Britain, some official postal espionage took place without legal sanction. In 1788 Postmaster General Ebenezer Hazard informed Congress that the president of Pennsylvania had been opening private mail, or at least attempting to do so. Hazard questioned whether this was permitted, ${ }^{261}$ and Congress referred his question to a committee. The committee concluded as follows:

secretary), and a department of finance (administered by the board of treasury consisting of three commissioners). There were other officers as well, including superintendents of Indian affairs for the northern and southern departments.

Confederation executive and judicial functions have, perhaps, been too little studied, since Confederation-era usage has consequences for constitutional interpretation-for example, in defining the meaning of the constitutional word "department." E.g., U.S. Const. art. I, $\S 8$, cl. 18 ("To make all Laws which shall be necessary and proper for carrying into Execution the foregoing Powers, and all other Powers vested. . . in any Department . . . thereof."); id. art. II, § 2, cl. 1 ("The President . . . may require the Opinion, in writing, of the principal Officer in each of the executive Departments").

255 Quoted in JAFFE, supra note 1, at 42.

256 E.g., 5 J. Cont. Cong., supra note 1, at 717-18 (Aug. 20, 1776) (appointing committee to consider establishing "advice boats" "so as to facilitate and expedite the conveying of intelligence"); $i d$. at 720 (Aug. 30, 1776) ("That the communication of intelligence with frequency and despatch [sic], from one Part to another of this extensive continent, is essentially requisite to its safety"); $6 \mathrm{id}$. at 927 (Nov. 5, 1776) (instructing the postmaster general to hire more riders "for obtaining early and frequent intelligence" from the armies); $17 \mathrm{id}$. at 467 (May 27, 1780 ("the establishment of Posts and expresses who shall bring the earliest intelligence of the arrival of the fleet of our ally and the motions of the Enemy").

See also Letter from Benjamin Franklin to Ebenezer Hazard (Sept. 25, 1775) in 2 Delegate LetTers, supra note 1, at 56 (stating, "It seems the more necessary to establish Speedily a Post to Albany, as we have an Army on your Frontiers.").

Thus, Professor Desai's description of the post office at this time as "simply a revenuegenerating enterprise," Desai, supra note 1, at 677, was much too limited.

2579 J. Cont. Cong., supra note 1, at 817 (Oct. 17, 1777).

25823 id. at 671 (Oct. 18, 1782).

$25929 \mathrm{id}$. at 685 (Sept. 7, 1785).

$26031 \mathrm{id}$. at 909 (Oct. 23, 1786).

$26134 \mathrm{id}$. at 232 (Jun. 13, 1788) (reproducing letter). 
- Because of Congress's exclusive power over the post office, only Congress could delegate authority to open private letters.

- Congress had delegated such authority to state chief executives for the duration of the Revolutionary War, ${ }^{262}$ but it had expired when the war ended.

- It would improper to delegate such authority to any person not "immediately under the controul of and responsible to Congress." 263

The Pennsylvania president on the receiving end of this slapdown was Ben Franklin.

Congress hoped to use the post office as a source of general revenue as well as of intelligence. ${ }^{264}$ Congress considered revenue effects when it fixed rates ${ }^{265}$ and when it weighed whether and where to add new routes. ${ }^{266}$

During the war years generating income was difficult. Congress repeatedly raised rates and salaries to offset wartime inflation. ${ }^{267}$ It also experimented with lowering rates to increase demand. ${ }^{268}$ On occasion it tried to cut expenses, but its efforts were not consistent. In 1779, for example, Congress fired all express riders ${ }^{269}$ - but in the same resolution raised salaries and allowances. ${ }^{270}$ By late 1781, express riders were for some reason once again in post office employ, and again Congress voted to terminate them. ${ }^{271}$

During the war Congress frequently had to cover deficits. ${ }^{272}$ Not until hostilities

$23 \mathrm{id}$. at 671 (Oct. 18, 1782) (reproducing the congressional ordinance).

34 id. at 239 (Jun. 18, 1788).

264 E.g., 12 id. at 930 (Sept. 19, 1778) (committee report on application of postal revenue).

$26531 \mathrm{id}$. at 116 (Feb. 26, 1786) (producing letter by postmaster general on the subject); 33 $i d$. at 695 (Oct. 20, 1787) (reproducing congressional resolution reducing rates on large packages to increase revenue).

266 E.g., 32 id. at 59 (Feb. 15, 1787) (reproducing letter of postmaster Ebenezer Hazard stating that a particular route would have the advantage of "greatly encreasing the Revenues of the General Post Office"). See also id. at 60 (reproducing congressional resolution conditioning contract on not "occasion[ing] an expence to the general post); $34 \mathrm{id}$. at 76 (Mar. 3, 1788) (reproducing a letter from the postmaster general assessing the financial aspects of a Philadelphia-to-Pittsburgh route).

267 E.g., 9 id. at 817 (Oct. 17, 1777) (rate increase of 50 percent); 13 id. at 463 (Apr. 16, 1779) (rate doubling); 16 id. at 413 (May 5, 1780) (rate doubling); $19 \mathrm{id}$. at 191 (Feb. 24, 1781) (rate doubling). See also $18 \mathrm{id}$. at 1142 (Dec. 12, 1780) (salary increases)

$26821 \mathrm{id}$. at 1066 (Oct. 19, 1781).

269 Letter from Roger Sherman to Jonathan Trumbull, Sr. (Dec. 28, 1779) in 14 Delegate LETTERS, supra note 1, at 305 (mentioning a congressional resolution discharging express riders, "which establishment had envolved [sic] the public in a very enormous expense").

27015 J. Cont. Cong., supra note 1, at 1419 (Dec. 27, 1779) (cutting express riders while increasing the salary of the post master general and allowances to surveyors).

27121 J. Cont. Cong., supra note 1, at 1067 (Oct. 19, 1781).

272 E.g., 13 id. at 74 (Jan. 16, 1779) (payment to the postmaster general of \$20,000); $13 \mathrm{id}$. at 463 (Apr. 16, 1779) (payment of additional amounts of $\$ 6967$ and $\$ 5000) ; 14 i d$. at 633 (May 22, 1779) (payment of \$10,000). See also 15 id. at1203-04 (Oct. 23, 1779) (reporting large deficits). 
were over and Ebenezer Hazard had replaced Richard Bache as postmaster did the department run a profit. ${ }^{273}$

The importance of the post office as an aid to commerce was reinforced by the close relationship between trade and revenue. As Postmaster General Hazard repeatedly reminded Congress, merchants were by far the system's most important paying customers. ${ }^{274}$

\section{Congress Decides to EMUlate the BRItish}

In most respects the structure of the American post office, as well as its goals, mirrored that of the British. Congress required operatives to take loyalty oaths, as in Britain. ${ }^{275}$ The administrative structure - postmaster general, surveyor, and local deputies - was similar. The system enjoyed British-style legal privileges. Among these were carriage mandates on ferries ${ }^{276}$ and a near-monopoly on carrying letters and packages. Efforts to breach the monopoly were taken very seriously. ${ }^{277}$ There were also privileges for postal workers. In 1776, Congress recommended to the states that they excuse deputy post masters from any public duties "which may call them from attendance at their offices," 278 and Congress directly exempted riders from military obligations. ${ }^{279}$ The following year, Congress extended the exemption from military conscription to everyone working for the postal service. ${ }^{280}$

Congress granted franking privileges much as Parliament did. "[T]he members of Congress were determined to enjoy all the privileges of officials under the old [royal] office, for on November 8 [1775] it was provided that all letters and packets sent or addressed to the delegates should be free during the sessions of Congress." 281

Insofar as American practices were looser than those in Britain, officials made efforts to tighten them. While still post office surveyor, Ebenezer Hazard wrote to the North Carolina legislature asking that it impose British-style mandates on ship

28 id. at 109 (Feb. 28, 1785); Letter from George Washington to Ebenezer Hazard (Jul. 3, 1789), http://founders.archives.gov/documents/Washington/05-03-02-0049 (observing that the post office had been generally profitable since 1782, the year Hazard became postmaster general).

$27429 \mathrm{id}$. at 527 (Jul. 12, 1785) (reproducing a letter from the postmaster general in which he refers to "the mercantile Interest, from whence the Post Office Establishment derives its principal Support"); 33 id. at 671, 672 (Oct. 12, 1787) (reproducing letter from postmaster general stating, "Trade is the principal, and almost only, Support of the Post Office Department").

$27510 \mathrm{id}$. at 69 (Jan. 21, 1778).

2766 id. at 927 (Nov. 5, 1776).

2776 id. at 927 (Nov. 5, 1776) (denying payment to post riders who take letters and packages on their own account); $12 \mathrm{id}$. at 463 (Apr. 16, 1779) (plea to public to use the post office and not to send letters "through any oeconomical view, by a private conveyance"); 27 $i d$. at 582-83 (July 10, 1784); (prosecution of person carrying letters); 27 id. at 584 (Jul. $10,1784)$ (describing action to suppress independent packet boats delivering mail); $i d$. at 585 (Jul.12, 1784) (same).

2785 id. at 720 (Aug. 30, 1776).

$2795 \mathrm{id}$. at 638 (Aug. 8, 1776).

$2807 \mathrm{id}$. at 347 (May 12, 1777).

281 Rich, supra note 1, at 50. 
masters and increase its mandates on ferries. ${ }^{282}$ As postmaster general, he urged Congress to stiffen the rules on carriages traveling the post roads and on ships carrying mail from overseas. ${ }^{283}$ His recommendations were included in Congress's proposed ordinance of $1787 .{ }^{284}$

\section{Regularizing Postal LaW Under the Articles of Confederation}

In 1777, Congress adopted the final version of the Articles of Confederation ${ }^{285}$ and began to operate under them de facto, although they were not fully ratified until March, $1781 .{ }^{286}$ Article IX provided in part:

The United States in Congress assembled shall also have the sole and exclusive right and power of . . establishing or regulating post offices from one State to another, throughout all the United States, and exacting such postage on the papers passing through the same as may be requisite to defray the expenses of the said office ... ${ }^{287}$

During the 1780s, Congress negotiated a postal convention with France ${ }^{288}$ and sought to expand the practice of paying postage in advance rather than upon receipt. ${ }^{289}$ More important for constitutional interpretation were efforts at comprehensive statutory reform - then referred to as the "new establishment." ${ }^{290}$ In August, 1781, Congress authorized an expanded post office committee to "prepare and report the state of the present expences of the Post Office, and a system for regulating the same in future." ${ }^{291}$ The target date was for December 1, 1781, ${ }^{292}$ but Congress subsequently postponed it to January $1,1782^{293}$ and later to February $1 .^{294}$ The committee finally produced a draft ordinance in March. ${ }^{295}$ Nothing further was reported until July $19,1782,{ }^{296}$ when a committee produced another draft. Congress adopted the final measure on October 18. It was entitled "An Ordinance for Regulating the

\footnotetext{
282 Memorial from Ebenezer Hazard to the North Carolina General Assembly (Apr. 6, 1778), in 12 N.C. RECORDS, supra note 1, at 395-96.

$28329 \mathrm{id}$. at 528 (Jul. 12, 1785) (reproducing letter of July 11).

$28432 \mathrm{id}$. at 51-52 (Feb. 14, 1787). For further discussion of the proposed ordinance, see infra Part III.D.

2859 id. at 907 (Nov. 15, 1777)

$28619 \mathrm{id}$. at 214 (Mar. 1, 1781) (recording final ratification).

287 ARTs. CONFED., art. IX.

28830 J. Cont. Cong., supra note 1, at 80-82 (Feb. 15, 1786) (reproducing some of the proceedings); $30 \mathrm{id}$. at 141-42 (Mar. 29, 1786) (same).

$28931 \mathrm{id}$. at 674 (Sept. 20, 1786).

$29016 \mathrm{id}$. at $413 \& 414$ (May 5, 1780) (recording two uses of the phrase).

$29112 \mathrm{id}$. at 820 (Aug. 1, 1781).

$29221 \mathrm{id}$. at 1067 (Oct. 19, 1781) (providing that the coming "establishment of the Post Office" occur on December 1).

$29321 \mathrm{id}$. at 1131 (Nov. 22, 1781).

$29422 \mathrm{id}$. at 1 (Jan. 2, 1782) ("Resolved, That the post office be continued on the old establishment until the first day of February next").

$29522 \mathrm{id}$. at 121-26 (Mar. 11, 1782) (reproducing draft ordinance).

$29622 \mathrm{id}$. at 402 (Jul. 19, 1782).
} 
Post Office of the United States of America." ${ }^{297}$ On October 28 Congress added a "supplemental ordinance," 298 and on December 24 "An Ordinance for Amending An Ordinance Regulating the Post Office of the United States of America."299

In the main, the 1782 measures tracked the subject matter of Parliament's 1711 statute and of subsequent parliamentary enactments. ${ }^{300}$ The new ordinances authorized a network extending from New Hampshire to Georgia, empowered the postmaster general to hire personnel at stated rates of compensation, and authorized him to supervise the entire system. The ordinances fixed postage rates (by page for most letters and by weight for larger items, with no weight limit), delineated rules for ships carrying in mail from overseas, defined postal offenses and punishments, designated courts for prosecution of offenses, prescribed an oath for post office personnel, and issued rules by which officials could open letters. The ordinances imposed, with certain exceptions, a letter-carrying monopoly. ${ }^{301}$ They contained provisions for dead letters ${ }^{302}$ and franking exemptions. ${ }^{303}$ The growing popularity of newspapers was acknowledged by allowing post riders to carry them "at such moderate rates as the Postmaster General shall establish." ${ }^{304}$

In a few respects the ordinances departed from British precedents. They did not disqualify postal personnel from parliamentary politics because America had no general parliament. They did not attempt to control transportation on the post roads; any such regulation would have been impossible to enforce. The principal ordinance seemed to subordinate revenue-raising to conveyance of information: It recited "the communication of intelligence with regularity and despatch" 305 as a primary justification for the post office and provided that after the debt to Congress was re-paid, any surplus would be reinvested in the post office. ${ }^{306}$ This language notwithstanding, revenue remained a significant concern. ${ }^{307}$

Congress eventually concluded that the 1782 reforms were not sufficient. On February 25, 1786, it appointed a new committee "to prepare and report an Ordinance on the post Office." ${ }^{\prime 308}$ The committee produced a draft on February 14, 1787, entitled "An Ordinance for Regulating the Post Office of the United States

\footnotetext{
23 id. at $670-78$ (Oct. 18, 1782).

23 id. at 688-89 (Oct. 28, 1782).

$29923 \mathrm{id}$. at 880 (Dec. 24, 1782). An earlier version had been defeated. Id. at 754-55 (Nov. 27, 1782), 757 (Dec. 2, 1782), 764 (Dec. 4, 1782) \& 770 (Dec. 6, 1782).

300 Supra Parts I.E \& I.F.

301 See generally An Ordinance for Regulating the Post Office of the United States of America, 23 J. Cont. Cong., supra note 1, at 670-78 (Oct. 18, 1782) (setting forth these provisions).

302 Id. at 675 (Oct. 18, 1782); id. at 689 (Oct. 28, 1782).

30323 J. Cont. Cong., supra note 1, at 830 (Dec. 24, 1782).

30423 id. at677 (Oct. 18, 1782).

$30523 \mathrm{id}$. at 670 (Oct. 18, 1782).

306 Id. at 677 (Oct. 18, 1782).

307 E.g., 34 J. Cont. Cong., supra note 1, at 76 (Mar. 3, 1788) (reproducing a letter from the postmaster general assessing the financial aspects of a Philadelphia-to-Pittsburgh route); see also John, SpREAding, supra note 1, at 26 ("Long after the break with Great Britain, this rationale [revenue] remained influential in the United States, with public figures taking it more or less for granted that postage ... should be treated as a tax.").

30830 J. Cont. Cong., supra note 1, at 84 (Feb. 25, 1986).
} 
of America." ${ }^{309}$ This ordinance essentially re-codified and reinforced existing practice. It would have added two assistant postmasters general, and required them to visit every office in their respective districts at least every six months. It would have fixed rates for conveyance of periodicals, and required that they be dry when deposited into postal custody. It sought to formalize the custom ${ }^{310}$ of permitting newspaper owners to exchange papers with each other without charge and allowed printers to send newspapers to subscribers at fixed fees.

When the Constitutional Convention met, this draft ordinance represented the latest official thinking on postal affairs. The following year the Confederation Congress adopted the newspaper exchange provision, ${ }^{311}$ and in 1792 the Federal Congress enacted the fixed fee for newspaper postage. ${ }^{312}$

\section{E. The Woes of a STATE-OWNED ENTERPRISE}

\section{Problems Inherited from the British Model}

Having copied the British model, Congress had to wrestle with its inherent defects. As in Britain, post riders were a persistent problem. They were often tardy, and they undertook for their own profit tasks that interfered with their postal duties. ${ }^{313}$ On some routes, coaches were a possible alternative to riders. But coaches could be prohibitively expensive, and their owners insisted on schedules inconvenient for the merchants who were the post office's most important customers. ${ }^{314}$

Another weakness in the British model was its vulnerability to political meddling. Mail-tampering was widely suspected ${ }^{315}$ Franking made it harder for the system to earn a profit, and franking seemed constantly to increase. Members of Congress, of course, held the frank. Congress extended it to the lower ranks in the Continental Army, ${ }^{316}$ then to army officers, ${ }^{317}$ army generals, ${ }^{318}$ diplomatic officers, ${ }^{319}$ the director of the hospital, ${ }^{320}$ delegates to the Constitutional Convention, ${ }^{321}$ and

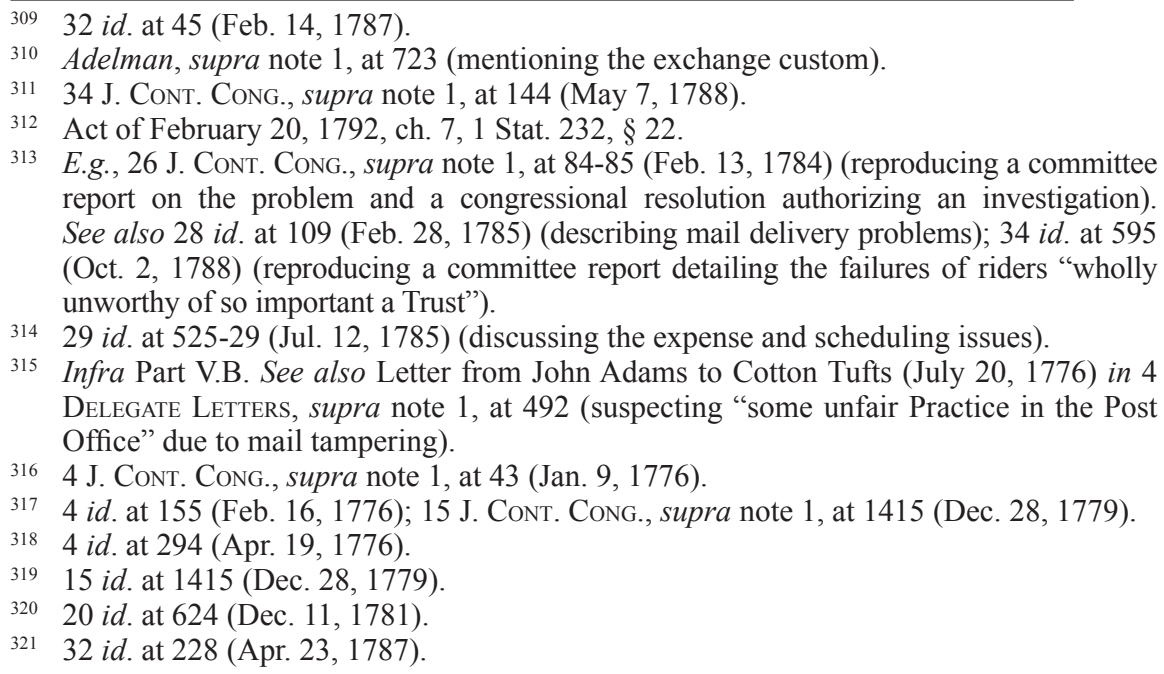

315 Infra Part V.B. See also Letter from John Adams to Cotton Tufts (July 20, 1776) in 4 Delegate Letters, supra note 1, at 492 (suspecting "some unfair Practice in the Post Office" due to mail tampering).

3164 J. Cont. Cong., supra note 1, at 43 (Jan. 9, 1776).

3174 id. at 155 (Feb. 16, 1776); 15 J. Cont. Cong., supra note 1, at 1415 (Dec. 28, 1779).

$3184 i d$. at 294 (Apr. 19, 1776).

$31915 \mathrm{id}$. at 1415 (Dec. 28, 1779).

$32020 \mathrm{id}$. at 624 (Dec. 11, 1781).

$32132 \mathrm{id}$. at 228 (Apr. 23, 1787). 
General George Washington after he had left active duty. ${ }^{322}$ A motion in Congress on August 2, 1781 to end the practice ${ }^{323}$ was defeated. ${ }^{324} \mathrm{~A}$ few days later, a special committee also recommended that franking cease. ${ }^{325}$ Instead, Congress extended the privilege, ${ }^{326}$ as when it permitted department heads to frank even if they neglected to write an "on public service" legend on the outside of the letter. ${ }^{327}$ By 1790, abuse was very widespread: ${ }^{328}$ According to one estimate, franking and unauthorized private delivery were costing the post office seven-eighths of its potential revenue. ${ }^{329}$

Demands for patronage represented another kind of political meddling. Benjamin Franklin was the master demander. Under British rule he had filled post office jobs with family and business associates, ${ }^{330}$ and in 1776 , he convinced Congress to allow his son-in-law, Richard Bache, to replace him as postmaster general. ${ }^{331}$ Bache proved less able than necessary to operate the post office under trying wartime conditions. ${ }^{332}$ Congress responded by repeatedly raising his salary. ${ }^{333}$

Bache finally retired in 1782, after which Congress learned that he had allowed the post office to run out of such basic supplies as account books and portmantles, and had considerably overpaid the post riders. ${ }^{334}$

The choice of Bache's successor was more fortunate. Ebenezer Hazard ${ }^{335}$ was well qualified for the job. He had served as "constitutional postmaster" in New

$32226 \mathrm{id}$. at 314 (Apr. 28, 1784). Washington hardly needed the privilege. At the time he may have been the wealthiest man in America.

$32321 \mathrm{id}$. at 828 (Aug. 2, 1781).

$32421 \mathrm{id}$. at 1054 (Oct. 15, 1781).

$32521 \mathrm{id}$. at 1066 (Oct. 19, 1781).

$32623 \mathrm{id}$. at 678 (Oct. 18, 1782); 23 id. at 880 (Dec. 23, 1782).

$32724 \mathrm{id}$. at 156-57 (Feb. 28, 1783). This was before envelopes came into common use. Letters were folded and addresses written on the outside. See also Letter from Elbridge Gerry to Abigail Adams (Nov. 1, 1783) in 21 Delegate Letters, supra note 1, at 148 (complaining of postmasters' refusal to honor the frank, apparently subsequent to the congressional resolution, when an "on publick Business" legend was omitted in order to save the post office money).

32815 First CONGRESS, supra note 1, at xx-xxii (2004) (editor's note on franking and its abuses).

3291 AnNALs of Cong. 1567 (reproducing remarks by Jeremiah Wadsworth) (April 1, 1790). Postmaster General Samuel Osgood, however, stated that the amount lost from franking was impossible to quantify. Postmaster General's Report, Jan. 20, 1790, in 1 AnNALs of Cong. 2161, 2161.

330 Adelman, supra note 1 , at 717.

331 LeECH, supra note 1, at 9. 6 J. Cont. Cong., supra note 1, at 931 (Nov. 7, 1776).

332 Letter from John Hancock, president of Congress, to Richard Bache (Jan. 13, 1777) in 6 Delegate LetTERs, supra note 1, at 90 (complaining of late delivery, disloyal riders, and lack of compliance with congressional directions); Letter from John Adams to Thomas Jefferson (May 26, 1777) in 7 Delegate Letters, supra note 1, at 120 (reporting that a congressional "Committee on the Post office, too, have found, a thousand difficulties," and looking to surveyor Ebenezer Hazard to set things right); 6 JoHn, Spreading, supra note 1, at 27 (accusing Bache of "incompetence"). I have adopted a more guarded assessment than Professor John because of the enormous wartime challenges under which Bache worked.

333 E.g., 13 J. Cont. Cong., supra note 1, at 464 (Apr. 16, 1779); 15 id. at 1339 (Dec. 1, 1779); $15 \mathrm{id}$. at 1419 (Dec. 27, 1779); $16 \mathrm{id}$. at 19 (Jan. 6, 1780).

$33423 \mathrm{id}$. at 548 (Sept. 5, 1782).

335 Letter from John Hanson as president of Congress to Ebenezer Hazard (Jan. 30, 1782) in 18 Delegate Letters, supra note 1, at 315 (informing Hazard that "you are elected Post Master General"). 
York, ${ }^{336}$ and later as surveyor for the U.S. system. ${ }^{337}$ His work had received good reviews. ${ }^{338}$ By all accounts Hazard did a far better job as postmaster general than his predecessor. ${ }^{339}$ It is, perhaps, symbolic of the defects in the Anglo-American postal model that while Bache received multiple salary increases and continued in his position until he voluntarily retired, Hazard was to be skewered on the spit of political controversy. ${ }^{340}$

\section{Other Problems}

In Britain, Parliament left post office administration largely to the postmasters general. In this respect, Americans did not follow the British model. Congress never delegated much power to the administrators charged with running the post office.

Legally, this was justifiable. In Britain, parliamentary legislation delegated to officials the power to (in the words of one statute) "establish Post Offices and Post Roads." ${ }^{341}$ However, the Articles of Confederation granted Congress the "sole and exclusive right and power of . . . establishing or regulating post offices." ${ }^{342}$ This language seemingly required that Congress adopt a more hands-on approach than did the British Parliament.

Congress created a standing committee on the post office. ${ }^{343}$ Congress sometimes appointed ad hoc committees for special postal projects. ${ }^{344}$ The congressional journals show that these committees, and Congress itself, were

336 LeECH, supra note 1, at 9; Letter from Benjamin Franklin to Ebenezer Hazard (Aug. 3,1775 ), in 25 Delegate Letters, supra note 1, at 559 (stating that Hazard would be appointed).

337 JAFFe, supra note 1, at 84.

338 Letter from John Adams to Thomas Jefferson (May 26, 1777) in 7 Delegate Letters, supra note 1, at 120 (reporting on problems under Bache, and stating, "Mr. Hazard is now gone Southward, in the Character of Surveyor of the Post office, and I hope will have as good Success, as he lately had eastward, where he has put the office into good order").

33924 J. Cont. Cong., supra note 1, at 329 (May 5, 1783) (reproducing a laudatory committee report); $34 \mathrm{id}$. at 462, 463 (Aug. 27, 1788) (reproducing a committee report praising certain post office procedures); Letter from Charles Thomson as secretary of Congress to Ebenezer Hazard (Jun. 22, 1786) in 23 Delegate LetTers, supra note 1, at 369 (recording congressional approval of Hazard's decision not to accept paper money for postage).

340 Infra Part VII.C.

3417 Geo. 3, c. 50 (1767), $\$ 5$ (granting authority to "establish Post Offices and Post Roads" on the Isle of Man to the postmaster general); 5 Geo. i, c. $21 \S 11$ (granting authority to postmaster general and his deputies to establish "penny post" offices).

342 ARTs. CONFED., art. IX (1781).

343 E.g., 12 J. Cont. Cong., supra note 1, at 26 (Jan. 5, 1779) (referring to it as "the committee for superintending and regulating the post office"). Other references are too numerous to list. But see, e.g., 13 id. at 74 (Jan. 16, 1779) ("committee appointed to regulate the affairs of the post office"); $14 \mathrm{id}$. at 819 (Jul. 12, 1779) ("committee on the post office"); $15 \mathrm{id}$. at 1149 (Oct. 7, 1779) ("committee on the post office"); 16 id. at 12 (Jan. 3, 1780) ("committee on the Post-office").

344 E.g., 11 J. Cont. Cong., supra note 1, at 550 (May 29, 1778) ("Resolved, That a committee of four be appointed to report a plan for regulating continental expresses, and to enquire into and rectify abuses in the general post office"); $24 \mathrm{id}$. at 37 (Jan. 6, 1783) (appointment of a committee "to enquire fully into the proceedings of the Post Office"). 
deeply involved in postal administration. Sometimes the issues were relatively important, such as designation of routes, ${ }^{345}$ packet boat schedules, ${ }^{346}$ and whether coaches or riders were appropriate for particular routes. ${ }^{347}$ On other occasions, the issues were of the kind Congress easily could have delegated to the postal staff.

By way of illustration: Congress spent an untoward amount of time investigating incidents of mail robbery. ${ }^{348}$ Congress deemed it necessary to pass a resolution directing the postmaster general to fire a deputy and apprehend him for examination. ${ }^{349}$ Congress passed a resolution reinstating an express rider. ${ }^{350}$ Congressional expenditure authorizations extended to routine payments, reimbursements, and advances. ${ }^{351}$ At one point, Postmaster General Hazard felt compelled to write a lengthy letter to Congress explaining in detail how a delegate's mail been torn. ${ }^{352}$ And a congressional resolution was deemed necessary to pay a rider the sum of six dollars. ${ }^{353}$

Whatever might be the legal justification for Congress retaining so much control, the records demonstrate that a roomful of politicians is not a viable board of directors for a business enterprise. Congressional directions to the postmaster general sometimes were unclear or unwittingly contradicted earlier decisions. ${ }^{354}$ Congress often had trouble making up its collective mind. It doubled the pay of post riders, then suspended the increase three weeks later. ${ }^{355}$ It raised surveyors' fixed

345 E.g., 15 id. at 1411 (Dec. 27, 1779); 16 id. at 413 (May 5, 1780); 34 id. at 65 (Feb. 27, 1788).

346 E.g., 16 id. at 117 (Feb. 1, 1780).

347 E.g., 30 id. at 411 (Jan. 17, 1786 (reproducing motion of William Grayson for stage carriage); $31 \mathrm{id}$. at 501 (reproducing committee report for stage carriage and for leaving the mode of transportation for other routes to the postmaster general's discretion); 31 $i d$. at 630 (Sept. 4, 1786) ("the Post Master General be, and hereby is authorised and instructed to enter into contracts ... for the conveyance of the mails by stage carriages, if practicable, for one year") (emphasis added).

$34822 \mathrm{id}$. at 402 (Jul. 17, 1782); 25 id. at 790 (Nov. 1, 1783); 26 id. at 8-10 (Jan. 6, 1784) \& 26 id. at 201 (Apr. 6, 1784).

3496 id. at 968 (Nov. 20, 1776).

35016 id. at 283 (Mar. 23, 1780).

351 E.g., 6 id. at 978 (Nov. 23, 1776); 8 id. at 618 (Aug. 6, 1777).

352 The complaint is recorded in Letter from Benjamin Contee to Congress (Mar. 17, 1788) in 25 Delegate Letters, supra note 1, at 17 and Hazard's response in 34 J. Cont. Cong., supra note 1, at 144 (May 6, 1788). Hazard's response correspondence describes how the post office bundled and unbundled letters.

35326 J. Cont. Cong., supra note 1, at 201 (Apr. 6, 1784).

35434 J. Cont. Cong., supra note 1, at 312-15 (Jul. 9, 1788) (reproducing letter). Hazard's concluding paragraph was a pointed piece of diplomacy:

Your Excellency, I flatter myself, will excuse these Remarks, as the

Difficulties stated are obviously of such a Nature as to be insurmountable, except through the Intervention of Congress; and will your Excellency permit me to submit it to Consideration, whether a standing Instruction to Committees upon the Business of any Department, to consult with the Head of the Department upon the Object of their Appointment, would not be useful, as tending to furnish necessary Information, and to prevent Confusion.

$34 \mathrm{id}$. at 314-15 (italics added).

$35518 \mathrm{id}$. at 1142 (Dec. 12, 1780) (doubling pay); $19 \mathrm{id}$. at 22 (Jan. 4, 1781) (suspending increase). 
expense allowances, then repealed the increase and replaced it with reimbursement for documented expenses, and then repealed the reimbursement provision-all within the space of five months. ${ }^{356}$ Debates over postal routes were not so much discussions of public need as contests in raw political power, with each delegate struggling to obtain more subsidized service for his own constituents. ${ }^{357}$

This kind of administration necessarily reduced the ability of the system to respond to emergencies. Thus, when Congress proved unable to meet the needs of Virginia state government for wartime intelligence, Governor Thomas Jefferson took it upon himself to institute a line of expresses. ${ }^{358}$

\section{The Drafting of the Postal Clause}

\section{A. Why Adopt a Postal Clause?}

State owned enterprises suffer from widely-recognized challenges, particularly when they operate in non-competitive environments. These challenges include, but are not limited to, conflicting objectives, political interference, anti-competitive behavior, inefficient operations, and lack of accountability. ${ }^{359}$ With respect to postal services in particular, the pre-constitutional history of the British and American systems offer many specific illustrations of such difficulties. ${ }^{360}$

In other respects, the Constitution favored private and competitive solutions rather than government enterprises and monopoly. It did not establish a state church, for example, and it proscribed religious tests. ${ }^{361}$ It failed to list an explicit incorporation power because some framers feared such a power might spawn

35615 id. at 1412 (Dec. 27, 1779 (raising \$20 per day allowance to \$40); 16 id. at 21 (Jan. 7,1780 ) (repealing $\$ 40$ allowance and opting for reimbursement), $16 \mathrm{id}$. at 413 (May 5, 1780) (repealing reimbursement provision).

357 E.g., 34 J. Cont. Cong., supra note 1, at 161-63 (May 20, 1788); id. at 174 (May 22, 1788) (detailing rival proposed routes for Pennsylvania, Massachusetts, and Delaware). See also Letter from Nathaniel Peabody to Richard Bache (Aug. 30, 1780) in 15 Delegate LetTers, supra note 1, at 637 (containing demand from congressional delegate from New Hampshire for more postal service in his state).

358 Letter of Thomas Jefferson to the President of Congress (Samuel Huntington) (Jun. 9, 1780) in 3 The Works of Thomas JefFerson 15, 18-19 (Paul Leicester Ford ed., 1904) (reporting the problem); Letter of Thomas Jefferson to George Washington (Jun. 11, 1780), in id. at 19 (reporting the solution); Letter of Thomas Jefferson to the President of Congress (Samuel Huntington) (Jun. 15, 1780), in id. at 24 (reporting the solution); $17 \mathrm{~J}$. Cont. Cong., supra note 1, at $574 \& 575$ (June 29, 1780).

359 World Bank Group, Corporate Governance of State-Owned Enterprises: A Toolkit 1215 (2014), available at https://openknowledge.worldbank.org/bitstream/handle/1098 6/20390/9781464802225.pdf?sequence=1\&isAllowed=y. See also O E C D , OECD Guidelines on Corporate Governance of State-Owned Enterprises 12 (2015), available at http://www.oecd-ilibrary.org/governance/oecd-guidelines-on-corporategovernance-of-state-owned-enterprises-2015_9789264244160-en.

360 Supra Parts I.F \& III.E.

361 U.S. Const., art. VI, cl. 3 ("no religious Test shall ever be required as a Qualification to any Office or public Trust under the United States."). 
monopolies. ${ }^{362}$ Other than the post office, the Constitution did not authorize the federal government to erect state owned enterprises, such as the British government's lotteries or the Spanish government's monopoly of salt mines. ${ }^{363}$

Yet for postal services, the framers wrote into the Constitution a clause authorizing a state-owned monopoly, and this decision was almost unquestioned during the ratification debates. ${ }^{364}$

One underlying reason may have been that the founders were temperamentally disposed toward preservation. They fought a revolution, but a conservative revolution. They repudiated specific English institutions, but they did not repudiate their entire heritage. The Postal Clause is only one of many constitutional provisions reflecting continuity with England.

Moreover, Congress inherited the American branch of the imperial post office at a time when Congress desperately needed two benefits that institution traditionally provided: intelligence and revenue. The framers and ratifiers may have believed that a socialized monopoly was the only way the system could generate revenue. Some contemporaneous writers defended government postal monopolies on grounds similar to the modern economic concept of the "natural monopoly." 365 Adam Smith's Wealth of Nations - then an increasingly influential work ${ }^{366}$ strongly recommended that governments avoid other "mercantile projects," but was more favorable to government ownership of the post office: "It is perhaps the only mercantile project which has been successfully managed by, I believe, every sort of government. The capital to be advanced is not very considerable. There is no mystery in the business. The returns are not only certain, but immediate." ${ }^{\prime 367}$

Newspaper publishers saw the post office as a ready, and perhaps subsidized, way to deliver their product. A few outside the newspaper business envisioned the

3622 FARRAND, supra note 1, at 615-16 (Sept. 14, 1787) (Madison). Another reason was that some framers - not all - thought the power to regulate commerce already included a power to grant monopolies. Id. at 616. Cf. ROGERS, supra note 1, at 24 (attributing defeat of the canal power in part to antipathy to monopolies).

36327 Geo. 3, c. 41 (1788) (authorizing raising of money by lottery); JAIME VicENS Vives, An Economic History of Spain 529 (1969) (mentioning the Spanish government's salt monopoly); see also Smith, WeAlth supra note 1, at 468-71 (discussing other contemporaneous state owned enterprises).

364 Infra Part VII.B.

365 Natural Monopoly, Investopedia, http://www.investopedia.com/terms/n/natural monopoly.asp ("A natural monopoly is a type of monopoly that exists as a result of the high fixed costs or startup costs of operating a business in a specific industry."). $C f$. 1 William Blackstone, Commentaries at *312 ("[N]othing but an exclusive right can support an office of this sort: many rival independent offices would only serve to ruin one another."); ENCYClOPAEDIA BRITANNICA, supra note 1, at 6442 (repeating the same justification).

366 Samuel Fleischacker, Adam Smith's Reception Among the American Founders, 1776 1790, 59 Wm. \& Mary Q. 897, 901-04 (2002) (discussing evidence that the Founders read and admired The Wealth of Nations).

367 Smith, Wealth supra note 1, at 469. Of other state owned enterprises, he wrote: Princes, however, have frequently engaged in many other mercantile projects, and have been willing, like private persons, to mend their fortunes by becoming adventurers in the common branches of trade. They have scarce ever succeeded.

Id. 
post office as what it later became - a great democratic circulatory system. Dr. Benjamin Rush, a signer of the Declaration of Independence and friend of Franklin, presented this concept in a pamphlet published in early 1787:

For the purpose of diffusing knowledge, as well as extending the living principle of government to every part of the united states - every statecity — county - village — and township in the union, should be tied together by means of the post-office. This is the true non-electric wire of government. It is the only means of conveying heat and light to every individual in the federal commonwealth. Sweden lost her liberties, says the abbe Raynal, because her citizens were so scattered, that they had no means of acting in concert with each other. It should be a constant injunction to the postmasters, to convey newspapers free of all charge for postage. They are not only the vehicles of knowledge and intelligence, but the centinels of the liberties of our country. ${ }^{368}$

Rush's sentiments were not representative of wider public opinion, but other individuals may have shared them.

Probably a greater factor was the prestigious presence of Benjamin Franklin. Franklin sat in the Continental Congress that created the American post office. He produced the initial draft of the Articles of Confederation, which included a postal power. ${ }^{369} \mathrm{He}$ was willing to serve as postmaster general. He was at the convention that drafted the Constitution, and he supported ratification. His participation in all critical decisions must have helped the cause of the post office very much.

\section{B. The Constitutional Convention}

The proceedings of the Constitutional Convention refer only rarely to the Postal Clause. Apparently everyone assumed that the new government would continue to operate the Confederation postal service. A June 11, 1787 speech by James Wilson, as reported by Robert Yates, discloses the assumption: "He supposed that the impost will not be the only revenue - the post office he supposes would be another substantial source of revenue." 370 A postal power was probably implicit in Edmund Randolph's Virginia plan, which included a grant of authority "to legislate in all cases to which the separate States are incompetent." ${ }^{371}$ Similar "competence" language in Franklin's draft of the Articles had included the explicit example of the post office. ${ }^{372}$ William Paterson's New Jersey plan, essentially a strengthened

368 Benjamin Rush, Address to the People of the United States, American Museum (Jan. 1787), in Friends of the Constitution: Writings of the "Other" Federalists, 17871788 1, 4 (Colleen A. Sheehan \& Gary L. McDowell eds. 1998).

3692 J. Cont. Cong., supra note 1, at 195 (July 21, 1775).

3701 FARRAND, supra note 1, at 205 (June 11, 1787) (Yates).

371 Id. at 21 (May 29, 1787) (Madison).

372 Franklin's Articles of Confederation, art. V, in 2 J. ConT. Cong., supra note 1, at 195, 196 (July 21, 1775) ("The Congress shall also make such general Ordinances as tho' necessary to the General Welfare, particular Assemblies cannot be competent to; viz. Those that may relate ... to the Establishment of Posts"). 
version of the Articles of Confederation, included a postal power with revenue as a principal goal:

Resd. that in addition to the powers vested in the U. States in Congress, by the present existing articles of Confederation, they be authorized to pass acts for raising a revenue ... by a postage on all letters or packages passing through the general post-Office, to be applied to such federal purposes as they shall deem proper $\&$ expedient . ... ${ }^{373}$

A constitutional plan of uncertain date traditionally ascribed to South Carolina's Charles Pinckney also featured the enumerated power "of establishing PostOffices." 374

The next reference to the post office in convention records was a June 27, 1787 speech by Luther Martin, who also spoke of the subject in a revenue context. ${ }^{375}$ On July 26 , the convention adjourned and committed its resolutions to a five-member Committee of Detail charged with producing a draft constitution. Committee member Edmund Randolph produced an initial outline for his colleagues. The convention had produced no resolution specifically authorizing a post office, but Randolph's outline included an enumerated legislative power "To establish post-offices." ${ }^{376}$ The committee's final draft, presented on August 6, provided, "The Legislature of the United States shall have the power . . .To establish Post-offices." ${ }^{377}$

Nothing in the ensuing debate is recorded about the postal power until August 16, when Elbridge Gerry of Massachusetts moved to add "and post-roads." John Francis Mercer of Maryland seconded Gerry's motion. ${ }^{378}$ Neither Gerry nor Mercer were advocates for a strong national government, and during the ratification debates both opposed the Constitution. Their motion foreshadows support for a central post office even among Antifederalists.

The state-by-state voting on the proposed amendment to add post roads was close (six states to five), but does not display any particular pattern. ${ }^{379}$ No debate is recorded, so one can only guess at the reasons pro and con. Perhaps the supporters wished to clarify that power to establish post offices included authority to establish post roads. Perhaps some dissenters thought the point was obvious and that no

173 FARRAND, supra note 1, at 243 (Jun. 15, 1787) (Madison).

$3742 \mathrm{id}$. at 135 (Committee of Detail records).

$3751 \mathrm{id}$. at 442 (Jun. 27, 1787) (King) ("Congress could not raise a penny except agreeably to Rule of Taxation in the 8th Art-not even from the Post Office").

$3762 \mathrm{id}$. at 144 (Committee of Detail records). Other documents considered by the committee also refer to the post office. $2 \mathrm{id}$. at 157 (reproducing James Wilson's extract of the New Jersey Plan); id. at 167-68 ("to establish Post-offices") (Wilson's extract of the Pinckney Plan).

3772 id. at 181-82 (Aug. 6, 1787).

3782 FARRAND, supra note 1, at 308 (Aug. 16, 1787) (Madison).

$379 I d$. at 308 (Aug. 16, 1787) (Madison). Voting in favor were Massachusetts (Gerry's state), Maryland (Mercer's state), Delaware, Virginia, South Carolina, and Georgia. Voting against were New Hampshire, Connecticut, New Jersey, Pennsylvania, North Carolina. There were large and small states on both sides. There were also states with a developed road system on both sides and states with large undeveloped tracts on both sides. 
clarification was needed. Perhaps other dissenters feared Congress might create a British-style transportation monopoly.

Until July 17, 1787 advocates of a strong central government were in control of the federal convention. After that date, the convention usually resisted efforts to add federal powers. ${ }^{380}$ This generalization holds for all efforts to augment the postal power beyond the post road addition. The delegates rejected an effort (possibly by Charles Pinkney) $)^{381}$ to empower Congress " $[\mathrm{t}]$ o regulate Stages on the post roads." 382 The motion was sent to the Committee of Detail and never re-emerged. Gerry moved "to provide for public securities for stages on post-roads. ${ }^{383}$ It is unclear what this meant (perhaps armed guards or bonds to finance construction), but the motion was similarly committed, and not seen again. ${ }^{384}$ On August 20, Gouverneur Morris proposed to establish a "secretary of domestic affairs" whose duties would have included, among many others, "the opening of roads and navigations, and the facilitating communications thro' the U.States." ${ }^{385}$ This motion also was interred in the Committee of Detail. On September 14, Franklin sought to add to the postal clause "a power to provide for cutting canals where deemed necessary." 386 After unsuccessful efforts to expand this language further, the entire motion went down. ${ }^{387}$

The framers' rejection of proposals pertaining to stage carriages can be read two ways: (1) The framers may have viewed them as superfluous, because post-road authority always had included regulating vehicles on the road, or (2) the framers may have wanted to constrain federal power over post roads more narrowly than in Britain. The former is more probable, if only because, in the absence of contrary evidence we should presume that people as lawyerly as the framers wanted to retain what was familiar. As far as I know, there is no contrary evidence.

\section{The Ratification Era: 1787-90}

\section{A. RATIFICATION-ERA EVIDENCE}

The Constitution was signed on September 17, 1787. Convention president George Washington transmitted it to Congress, which sent it to the states for ratification. Each state legislature eventually called a popular ratifying convention to consider the document. All ratified. Rhode Island was the last to do so-on May 29, 1790. Thus, the ratification era extended from September 17, 1787 to May 29, $1790 .^{388}$ Ratification-era evidence of the Postal Clause's meaning is not copious. This Part V

\footnotetext{
380 Natelson, Enumerated, supra note 1, at 473 (marking July 17 as "the high tide of nationalization").

3812 FARRAND, supra note 1, at 325 n.4 (Aug. 18, 1787) (Madison).

382 Id. at 326.

383 Id. at 328.

384 Id. at 328.

385 Id. at 342-43 (Aug. 20, 1787) (Madison).

386 Id. at 615 (Sept. 14, 1787) (Madison).

387 Id. at 616 (Sept. 14, 1787) (Madison).

388 See 13 Documentary History, supra note 1, at xl - xlii (containing a chronology of events).
} 
arranges what we do have: (1) Material from the debates over ratification within the state conventions and among the general public, (2) proceedings in the Confederation Congress, and (3) proceedings in the first session of the First Federal Congress.

\section{B. The Ratification Debates in State Conventions and in Public}

In one respect, the debates over the Postal Clause in the ratifying conventions and among the general public were similar to those in the Constitutional Convention: There was some controversy, but not very much. Both Federalists ${ }^{389}$ and Antifederalists ${ }^{390}$ generally approved of the Postal Clause. Antifederalists sometimes cited the post office as a power the central government ought to possess, ${ }^{391}$ as opposed to others it ought not possess. The Federalists constricted the scope of potential controversy by distinguishing post roads from other roads, representing that only the state governments would exercise jurisdiction over the latter. ${ }^{392}$

Some dissention arose at the margin. At the New York ratifying convention, Samuel Jones, a state legislator, offered an amendment that would narrow the scope of the term "establish:"

Resolved . . . that the power of Congress to establish post-offices and post-roads is not to be construed to extend to the laying out, making, altering, or repairing high ways, in any state, without the consent of the legislature of such state..$^{393}$

389 E.g., Thomas McKean, Speech to the Pennsylvania ratifying convention, in 2 DOCUMENTARY History, supra note 1, at 415 (Nov. 28, 1787) ("The punishment of forgery and the establishment of post offices and post roads are subjects confessedly proper to be comprehended within the federal jurisdiction"); Cumberland Gazette, Nov. 15, 1787, in 4 Documentary History, supra note 1, at 245-46 (pointing out that congressional jurisdiction over the post office was granted by the Articles of Confederation); THE Federalist No. 40, supra note 1, at 202 (James Madison) ("Do these fundamental principles require particularly, that no tax should be levied without the intermediate agency of the States? The confederation itself authorises a direct tax to a certain extent on the post-office"); THE Federalist No. 42, supra note 1, at 222 (James Madison) ("The power of establishing post-roads, must in every view be a harmless power; and may perhaps, by judicious management, become productive of great public conveniency. Nothing which tends to facilitate the intercourse between the States, can be deemed unworthy of the public care.").

390 E.g., Federal Farmer, Letter I, Oct. 8, 1787, in 14 Documentary History, supra note 1, at 18 (same); Federal Farmer, Letter III, Oct. 10, 1787, in 14 Documentary History, supra note 1 , at 30,35 (same).

391 E.g., Samuel Chase's Objections, Apr. 24-25, 1788, in 12 Documentary History, supra note 1, at 641 (citing the post office as an appropriate congressional power). Antifederalists generally looked favorably on the post office as a source of revenue. Id. at 642; Melancton Smith, Speech to the New York Ratifying Convention, Jun. 27, 1788, 22 Documentary History, supra note 1, at 1931) ("The genl. govt. will have a certain \& very productive revenue from impost \& post office"); John Lansing, Jr, Speech to the New York Ratifying Convention, in id. at 2020 (same).

392 Natelson, Enumerated, supra note 1, at 488.

39322 Documentary History, supra note 1, at 2077 (Jul. 2, 1788) (Chiles, Debates). 
The proposal was not adopted, and may have may provoked amusement among those who thought it querulous. ${ }^{394}$ This rejection did not prevent Jones from supporting the Constitution, and other objections to the postal power are hard to find. ${ }^{395}$

If the ratification era witnessed little controversy about the Postal Clause as such, it witnessed a raging controversy over the post office itself. Some people were convinced their mail was being interrupted or opened and scrutinized, ${ }^{396}$ but far more were angry over a fall-off in postal reliability. The fall-off was real, an unintended consequence of Postmaster General Hazard's efforts to improve service. ${ }^{397}$

On November 2, 1786, Hazard had written to Congress about postal contracts for the calendar year 1787. He recommended that Congress continue to contract with stage coaches for mail delivery from New York to points south. However, he requested authority to revert to post riders for routes from New York through New England. ${ }^{398}$ Hazard detailed concerns of cost, reliability, and scheduling leading to his recommendation. ${ }^{399}$

Congress made no change for calendar year 1787. On October 12, 1787, Hazard renewed his request for calendar $1788 .{ }^{400}$ Three days later, Congress granted it. ${ }^{401}$

The ensuing change probably did not cause major kinks in letter delivery, but the results for newspapers turned out to be very bad. Stagecoaches had carried newspapers

394 N.Y. Daily Advertiser, Jul. 8, 1788, in 22 Documentary History, supra note 1, at 2079, 2080 (claiming Jones's proposal was greeted with laughter).

39523 Documentary History, supra note 1, at 2323 (Jul. 26, 1788) (Convention Journal); but see $2 \mathrm{id}$. at 507 (Dec. 5, 1787) (notes of James Wilson) (recording the complaint of Pennsylvania Antifederalist Robert Whitehill that "Even post roads are in the power of Congress.').

396 George Washington to the Marquis de Lafayette, Feb. 7, 1788, 8 Documentary History, supra note 1 , at 355 :

As to my sentiments with respect to the merits of the new Constitution, I

will disclose them without reserve (although by passing through the Post

offices they should become known to all the world) for, in truth, I have nothing to conceal on that subject."

See also Letter from Richard Henry Lee to Samuel Adams (Oct. 27, 1787), in 13 DoCUMENTARY History, supra note 1, at 484 (stating, in a letter carried by Elbridge Gerry, "Our mutual friend Mr. Gerry furnishes me with an opportunity of writing to you without danger of my letter being stopt on its passage, as I have some reason to apprehend has been the case with letters written by me and sent by the Post."); Letter from William Ellery to Benjamin Huntington (Jun. 7, 1788), in 26 DocumENTARY HistoRY, supra note 1, at, 1037 ("By some bad conduct of the Post master at Little Rest your letter of the $22 \mathrm{~d}$. of May did not come to hand timely enough to be answered in my last of the 1st. of June.-This is not the first time that he has been guilty of mal-conduct.").

397 The controversy is summarized and relevant documents reproduced in Appendix II, 16 DOCUMENTARY History, supra note 1, at 540 and JAFFe, supra note 1, at 84-8. Jaffe's narrative leans against Hazard, depicting him as having bad judgment and a personal antipathy to stage coaches. I do not share this view.

39831 J. Cont. Cong., supra note 1, at 922-23 (Nov. 2, 1786).

399 See also Letter from Ebenezer Hazard to Jeremy Belknap (May 17, 1788), in 16 DocUMENTARY History, supra note 1, at 593, 594 (explaining reasons for using riders rather than coaches).

40033 J. Cont. Cong., supra note 1, at 672 (Oct. 12, 1787).

401 Id. at 684 (Oct. 15, 1787) ("Resolved That the postmaster general be and he is hereby authorised to contract for the transportation of the mail for the year 1788 by stage carriages or horses as he may judge most expedient and beneficial; provided that preference is given to the transportation by stages to encourage this useful institution"). 
from publisher to publisher without charge, ${ }^{402}$ but post riders insisted on payment. ${ }^{403}$ This seems only fair, as John Jay recognized at the time, ${ }^{404}$ but the publishers were unhappy about having to pay. Moreover, post riders, even when compensated, proved undependable. Newspapers are bulkier than letters, and there is less room atop a horse than in a coach. Sometimes riders threw papers away en route. ${ }^{405}$ Sometimes they sold them for profit rather than delivering them properly. ${ }^{406}$

Complaints about unreliable delivery came from both sides of the constitutional controversy. Some (not all) ${ }^{407}$ Antifederalists saw it as the product a Federalist plot $^{408}$ whereby the post office would obstruct opposition papers while allowing Federalist papers to pass freely. ${ }^{409}$

By March, 1788, the charges against the post office had become very numerous. Hazard believed they justified response. He issued a public letter itemizing a series of supposed facts:

That the post-office was established for the purpose of facilitating commercial correspondence; and has, properly speaking, no connection with news-papers, the carriage of which was an indulgence granted to the post-riders, prior to the revolution in America:

That the riders stipulated with the Printers for the carriage of their papers, at a price which was agreed upon between them; and this price was allowed as a perquisite to the riders ...

That news-papers have never been considered as a part of the mail, nor (until a very few years) admitted into the same portmanteau with it; but were carried in saddle-bags, provided for that purpose, by the riders, at their own expence:

402 JAFFe, supra note 1 , at 86.

4032 Documentary History, supra note 1, at 643 (editor's note).

404 Letter from John Jay to George Washington (Sept. 21, 1788), in 23 DocumentaRY HisTORY, supra note 1, at 2472.

40516 Documentary History, supra note 1, at 541 (Appendix II).

406 Stoppage of Newspapers, Mass. Centinel, May 7, 1788, in 16 Documentary History, supra note 1, at 589, 590 (detailing misdeeds of post riders).

4072 id. at 644 (editor's note).

408 The controversy was provoked by a Pennsylvania Antifederalist writing under the pen name of "Centinel." See, e.g., Centinel, Letter IX, Phila IndePendent Gazetteer, Jan. 8, 1788 , in $15 \mathrm{id}$. at 308, 310:

[D]uring almost the whole of the time that the late convention of this state were assembled, the newspapers published in New-York, by Mr. Greenleaf, which contains the essays written there against the new government, such as the patriotic ones of Brutus, Cincinnatus, Cato, \&c. sent as usual by the printer of that place, to the printers of this city, miscarried in their conveyance ... and I stand informed that the printers in New-York complain that the free and independent newspapers of this city do not come to hand; whilst on the contrary, we find the devoted vehicles of despotism pass uninterrupted.

See also Centinel, Letter XI, Phila Independent Gazetteer, Jan. 16, 1788, in 15 id. at 386.

409 E.g. A Correspondent, Phila. Independent Gazetteer, Apr. 15, 1788, in 16 id. at 584. 
That, to promote general convenience, the post-masters (not officially) undertook to receive and distribute the news-papers brought by the riders, without any other compensation for their trouble than the compliment of a newspaper from each printer:

That, although the United States in Congress assembled, from an idea that beneficial improvements might be made in the transportation of the mail have directed alterations as to the mode of carrying it; yet they have not directed any to be made in the custom respecting newspapers:

And, That the post-master-general has given no orders or directions about them, either to the post-masters, or to the riders. From this succinct state of facts the post-master general apprehends it will clearly appear, that so far as the post office is concerned, the carriage of news-papers rests exactly on its original foundation; and that the attempts to excite clamors against the department must have some other source than a failure in duty on the part of the officers. ${ }^{410}$

This response was politically inept. It conveyed a tone sounding in arrogance, doubly so because it came from a person who was supposed to be a public servant. Furthermore, at least two of Hazard's "Thats" were not strictly accurate. Congress had not "directed" a change in the mode of carriage. Congress had authorized it at Hazard's request. Also, his claim that the post office was primarily for "commercial correspondence" was overstated. Opponents had no trouble shredding Hazard's defense. ${ }^{411}$

Adding to Hazard's difficulty is that he had annoyed people who purchased ink by the barrel. ${ }^{412}$ As purveyors of the written word, newspapermen were well situated to air complaints about the loss of their privileges. With some fairness, they could point out that even the British imperial post had permitted each printer to send one copy of each edition gratis to every other printer. With less justification, they pressed the Antifederalists' claim that public service was the primary reason for the post office..$^{413}$

41016 id. at 567-68 (Mar. 19, 1788).

411 A True Federalist, Mar. 25, 1788, in $16 \mathrm{id}$. at 569. The author reproduced in his response, $i d$. at 571, the resolution of Congress that authorized, but did not require the postmaster general to revert to post riders. See also Algernon, Phila. Independent GazetTeer, Apr. 10,1788 , in 16 id. at 582.

412 "Never pick a fight with people who buy ink by the barrel" - attributed to Mark Twain.

413 E.g., Manco, Maryland J., Mar. 18, 1788, in 16 Documentary History, supra note 1, at 561:

The News-Papers are the best vehicles of intelligence and information, respecting public affairs, to the people at large; and to stop their free circulation, is an act of injury and insult to the citizens of these United States. At no time can it be more necessary to keep open the channels of communication than at the present moment. The great motive for erecting the present Post-Office in America, was to promote the public good, by facilitating a constant and speedy conveyance of public despatches and private letters; and the incidental revenue arising from the latter, was but a secondary object.

See also A True Federalist, N.Y. J., Mar. 25, 1788, in 16 id. at 569; Phila. IndePENDEnT 
What could be more in the nature of public service than distributing newspapers?

\begin{abstract}
The stopping of public newspapers, in a free country, is an outrage upon all mankind, because it interrupts business, and foils the public in general of the only easy and expeditious mode of communicating important events and sentiments.- In them we find many interesting thoughts in religion, morals, politics, law, physic, agriculture, and commerce-by them we learn the state of foreign nations and foreign affairs - the various things that concern domestic oeconomicks, as well as the casualties of neighbourhoods. The merchant learns the general state of trade, hears the prices current, knows his losses in every quarter of the globe- thus he and the insurer are mutually advantaged and do mutual benefit to the community. The artist hears of employ or presents an advertisement of the various things he has for sale. The learned hears of new publications - their vent is increased — and innumerable advantages are extended to all. ${ }^{414}$
\end{abstract}

I have not found any printer who admitted at this juncture that he produced his papers for profit, or that he could have secured stage coach distribution merely by paying for it. ${ }^{415}$

The controversy is notable from the constitutional perspective in that even amid sharp debates over the Constitution, no one questioned the propriety of the Postal Clause, or argued that postal service should not be a government monopoly. All recorded complaints were about the quality of the service only.

\title{
C. Ratification-Era Proceedings in the Confederation Congress
}

The ratification-era record of the Confederation Congress can be summarized in a short sentence: Congress opted for the status quo. During this period, Congress spent perhaps more time on postal matters than in any comparable period, but it did nothing that would alter public understanding of what it meant "to establish Post Offices and post Roads."

Thus, in the fall of 1787, Congress remitted a breach-of-contract penalty for a contractor and authorized him to switch from coaches to horses. ${ }^{416}$ It debated delivery routes, ${ }^{417}$ entertained a report from Postmaster General Hazard on southern routes, ${ }^{418}$ opened the contracting process for $1788,{ }^{419}$ and reduced postage rates in hope of increasing business. ${ }^{420}$

GAZETTEer, Apr. 21, 1788, in 16 id. at 587.

414 New Hampshire Spy, Mar. 28, 1788, in 16 id. at 577. See also Mentor, Petersburg VA. GazetTe, Apr. 3, 1788, in 16 id. at 578 (containing another panegyric to newspapers coupled with an attack on the post office).

415 The campaign of newspapermen for a compliant post office is the theme of Adelman, supra note 1.

41633 J. Cont. Cong., supra note 1, at 533 (Sept. 25, 1787).

417 Id. at 647-49 (Oct. 10, 1787).

418 Id. at 671-73 (Oct. 12, 1787).

419 Id. at 684 (Oct. 15, 1787).

420 Id. at 695 (Oct. 20, 1787). 
During 1788, most activity was of the same kind. ${ }^{421}$ In an effort to quiet the newspaper delivery controversy, the committee on post offices recommended allowing publishers to exchange papers free of charge, ${ }^{422}$ but Congress took no action. Congress also took no action on the pending revision of the postal ordinances. ${ }^{423}$ A congressional committee determined that state executives had no authority to open the mail. ${ }^{424}$

Perhaps the most interesting development in 1788 was a harbinger of future patronage battles: A debate erupted among Pennsylvania, Massachusetts, and Delaware delegates over which states would obtain new postal routes. ${ }^{425}$

A 1788 report from the post office committee summarized the condition of the postal system. ${ }^{426}$ The staff consisted of the postmaster general, one assistant, and 69 deputy post masters, one for each office. Deputies were paid a commission of 20 percent of the postage on all letters delivered. Mail delivery was contracted out rather than entrusted to employees. Routes south of Virginia, where population was diffuse and delivery costs were high, ${ }^{427}$ ran a financial deficit. Northern routes more than made up the difference. At least since 1785, the office had been a profitable enterprise, and had paid substantial sums to the treasury ${ }^{428}$ despite the revenue drain from illegal competition and franking. ${ }^{429}$ During 1788 , the office had managed to cut delivery costs considerably.

The committee commended the post office for its contracting standards and the extremely low rate of contractual default.

\section{Ratification ERa Proceedings in the First Federal Congress}

When the First Federal Congress convened in April, 1789, ${ }^{430}$ about a year remained in the ratification era, for neither North Carolina nor Rhode Island had entered the union. The new government did nothing during that period that would have changed the public meaning of the Postal Clause. It seems to have been taken for granted that the postal system would serve its traditional role as a medium for governmental intelligence, a source of revenue, and an aid to commerce. There

421 E.g., 34 J. Cont. Cong., supra note 1, at 65-66 (Feb. 27, 1788) (authorizing posts for the transportation of mail between Philadelphia and Pittsburgh); 34 id. at 66-67 (Feb. 27,1788 ) (entertaining the postmaster's request for authority to cancel an unfulfilled contract); $34 \mathrm{id}$. at 76-77 (Mar. 3, 1788) (receiving postmaster general's report on the Pittsburgh route); $34 \mathrm{id}$. at 81-82 (Mar. 4,1788 ) (receiving his report on a proposed Maine route); $34 \mathrm{id}$. at 142-44 (May 6, 1788) (receiving his report on a damaged mail shipment); $34 \mathrm{id}$. at 273-74 (Jul. 1, 1788) (authorizing bidding for mail contracts).

$42234 \mathrm{id}$. at 144 (May 7, 1788); 16 Documentary History, supra note 1, at 589.

423 Supra notes 308-310 and accompanying text.

42434 J. Cont. Cong., supra note 1, at 232 (Jun. 13, 1788) \& 239 (Jun. 18, 1788).

${ }^{425}$ Id. at 161-63 (May 20, 1788) \& 174 (May 22, 1788).

426 Id. at $462-65$ (Aug. 27, 1788).

427 The committee also noted that the cost of delivery per mile was "generally greater at the Southward than Eastward." $34 \mathrm{id}$. at 464 (Aug. 27, 1788).

428 See $34 \mathrm{id}$. at 463-64 (setting forth the statistics).

429 Supra notes 316-329 (describing losses from franking).

430 The House attained a quorum on April 1 and the Senate on April 6. 1 Annals of Cong. $16 \& 100$. 
was no mention of the "public service" theory formerly promoted by newspaper publishers and Antifederalists.

Congressional attention was mostly on revenue. ${ }^{431}$ The executive branch was similarly focused. The new postmaster general, Samuel Osgood, worked directly under Secretary of the Treasury Alexander Hamilton, and on January 20, 1790 Hamilton provided Congress with a report by Osgood. ${ }^{432}$ The report addressed several topics, but Osgood viewed them principally in the light of revenue.

Osgood rejected the idea that newspapers should travel free, advocating a charge of one or two cents on each. ${ }^{433} \mathrm{He}$ did cite a goal of easing communicationbut principally between remote regions and the national capital. ${ }^{434}$ In other words, the Washington administration was still thinking of the post office "intelligence" function as primarily serving the government. Moreover, Osgood assured Congress that contact between the capital and remote regions could be accomplished without diminishing revenue. ${ }^{435}$

To the extent that Osgood proposed reform, he recommended changes that would have moved the American system closer to the British model. He favored strengthening the postal monopoly by cracking down on competition. ${ }^{436} \mathrm{He}$ suggested exerting more control over the transportation network by barring from the post roads any coach not commissioned by the postal service ${ }^{437} \mathrm{He}$ recommended that Congress delegate to his department power to establish new post offices and post roads. ${ }^{438}$

Congress's September, 1789 legislation "for the temporary establishment of the Post Office" 439 provided for a postmaster general and assistants in the new executive branch, and added that "the regulations of the post-office shall be the same as they last were under the resolutions and ordinances of the late Congress." 440 This law was "to continue in force until the end of the next session of Congress, and no longer"- that is, until 1790. But Congress extended it in 1790 and again in 1791.441

431 E.g., 1 Annals of Cong. 316 (May 9, 1789) (quoting Theodorick Bland on the post office as a source of revenue); id. 1566-67 (April 1, 1790) (quoting Jeremiah Wadsworth in discussing postal revenue as part of a review of the secretary of the treasury's report); $i d$. at 1579 (Apr. 13, 1790) (quoting remarks by Hugh Williamson on postal revenue). See also id. at 1936 \& 1938 (Jan. 31, 1791) (quoting post-ratification statement by Hugh Williamson and James Jackson on the revenue effects of different postal routes).

432 Postmaster General's Report, Jan. 20, 1790, in 1 ANNALS OF Cong. 2161.

4331 AnNals of Cong. 2163.

434 Id. at 2164. This lends content to a sentence in President Washington's admonition that Congress direct its attention to post offices and post roads to "facilitat[e] the intercourse between the distant parts of our country." 1 AnNALS OF Cong. 970.

435 Id. at 2164 .

$436 I d$. at 2166 (extending prohibition on carriage of letters for those who carried without compensation and defining postal crimes more carefully).

437 Id. at 2165 .

438 Id. at 2167 .

439 So characterized $i d$. at at 82 (Sept. 15, 1789); id. (Sept. 17, 1789); id. at 927 (Sept. 16, 1789); id. at 928 (Sept. 17, 1789); id. at 1027 (June 21, 1789) and passim.

440 Act of Sept. 22, 1789, ch. 16, 1 Stat. 70.

${ }^{441}$ Act of Aug. 4, 1790, ch. 36, 1 Stat. 178; Act of Mar. 3, 1791, ch. 23, 1 Stat. 218. The 1791 extension also expanded franking privileges and authorized a postal route from Albany, New York to Bennington, Vermont. Id. $\S \S 2 \& 3$. 
Congress may have failed to adopt comprehensive postal legislation from a sense that the office was working well enough to allow it to concentrate on other priorities. The reason usually cited, however, is that Senate and House were divided on Osgood's request that Congress delegate to him authority to designate post roads. It is true that, while other issues arose in congressional debate, ${ }^{442}$ delegation was the principal sticking point. ${ }^{443}$

\section{The Original Meaning of the Postal Clause}

\section{A. Questions RAISED}

One way to clarify the original meaning of the Postal Clause is to answer several questions repeatedly posed about the scope of the postal power: ${ }^{444}$

- What was a "post road?" Was it any road over which the mail was carried?

- What did "establish" mean? In particular, did the power to "establish" post offices include authority to define and provide for prosecution and punishment of postal crimes?

- Did the Postal Clause permit the post office to pursue entrepreneurial opportunities? If so, which ones? ${ }^{445}$

- Did the Clause authorize constructing new roads and facilities or merely designating existing ones?

- If the power extended to constructing roads, did it include eminent domain?

The material presented heretofore in this Article enables us to answer most of these questions. The question pertaining to eminent domain requires additional discussion, presented below. ${ }^{446}$

\section{B. What WAS A "POST ROAD?"}

Before answering the first question, it may be helpful to summarize some of the findings already presented in this Article.

442 E.g., 1 Annals of Cong. 1580 (Apr. 13, 1790) (discussing whether "farming" [contracting out] should be permitted); 13 FIRST CONGRESS, supra note 1, at 1570 (1995) (Jun. 15, 1790 discussion of whether private stage passengers should be permitted to carry letters).

${ }^{443}$ Currie, supra note 1, at 628-32 (describing the debate in the first and second federal Congresses); Mashaw, supra note 1, at 1293-94. See also infra Part VII.B.

${ }^{444} C f$. Rogers, supra note 1 , at $10 \& 31-36$.

445 Elaine C. Kamarck, Delaying the Inevitable: Political Stalemate and the U.S. Postal Service 10-11 (Brookings Inst. 2015) (discussing postal initiatives toward banking, parcel post, and telephone and telegraph in the early twentieth century and grocery delivery in 2014).

446 Infra Part VI.E. 
During the founding era, post offices and post roads were not separate institutions. They comprised parts of single system, and the Postal Clause granted power to create and regulate it. The system was a network designed primarily to (1) facilitate information flow between the central government and the public at large (including government intelligence and propaganda), (2) raise revenue, and (3) facilitate trade and commerce. Providing a means of private correspondence and information dissemination was a subsidiary goal

The activities of a postal system included carriage of persons, freight, and letters. For international and coastal transportation and delivery, the system relied on a fleet of packet boats. ${ }^{477}$ For inland transportation and delivery, it relied principally on post roads.

A post road was a highway punctuated by posts - and thereby distinguished from public ways of other kinds. ${ }^{448}$ Each post was overseen by a post master who carried out his official functions in a post office. A post marked the end and beginning of successive stages. A post (sometimes also, confusingly called a "stage") was where traffic switched from one stage to another. It was a site for feeding, stabling, exchanging and renting horses; storing, exchanging, and renting vehicles; accepting letters and packages from an earlier courier and handing them to the next; and assessing payment for carriage, rental, and tolls. Many, if not most, posts provided amenities such as taverns, inns, and newspapers.

We are now prepared to answer the first question. A post road was not so called because the mail was carried over it. Precisely the reverse was true: The mail was called the "post" because it was carried principally on the post road. The post road was the central feature of a postal system, and it gave its name to the freight, to post offices, post boys, and riding post. If a post boy carried letters from the post office across city streets to individual addresses, as King's Bench required in Smith v. Powdich, ${ }^{449}$ that did not convert city streets into post roads.

Of course, a particular post or stage might lack one or more facilities available at others, and a postal system might have more or fewer features than others. However, the scope of the constitutional phrase "Post Offices and post Roads" cannot be defined by the activities of any particular postal institution at any one time, but by what the founding generation understood could be within a postal system's purview. In essence, this comprised the maintenance of packet boats, the construction and care of post roads, and the carriage and delivery of humans, animals, letters, and freight by means of packet boats and post roads.

\section{What DID "ESTABLISH" MEAN, aNd DID the POWER to "ESTABLISH" a Postal System Include Defining and Punishing Postal CRimes?}

To "establish" a postal system, or one of its components, comprehended all actions necessary to make the system or component work: In the case of the postal system, this included purchasing, maintaining, and operating packet boats; laying out, constructing, and maintaining posts, toll gates, and post roads; hiring and directing

447 LEwINS, supra note 1, at 94-95.

448 Cf. Natelson, Enumerated, supra note 1, at 480 n.65 (referring to "roads [except post roads"] \& 488 (similar distinction).

449 (K.B. 1774) 1 Cowp. 182, 98 Eng. Rep. 1033. 
postal employees and contractors; specifying the rules for travel, ${ }^{450}$ carriage, pickup and delivery; issuing and selling stamps and passage rights; obtaining and renting out horses and vehicles; and so forth. To "establish" postal institutions encompassed granting them and their employees monopoly status and other privileges, ${ }^{451}$ as well as granting privileges to persons and institutions against the postal system, such as the frank.

In Anglo-American practice, "establishing" a postal system always included defining and providing for prosecution and punishment of postal crimes. This was not a mere incidental power memorialized by the Necessary and Proper Clause, ${ }^{452}$ as some have assumed. ${ }^{453}$

\section{Did the Postal Clause Permit the Post Office to Pursue ENTREPRENEURIal OPPORTUNITIES? IF SO, Which ONES?}

Entrepreneurial activities engaged in by the post office, or proposed for it, have included the parcel post, banking, job placement, telephone and telegraph services, and, most recently, delivery of groceries. Assessing which of these is within or without the original meaning of the Postal Clause requires that we consider what the founding generation understood a postal system to be: a system of staged roads, vehicles, packet boats, and associated institutions for transport of letters, animals, goods, and persons. Certainly, this grant was not limited to the technology of the founding era: Congress could replace horses with motor vehicles, gravel with asphalt, and sailing vessels with diesel or atomic power. But the grant did not encompass establishing or operating businesses the Constitution's ratifiers would have thought quite distinct from postal services.

450 Thus, the decision of the Committee of Detail at the Constitutional Convention not to include the phrase "to regulate stages on the post roads," Rogers, supra note 1, at 23, did not affect the scope of the Clause.

$451 C f$. Rogers, supra note 1, at 41 ("Nor has there been any dispute as to the power of Congress to establish a monopoly by forbidding private postal enterprises").

452 U.S. Const., art. I, § 8, cl. 18 ("The Congress shall have Power . . To make all Laws which shall be necessary and proper for carrying into Execution the foregoing Powers, and all other Powers vested by this Constitution in the Government of the United States, or in any Department or Officer thereof.").

453 E.g., Andrew Koppelman, Bad News For Bank Robbers: The Obvious Constitutionality of Health Care Reform, 121 Y ALE L.J. ONLINE 1 (apparently assuming that defining postal crimes is an exercise of power under the Necessary and Proper Clause).

The assumption arises from language in McCulloch v. Maryland, 17 U.S. 316, 385 (1819) ("the power of establishing post-offices and post-roads, involves that of punishing the offence of robbing the mail"), the leading case on the Necessary and Proper Clause, coupled with the premise that the Clause substantively adds to the power to "establish." From a founding-era prospective, however, the Clause was merely a rule for interpreting the word "establish." The term "establish," if construed according to its original meaning, already included the power to create postal crimes. See also Robert G. Natelson, The Framing and Adoption of the Necessary and Proper Clause, in Lawson, ET AL., supra note 1, at 97-108 (2010) (collecting evidence showing that the Clause was understood during the ratification as merely a rule of construction). Modern readers are apt to misread Marshall's language if they are not aware that in his day the word "involve" could mean "include." Thomas Sheridan, A Complete Dictionary of the ENGLiSh Language (2d ed. 1789) (unpaginated) (defining "involve"). 
Except for the London penny post, ${ }^{454}$ the British and American post offices often carried large or usual items. That was the purpose of the stage wagon ${ }^{455}$ and one of the purposes of the packet boat. ${ }^{456}$ Congress's 1782 ordinance contained no limits on weight, other than those inherent in the cost of postage. There were no restrictions, other than those of practicality, on what was carried. British riders and stage coaches transported-indeed, in some cases franked-items as diverse as dogs and cattle; stockings, lace, and other clothes; medicines, tea, and bacon. ${ }^{457}$ It follows that parcel post and grocery delivery are within the original scope of the postal power.

On the other hand, nothing within the founding-era understanding of a postal system encompassed banking ${ }^{458}$ or job placement. The framers' refusal to add canals to the Postal Clause ${ }^{459}$ implies that it excludes non-road networks, such as telegraph and telephone services.

\section{E. Did the Clause Authorize Constructing NeW Roads and Facilities or MERELY DESIGNATING EXISTING ONES?}

Thomas Jefferson once suggested that "establishing" a post road was limited to merely designating which existing roads should be used for the transport of the mail - that the power to "establish" did not include building roads. ${ }^{460}$ The suggestion was perhaps whimsical or mischievous, for there is no support for such an interpretation other than Jefferson's prestige.

Just as "establishing" a postal system encompassed performing what was needed to create and regulate that system, founding-era sources show that "establishing" a road included whatever was necessary for bringing it into existence: planning, laying out, clearing, surfacing, and so forth. ${ }^{461}$

$\overline{454 \text { E.g., } 5 \text { Geo. i, c. } 21 \S 14 \text { (eliminating general practice of delivering bulky parcels }}$ in the penny post).

455 Lewins, supra note 1 , at 76.

456 Id. at 94-96.

${ }^{457} I d$. at 96 (listing items). The list also includes "Two maid servants going as laundresses to my Lord Ambassador Methuen"- whether indentured or free is not stated. Id.

458 In 1792, the British post office began to offer a money order service but this was, of course, after the Constitution was ratified. Additionally, money orders were then limited to soldiers and sailors who wished to send part of their pay home without entrusting coins or bank notes to the mail. LEwINS, supra note 1, at 152. It was not a general banking service.

459 Supra notes 386-387 and accompanying text.

460 Letter from Thomas Jefferson to James Madison (Mar. 5, 1796), in The Founders' Constitution (Philip B. Kurland \& Ralph Lerner eds. 1987), available at http://presspubs.uchicago.edu/founders/documents/a1_8_7s4.html (last visited Feb. 28, 2018) ("Does the power to establish post roads, given you by Congress, mean that you shall make the roads, or only select from those already made, those on which there shall be a post? If the term be equivocal, [\& I really do not think it so,] which is the safest construction?") (italics in original).

${ }_{461}$ Supra notes $252 \& 253$ and accompanying text. 


\section{F. Did the Grant of Power to Establish Post Roads Include an Incidental GRANT OF EMINENT DOMAIN AUTHORITY?}

In Kohl v. United States, ${ }^{462}$ the Supreme Court answered this question in the affirmative. The court noted that eminent domain was a prerogative of sovereignty during the founding era, and it identified the Fifth Amendment's Takings Clause as an acknowledgment that the federal government could condemn property. However, in a study published in 2013, Professor William Baude questioned this holding. ${ }^{463}$ Professor Baude argued that the founding generation would have deemed eminent domain a "great power" 464 _ Chief Justice John Marshall's term for what was more commonly called a principal or express power ${ }^{465}$-rather than one that could be merely incidental or implied. ${ }^{466}$ Because founding-era law required that a grant enumerate principal powers explicitly, ${ }^{467}$ Professor Baude concluded the Constitution's failure to enumerate the power of eminent domain meant it was not conveyed. ${ }^{468}$

Professor Baude's study focused primarily on developments well after the founding. His founding-era evidence was relatively slender, and some of it was equivocal, ${ }^{469}$ open to challenge, ${ }^{470}$ or dependent on inference or analogy. ${ }^{471}$ In my

91 U.S. 367, 368-73 (1875).

Baude, supra note 1.

Id. at $1755-61$.

McCulloch v. Maryland, 17 U.S. 316, 407 (1819).

466 Robert G. Natelson, The Legal Origins of the Necessary and Proper Clause, in Lawson, ET AL., supra note 1, at 60-68 (explaining the contemporaneous doctrine of principal and incidental powers).

467 Cf. McCulloch, 17 U.S. at 406-08 (stating that in a constitution it is sufficient to enumerate the great powers and leave the incidentals to inference); Robert G. Natelson, The Legal Origins of the Necessary and Proper Clause, in Lawson, ET AL., supra note 1, at 64 ("Although transfer of the principal automatically included the incident, grant of an incident, without more, did not carry the principal with it").

468 Baude, supra note 1, at 1745-61. Similarly, in 1808 Secretary of the Treasury Albert Gallatin contended that federal eminent domain required state consent. Albert GaLLATin, Report of the Secretary of the Treasury on the Subject of Public Roads and Canals 73 (1808). Gallatin provided no support for this statement.

469 Professor Baude seems to recognize its equivocal nature. E.g. Baude, id. at 175860 (relying on words and phrases such "it might suggest," "not the only plausible construction" and "suggests").

470 For example, Professor Baude observes that for the Crown to exercise eminent domain, "It had to be granted explicitly by Parliament, not carried through by implication." Baude, supra note 1, at 1756, citing Stoebuck, supra note 1, at 562-66. However, as Professor Stoebuck makes clear, eminent domain required a parliamentary grant because it was a purely legislative power and was not included among certain similar powers ordinarily encompassed by the royal prerogative. $I d$. at 564 . Obviously, the fact that eminent domain was legislative tells us nothing about whether it could be granted as an incident to other legislative powers.

471 E.g., Baude, supra note 1, at 1756-57 (arguing from analogies to the power to tax) and $i d$. supra note 1, at 1768 (noting that during the ratification debates Federalists represented that states would have exclusive power over land titles). I previously documented the same Federalist representations, Natelson, Enumerated, supra note 1, at 481-82, but I recognize that the Federalists could have been stating a general, not an invariable, rule. 
view, neither the Supreme Court's nor Professor Baude's treatment is sufficient to resolve this question.

During the eighteenth century, the exercise of eminent domain customarily accompanied construction and widening of roads and canals. Statutes empowering boards of trustees to undertake those activities routinely included grants of condemnation authority. ${ }^{472}$ However, custom alone did not determine whether a linked power was principal or incidental; it was principal if "worthy" enough to qualify as such. ${ }^{473}$

The fact that the drafters of road statutes took the trouble to enumerate eminent domain authority expressly is evidence that it was regarded as a principal, rather than incidental, power. However, parliamentary road statutes and the Constitution were very different kinds of documents. One expects a statute to itemize more than a constitution. ${ }^{474}$ Moreover, the grantees in most parliamentary road statutes were private trustees, ${ }^{475}$ but eminent domain was an incident of sovereignty. ${ }^{476}$ There was more need to mention it explicitly in a constitution than in a conveyance to nonsovereigns. So to answer our question, we need other forms of evidence.

The evidence falls into two broad categories. One consists of contemporaneous law books classifying fields of Anglo-American jurisprudence. Professor Herbert A. Johnson's survey of eighteenth century American law libraries provides evidence of which of these works were in common use on this side of the Atlantic. ${ }^{477}$ Their classification schemes tell us which topics were deemed more important (and therefore potentially "principal") and which were deemed less so (and potentially "incidental"). The other category of evidence consists of documents that, like the Constitution, granted legislative authority to new governments or government agents.

The most probative law books may have been the multi-volume digests or "abridgments" that sorted Anglo-American law into topics, subtopics, and lesser divisions. Probably the best, one of the most popular, and certainly the most current,

472 E.g., 33 Geo. 2, c. 56 (1759) (Alexander Kincaid, Edinburgh, 1775) at 21-23 (providing for exercise of mandatory sale in repairing and widening a road); 1 Geo. 3, c. 35 (1761) (published as An Act for Amending the Road from Sacred Gate ...), at 6-7 (providing for mandatory sale in improving a road); 18 Geo. 3, c. 75 (1778) (published as An Act for Making a Navigable Canal from the Town of Basingstoke ...), at 4-5 (providing for condemnation in construction of canal); 28 Geo. 3, c. 86 (1787) (published as An Act for Amending, Widening, and keeping in Repair, the Road from the Bottom of Whitesheet Hill ..."), at 12 (providing for condemnation in improving and widening a road); 31 Geo. 3, c. 94 (1790) (published as An Act for Making a new Road from Saint George's Gate..."), at 11-13 (providing for condemnation in constructing a road).

See also Stoebuck supra note 1, at 561n. 28 (citing colonial laws authorizing condemnation for roads).

473 Robert G. Natelson, The Legal Origins of the Necessary and Proper Clause, in Lawson, ET AL., supra note 1, at 61.

474 Cf. McCulloch, supra, 17 U.S. at 407 ("A constitution, to contain an accurate detail of all the subdivisions of which its great powers will admit, and of all the means by which they may be carried into execution, would partake of the prolixity of a legal code, and could scarcely be embraced by the human mind.")

475 See sources cited supra note 472.

476 Stoebuck supra note 1, at 559-60 (citing the views of leading contemporaneous commentators).

477 Johnson, Imported Treatises, supra note 1. 
was the 1786 edition of Matthew Bacon's A New Abridgment of the Law. ${ }^{478}$ An examination of this work shows that many of its first-order titles featured concepts corresponding to constitutional categories. ${ }^{479}$ Where they did not, it was often because the author divided topics at a lower level of generality. For example, the Constitution refers to "commerce," but Bacon split commerce into principal titles such as "carriers" and "fairs and markets." 480 Despite its frequent adoption of a lower order of generality, Bacon's Abridgment contains no title, or even subtitle, for eminent domain or for synonyms such as compulsory acquisition, compulsory powers, condemnation, expropriation, or taking. ${ }^{481}$

The other three among the four most popular digests - those by Knightly D'Anvers, Charles Viner, and John Lilly - similarly contained no first-order title for the subject. ${ }^{482}$

Also widely-used were "institutes." These were treatises surveying the entire scope of the law. The two eighteenth century institutes most generally held in America were William Blackstone's Commentaries, and Thomas Wood's Institute of the Laws of England. ${ }^{483}$ The Commentaries contained a short treatment of

478 Bacon's work appeared in ten of the 22 law libraries surveyed. JOHNSON, IMPORTED TREATISES, supra note 1, at 59. The abridgment by Knightly D'Anvers was more widely held (by thirteen libraries), but it had not been updated since 1737, id. at 17-18, and as far as I can ascertain, was never completed. My assessment that Bacon's digest was probably the best in its category is based on my own experience with such works over the last thirteen years.

479 Matthew Bacon, A New Abridgement of the Law (Dublin, 1786). The following headings, which are located in unpaginated portions of each volume, correspond to explicit constitutional categories:

Volume 1: bail (two headings), bankrupt, carriers (a division of commerce), courts and their jurisdiction in general, of the court of admiralty — with headings for many other judicial categories.

Volume 2: felony, fairs and markets (another division of commerce), fines and amercements, forgery, forfeiture, grants.

Volume 3: habeas corpus, highways, juries, merchant and merchandize [i.e., more commerce], offices and officers, pardon, piracy.

Volume 4: privilege, soldiers, statute.

$480 \quad I d$.

Volume 5: tender [of money], treason, trial.

${ }^{481}$ Cf. Stoebuck supra note 1, at 554 (listing some of these synonyms).

482 Johnson, Imported Treatises, supra note 1, at 59 sets forth the number of libraries for each of the following: Knightly D'Anvers, A General Abridgment of the Common LAW (2d ed. 1725-37) (3 vols.) (held by 13 of 22 law libraries surveyed); Charles VINER, A General Abridgment of LaW and Equity ( $1^{\text {st }}$ ed. 1742-45) (24 vols.) (held by nine libraries); John Lilly, The Practical Register, or a General Abridgment of the LaW (2d ed. 1745) (two vols.) (held by eight libraries).

Lists of topics in the D'Anvers and Viner works appear in unpaginated sections at the beginning of each volume.

483 Johnson, Imported Treatises, supra note 1, at 59 (indicating that Blackstone's Commentaries appeared in ten of 22 libraries, and Wood's Institute in eight).

I have not relied on Edward Coke's Institutes, which were widely held but already well over a century old. In any event, eminent domain and its synonyms do not appear as a title in eighteenth century editions of this treatise. EDWARD CoKE, THE FirST PART OF THE InSTITUTES OF THE LAWS OF ENGLAND (13 ${ }^{\text {th }}$ ed. 1788) (unpaginated table near the end of the volume); Edward Coke, the Second Part of the Institutes of the Laws of England 
eminent domain, referring to it as a legislative prerogative and using road-building as an example; however, Blackstone (or his publisher) did not think the concept worth an index entry. ${ }^{484}$ There was an index entry for "taking," but it referred the reader to felonious and unlawful takings, not to eminent domain. Wood's Institute featured no relevant entry. ${ }^{485}$

Founding-era legal dictionaries consisted of more than definitions. Their comprehensive entries made them akin to single volume encyclopedias. In America the most popular work of this kind - by a wide margin — was Giles Jacob's A New Law-Dictionary. ${ }^{486}$ Most of the leading nouns in the Constitution's enumeration of congressional powers ${ }^{487}$ also appear in Jacob's 1782 edition, either in the same form or in close variations: Among Jacob's entries were "tax," "debt," "money," "creditor," "commerce," "naturalization," "bankrupt," "coin," "counterfeits," "post," "pirates," "letters of marque," and "militia." Yet there is no entry for any of the synonyms for eminent domain other than "taking," ${ }^{888}$ and the two entries for "taking" referred to felonious and unlawful taking, as in Blackstone's index. References to eminent domain are likewise lacking in other contemporaneous law dictionaries. ${ }^{489}$

In sum, the classification schemes adopted by leading works of eighteenth century law imply that eminent domain was not a prominent legal concept. It surely did not rank with taxation, military affairs, or commercial regulation as a principal power in a grant of governmental authority.

Another form of evidence consists of contemporaneous documents that, like the Constitution, conveyed legislative authority to governments and governmental agents. Those most relevant to America were (1) colonial charters by which the British Crown empowered colony organizers, (2) commissions by which the Crown empowered colonial governors, and (3) founding-era state constitutions, by which the people of each state created new governments and granted power to them.

(unnumbered ed. 1797) (unpaginated tables near beginning and end of the volume); Edward Coke, The Third Part of the Institutes of the Laws of England (unnumbered ed. 1797) (same); Edward Coke, The Fourth Part of the Institutes of the Laws of ENGLAND (unnumbered ed. 1797) (same).

4841 William Blackstone, Commentaries * $135 ; 4 i d$. (unpaginated index).

485 Thomas Wood, An Institute of the Laws of England (10 ${ }^{\text {th }} \mathrm{ed} .1783$ ) (unpaginated table near the end of the volume).

486 The edition used in this search was Giles Jacob, A New Law-Dictionary $\left(10^{\text {th }}\right.$ ed. 1782). Johnson, Imported Treatises, supra note 1, at 61 , states that Jacob's dictionary in one edition or another was in twelve of 22 surveyed law libraries. Next in popularity was John Cowell's Interpreter, held by six libraries, tied with a Law-French dictionary.

487 Principally U.S. CONST. art. I, § 8, although other congressional powers are scattered throughout the document.

488 Id. (unpaginated).

489 John Cowell, A Law Dictionary, or the Interpreter of Words and Terms (Improved, enlarged ed. 1727) (held by six libraries); William Rastell, Les Termes de LA LeY (unnumbered ed. 1742) (held by four); Timothy Cunningham, A New and Complete Law-Dictionary (1783) (held by three); Thomas Blount, A Law Dictionary and GLOSSARY ( $3 \mathrm{~d}$ ed. 1717) (held by three). I also examined two dictionaries not on Professor Johnson's list, Anonymous, The Student's LaW-Dictionary (1740) and Richard Burn \& John Burn, A New Law Dictionary (1792), with similar results. 
English law recognized a subsidiary legislative authority within the royal executive's prerogative to govern conquered and unorganized territories. ${ }^{490}$ Thus, royal charters erecting colonial governments enumerated and conveyed legislative powers, usually to be exercised by the governor and council in conjunction with an elected assembly. Typically listed were taxation, ${ }^{491}$ legislation, ${ }^{492}$ commercial activities, ${ }^{493}$ land disposition, ${ }^{494}$ and creation of courts ${ }^{495}$ - all powers found in the Constitution. In no charter did eminent domain appear separately. Yet we know that colonial governments exercised eminent domain, ${ }^{496}$ so it must have been implied from the enumerated powers.

In 1688 the absolutist government of James II (1685-89) issued a commission to Edmund Andros as governor of the "Dominion of New England."497 The Dominion consolidated not only modern New England, but New Jersey and New York. In addition to granting executive and judicial authority, the commission granted Andros an expansive list of legislative powers. These included the power to make laws, impose taxes, appropriate funds, raise military forces, create courts, dispose of land, and provide for fairs, markets, ports, and similar instrumentalities of commerce. ${ }^{498}$ Eminent domain was not enumerated. This cannot be because the parties were ignorant of the subject. Only five years earlier eminent domain had been banned in New York by an instrument revoked when the Dominion was created. ${ }^{499}$ Thus, it is highly unlikely that the Crown intended to deny Andros authority to take land for improvements such as roads. That authority must have been implied in the enumerated grants.

In the century after the British evicted James II and the colonists disposed of Andros, the commissions of colonial governors became highly standardized. They

490 Campbell v. Hall, 98 Eng. Rep. 848 (K.B. 1774) (holding that the Crown may legislate for conquered territories until formally admitting English law and institutions into the territory, but not afterward). $C f$. U.S. ConsT. art. IV, § 3, cl. 2 ("The Congress shall have Power to dispose of and make all needful Rules and Regulations respecting the Territory ... belonging to the United States").

491 E.g., Mass. Charter (1691) ("And alsoe to impose Fines mulcts Imprisonments and other Punishments And to impose and leavy proportionable and reasonable Assessments Rates and Taxes"); Md. Charter, art. XVII (1632) ("Power . . . to assess and impose the said Taxes").

492 E.g., Ga. Charter (1732) (“. . full power and authority to constitute, ordain and make, such and so many by-laws, constitutions, orders and ordinances").

493 E.g., Pa. Charter (1681) (authorizing importation, creation of fairs, markets, and "Seaports, harbours, ... and other places, for discharge and unladeing of goods").

494 E.g., Ga. Charter (1732) (granting power to colonial common council to convey land). $C f$. U.S. Const. art. IV, $\S 3$, cl. 2 ("The Congress shall have Power to dispose of and make all needful Rules and Regulations respecting the Territory or other Property belonging to the United States. ..").

495 E.g., Ga. Charter (1732) ("to erect and constitute judicatories and courts of record, or other courts)."

496 Stoebuck supra note 1, at 561n. 28 (citing colonial laws authorizing condemnation for roads).

497 Commission to Sir Edmund Andros as governor of the Dominion of New England, in EHD, supra note 1, at 239.

498 Id.

499 The New York Charter of Liberties and Privileges (Oct. 30, 1683), in EHD, supra note 1, at 228, 230 (denying authority to dispose of land without the owner's consent). 
all enumerated legislative functions to be exercised in conjunction with an elective assembly. They all left eminent domain to implication. ${ }^{500}$

Between 1776 and May 29, 1790, when Rhode Island ratified the Constitution, all states except Connecticut and Rhode Island adopted new constitutions. The framers of these documents typically contemplated general purpose governments, so most state constitutions granted legislative authority in bulk rather than in enumerated detail. ${ }^{501}$ A partial exception was the Massachusetts Constitution of 1780, drafted primarily by John Adams, which conveyed to the legislature ("general court") authority to erect a judiciary, to tax, and to otherwise legislate. ${ }^{502}$ Eminent domain was not set forth explicitly. But it must have been implied from the principal grants, because another portion of the same document limited its exercise. ${ }^{503}$

It thus appears that the founding generation did not consider eminent domain to be a "great," or principal, power. There was no need for the Constitution's framers to enumerate it separately, because it was incidental to items they did enumerate. Among these was authority to "establish post Roads."

500 Anthony Stokes, A View of the Constitution of the British Colonies 150-64 (B. White 1783) (reproducing form commission) (available at http://books.google.com/books?id= VmNzusdnHlcC\&printsec $=$ frontcover \& $\mathrm{dq}=$ anthony+stokes\#PPP7,M1).

The legislative authority granted was very broad, e.g., id. at 155 ("And you the said A. B. by and with the consent of our said Council and Assembly, or the major part of them respectively, shall have full power and authority to make, constitute, and ordain laws, statutes, and ordinances, for the public peace, welfare, and good government of our said province"). Governors also had the arguably legislative powers, without need for assembly consent, to "constitute" as well as appoint judges, id. at 158; to dispose of lands, $i d$. at 162; and to establish fairs, markets, and harbors - considered aspects of the power to "regulate Commerce," $i d$. at 163.

See also EHD, supra note 1, at 195 (editor's note) (observing that "By the eighteenth century, the commissions of royal governors had arrived at a standard pattern," and setting forth as an example the commission of New York governor George Clinton, issued Jul. 3, 1741).

501 E.g., Del. Const., art. 5 (1776) (granting to the legislature "all other powers necessary for the legislature of a free and independent State"); GA. Const. (1777), art. VII (granting to the legislature "power to make such laws and regulations as may be conducive to the good order and well-being of the State"). Other constitutions without detailed enumerations of legislative powers include Md. Const. (1776), N.C. Const. (1776), N.H. Const. (1784), Part II (enumerating separately from a general legislative grant only the power to constitute courts); N.J. Const. art II (granting indefinite legislative authority); N.Y. Const. (1777), art. II (stating a general legislative grant); PA. Const. (1776), § 2 (granting "supreme legislative power") \& § 9 (granting to the legislature, in addition to authority to regulate its own proceedings, "all other powers necessary for the legislature of a free state or commonwealth"); S.C. Const. (1776), art. VII (general grant of legislative authority to "the president and commander-in-chief, the general assembly and legislative council"); S.C. Const. (1778), art. II (vesting legislative authority in a general assembly); VA. Const. (1776) (creating a legislature without a specific grant of authority).

502 Mass. Const. (1780), Part II, ch. I, § 1, arts III \& IV.

503 Id. Part I, Art. X (requiring personal or legislative consent and reasonable compensation). 


\section{ThreE VIEWS ForWARD}

\section{A. Limitations ImPosed bY the BILL OF RightS}

The Constitution's plenary grant of a power to Congress ordinarily permits Congress to exercise it in any way and for whatever reasons it chooses. ${ }^{504}$ However, adoption of the first eight amendments on December 15, 1791 restricted previouslylegitimate exercises of federal authority, including postal authority. ${ }^{505}$ The Bill of Rights marks the first constitutional retreat from the British postal model.

Parliament authorized compensation for takings in road construction only as to certain kinds of land. ${ }^{506}$ The Fifth Amendment limited the exercise of eminent domain by requiring that the federal government always pay "just compensation." 507 The British Parliament could ban from the mail anything it wished. The Second Amendment probably restricted Congress in this respect. ${ }^{508}$ The Sixth $^{509}$ and Eighth ${ }^{510}$ Amendments limited the scope of Congress's ability to define the procedures and punishments for postal crimes.

Most importantly, the First and Fourth Amendments limited the role of postal institutions as instruments of political control. The Fourth Amendment restricted the kind of warrantless mail searches previously so common ${ }^{511}$ —although, admittedly, much previous mail-opening was already illegal. ${ }^{512}$ After ratification of the FirstAmendment, ${ }^{513}$

504 United States v. Darby, 312 U.S. 100, 114 (1941) (stating that motive or consequence of an otherwise valid regulation of commerce does not render that exercise unconstitutional); Champion v. Ames, 188 U.S. 321 (1903) (upholding use of commerce power to prohibit trafficking in lottery tickets; $c f$. ROGERS, supra note 1, at 47-57 (discussing the promotion of social policies by banning items from the mail).

505 The Ninth and Tenth Amendments were explanatory or declarative rather than substantive. Robert G. Natelson, The Original Constitution: What It Actually Said and Meant 195-96, 261-63, 264-68 (Apis Books, 3d ed. 2014).

506 E.g., 1 Geo. 3, c. 35 (1761) (published as An Act for Amending the Road from Sacred Gate ...), at 7 (authorizing payment of damages for injury to some real estate, but not for injury to "Commons and waste Grounds").

507 U.S. CONST. amend. V ("nor shall private property be taken for public use, without just compensation.")

508 U.S. Const. amend. II ("A well regulated Militia, being necessary to the security of a free State, the right of the people to keep and bear Arms, shall not be infringed.").

509 U.S. CONST. amend. VI (guaranteeing speedy public trial by jury and other protections).

510 U.S. Const. amend. VIII ("Excessive bail shall not be required, nor excessive fines imposed, nor cruel and unusual punishments inflicted.").

511 Cf. Ex Parte Jackson, 96 U.S. 727, 727 (1877).

The constitutional guaranty of the right of the people to be secure in their papers against unreasonable searches and seizures extends to their papers, thus closed against inspection, wherever they may be. Whilst in the mail, they can only be opened and examined under like warrant, issued upon similar oath or affirmation, particularly describing the thing to be seized, as is required when papers are subjected to search in one's own household.

512 Supra notes 261-263 and accompanying text.

513 U.S. Const. amend. I ("Congress shall make no law respecting an establishment of religion, or prohibiting the free exercise thereof; or abridging the freedom of speech, or of the press; or the right of the people peaceably to assemble, and to petition the Government for a redress of grievances."). 
the federal government could still disseminate propaganda through the mail, but it could not ban opposing material. ${ }^{514}$ In this respect the First Amendment responded to Antifederalist fears that the new government would use postal institutions to suppress dissent. The First Amendment also promoted the post office's development into its later role as an instrument of public information and democratic participation. ${ }^{515}$

\section{B. THE Federal CongRess's Postal ACT OF 1792-and IMPLICATIONS FOR tHe NONDELEGATION PRINCIPLE}

Events occurring after May 29, 1790 (the day Rhode Island ratified the Constitution) generally are poor evidence of what the constitutional bargain meant to the parties earlier. This is especially true of events arising after adoption of the Bill of Rights. In reconstructing the original meaning of the Postal Clause, therefore, I have not relied on the Postal Act of 1792, adopted by the Second Federal Congress. ${ }^{516}$ But I do wish to offer reassurance to the curious.

Adoption of the Bill of Rights signaled a modest change in the postal mission. ${ }^{517}$ Professor Richard R. John argues that the 1792 statute was a far more profound change because it opened newspapers to the mail, protected the privacy of letter writers, and laid the foundation for postal expansion. ${ }^{518} \mathrm{He}$ is correct that the 1792 law encouraged publication and circulation of newspapers by affording them additional certainty and security. ${ }^{519}$ However, it did so mostly by reaffirming pre-constitutional usages. The statute's recognition of a right of free exchange among newspaper publishers ${ }^{520}$ codified a longstanding practice of the British and American post offices. ${ }^{521}$ Paid and franked newspaper carriage to subscribers had been a feature for decades, both in Britain and in America. ${ }^{52}$ A more significant change was standardization of newspaper delivery rates and diversion of the revenue from the carriers to the post office- but these changes had been part of

514 Cf. Jackson, supra, 96 U.S. at 727 (1877) ("Nor can any regulations be enforced against the transportation of printed matter in the mail, which is open to examination, so as to interfere in any manner with the freedom of the press. Liberty of circulating is as essential to that freedom as liberty of publishing").

515 E.g., DesAI, supra note 1 (discussing the interaction of the First Amendment and postal policy).

516 Act of Feb. 20, 1792, ch. 7, 1 Stat. 232.

517 Supra Part VII.A.

518 John, Spreading, supra note 1, at 31; see also Desai, supra note 1, at 683 (claiming that "the historical origins of the postal network as a vehicle for distribution of news ... culminated in the passage of the 1792 Post Office Act.").

519 Adelman, supra note 1, at 746 ("By establishing a standard policy, the 1792 Act effectively established newspapers as the main source of news in the United States and affirmed the post office as the main network for the circulation of political debate.").

520 Act of Feb. 20, 1792, ch. 7, 1 Stat. 232, §§ 21 \& 22.

${ }^{521}$ Adelman, supra note 1, at 723 (mentioning the exchange custom).

522 See, e.g., FINLAY, supra note 1 , at $41 \& 43$ (complaining of the volume of newspapers carried in 1773 and 1774); Adelman, supra note 1, at 712 (noting the role of the post office in newspaper distribution by the 1770s); id. at 718 (noting use of the frank to disseminate newspapers). 
the Confederation Congress's 1787 draft ordinance, ${ }^{523}$ and are not of constitutional significance.

As for the contention that the 1792 law protected the privacy of letter writers by prohibiting mail tampering, it is difficult to see how this was a significant change. Most postal tampering always had been illegal. ${ }^{524}$

Professor John's assertion that the 1792 law laid the basis for future growth is difficult to evaluate, for there is strong reason to believe growth would have come in any event. Both the slow growth of the postal system during the ContinentalConfederation era and the faster expansion later are better explained by factors other than the marginal changes in the 1792 law. ${ }^{525}$ The question is, in any event, not a constitutional one, and outside the scope of this Article.

Congressional debate on the 1792 law sometimes is treated as a landmark in the constitutional history of the Supreme Court's "nondelegation principle." 526 To be sure, most of the Second Federal Congress's delegation decisions were uncontroversial: It prescribed in the statute those subjects formerly determined by its Continental and Confederation predecessors, and delegated to the executive subjects formerly delegated. ${ }^{527}$ But one significant delegation issue proved more difficult: To what extent did the Constitution permit Congress to grant the executive the authority to "establish post Roads?" British and American history offered precedents in both directions, and the Senate and House split on the question. ${ }^{528}$

In the modern era, when Congress routinely delegates massive authority to administrative agencies, legal commentators may opine that constitutional scruples over delegation were "little short of absurd" 529 because "in most respects, management is an executive, not a legislative function." ${ }^{530}$ However, this position

\footnotetext{
32 J. Cont. Cong., supra note 1, at 55 (Feb. 14, 1787).

524 Supra notes $80 \& 261-263$ and accompanying text.

525 Among the reasons for slow growth were the war and, as Professor John recognizes, the limitations of Postmaster Bache. John, Spreading, supra note 1, at 27. Among the reasons for faster growth later were relative peace, the First Amendment, increased literacy, Jacksonian democracy, technological progress, and the nation's explosive population and territorial expansion.
}

The net effect on growth of Congress's decision to retain control over postal routes is also unclear. Intuitively, it would seem that granting the postmaster more flexibility would have been growth-friendly, but some believe that the congressional decision promoted expansion. Richard B. Kielbowicz, Preserving Universal Postal Service as a Communication Safety Net: A Policy History and Proposal, 30 Seton Hall Legis. J. 383,394 (2006) (suggesting that congressional retention of power to designate routes contributed to system expansion).

526 E.g., Gary Lawson \& Guy Seidman, "A Great Power of Attorney:" Understanding the Fiduciary Constitution 118-24 (2017) (discussing the congressional debate and its implications for the nondelegation principle).

527 Cf. Mashaw, supra note 1, at 1294 (noting the statute's mixture of prescription and delegation.

5281 Annals of Cong. 1579 (Apr. 13, 1790) (recording House objections to the Senate bill because of its delegation of power); id. at 1743 (Jul. 22, 1790) (recording disagreement in conference committee).

529 E.g., Currie, supra note 1, at 631-32 (labeling the congressional decision "little short of absurd"). See also David P. Currie, The Constitution in Congress: The Federalist Period, 1789-1801 146-49 (1997) (assessing the controversy).

530 Currie, supra note 1 , at 632. 
begs the question at issue: Where does the Constitution draw the line between "most respects" and the lesser number of respects encompassed within the phrase "Congress shall have Power . . . to establish ...." ${ }^{531}$ Here are some of the constitutional $^{532}$ factors the Second Federal Congress had to consider:

- The 1782 Confederation postal ordinance authorized the postmaster general to add posts "to and from such other parts of the United States, as from time to time, he shall judge necessary." 533 This precedent argued for the constitutionality of delegation. It was a very weak precedent, however, because in practice Congress retained tight control over creation of new postal routes. ${ }^{534}$ The congressional records contain many references to Congress fixing routes $^{535}$ and few, if any, to the postmaster general opening routes sua sponte. ${ }^{536}$ The 1787 draft ordinance would have aligned the law with practice by omitting the postmaster's authority to create new routes. Instead he was to fix them "as Congress shall from time to time direct." 537

531 This was not the only case in which the Constitution granted executive power to Congress. Another was the power to declare war, U.S. CoNST. art. I, $\S 8$, cl.11, traditionally an executive prerogative. J.L. DeLolme. The Constitution of England 76 (1790).

532 To the constitutional factors were added prudential considerations. E.g., 1 AnNals of Cong. 1697-98 (Jun. 15, 1790) \& 1734 (Jul. 8, 1790) (recording debates on wisdom of delegating power to designate post roads).

53323 J. Cont. Cong., supra note 1, at 670 (Oct. 18, 1782) (reproducing post office ordinance).

534 Previous writers on the delegation issue seem to have relied on the 1782 ordinance without examining actual practice or the 1787 revision, e.g., Currie, supra note 1 , at 629 \& note 133 .

535 E.g., 29 J. Cont. Cong., supra note 1, at 807-08 (Oct. 5, 1785) (resolution instructing the postmaster general to establish cross posts); $30 \mathrm{id}$. at 15 (Jan. 5, 1786) (resolution directing him to establish a post between Philadelphia and Fort Macintosh); $31 \mathrm{id}$. at 531 (Aug. 21, 1786) (reproducing postmaster general report requesting authorization for cross posts); $34 \mathrm{id}$. at 274 (July 3, 1788) (reproducing congressional resolution instructing the postmaster general to employ posts by a specified route between Philadelphia and Pittsburgh); 34 id. at 161-63 (May 20, 1788); id. at 174 (May 22, 1788) (reporting congressional debates over proposed routes for Pennsylvania, Massachusetts, and Delaware). Moreover, the resolution of July 3, 1788 contains language assuming Congress had fixed all cross-posts:

Resolved, That the Post Master General be and he hereby is authorised and instructed to make arrangements for the transportation of the mail for one Year from the first day of January next on the cross roads mentioned in the resolves of Congress passed the $4^{\text {th }}$ Sep $^{t} 1786$ and the 27 th of July

1787 on the principles provided in the resolution of the 15th Feb 1787.

536 Of course, it is possible that my research assistant and I missed one or more. We did find one reference to opening a route without clarifying who opened it. $34 \mathrm{id}$. at 82-83 (Mar. 4,1788 ) (reproducing postmaster general's letter referring to a post to Portland, Maine).

$53732 \mathrm{id}$. at 46 (Feb. 14, 1787). The draft ordinance did, however, "authorize and direct" the postmaster general to establish cross-posts "between the great post road, and all the ports of entry throughout these United States," id. 51-52, but these precise directions are of course different from the 1782 ordinance's grant of power to establish postal roads 
- The Constitution seemed to adopt Confederation practice by granting sole authority to Congress to "establish Post Offices and post Roads."

- This wording was clearly distinguishable from the Parliament's grants to the executive of authority "to establish Post Offices and Post [sic] Roads." 538

- The ratifying public would be justified in assuming that the congressional role under the Constitution would be similar to existing practice. Both advocates and opponents of the Constitution represented the Constitution's postal power as the same as under the Articles of Confederation. ${ }^{539}$ If disputants thought the Postal Clause represented a sharp break from the past, it would have been more controversial.

- Contemporaneous rules of legal construction, influenced by fiduciary values ${ }^{540}$ firmly disfavored delegation. The relevant founding-era legal maxims were delegatus delegare non potestone to whom a power is delegated cannot delegate it - and delegata potestas non delegari: a delegated power cannot be delegated.

On balance, these factors strongly suggest the Second Congress reached the correct constitutional decision when it refused to delegate authority to designate post roads. ${ }^{541}$

wherever the postmaster general "shall judge necessary."

5387 Geo. 3, c. 50 (1767), $\$ 5$ (granting authority in exactly those words to the postmaster general when extending service to the Isle of Man); 5 Geo. i, c. $21 \S 11$ (granting authority to postmaster general and his deputies to establish "penny post" offices).

539 E.g., Cumberland Gazette, Nov. 15, 1787, in 4 Documentary History, supra note 1, at 245-46; Plan of the Federal Constitution, Apr. 2, 1788 in 9 Documentary History, supra note 1, at 661, 673 (listing the post office power in a list of powers, most of which "the present Congress possess").

540 See generally Gary Lawson, Robert G. Natelson, and Guy Seidman, The Fiduciary Foundations of Federal Equal Protection, 94 B.U. L. Rev. 415 (2014) and sources cited therein.

541 Professor Currie argues that the 1792 statute delegated more authority than initially appears, Currie, supra note 1, at 631 (observing that the statute empowered the postmaster to place deputies "at all places where such shall be found necessary," Act of Feb. 20, 1792, ch. 7, 1 Stat. 232, $\S 3$ (emphasis added), and that the postmaster general could "extend the line of posts" by contract. $I d$. $\S 2$ ). However, the "necessity" referred to could mean merely the necessity of serving posts established by Congress. This language is different from that used for deciding whether to use stages or horses ("as he may judge most expedient"). In foundingera drafting practice, the former wording granted less authority. Robert G. Natelson, The Legal Origins of the Necessary and Proper Clause, in LaWson, ET AL., supra note 1, at 72-76 (2010) (explaining the variations in founding-era "further-powers" clauses).

With respect to $\S 2$, Professor Currie has a better case. However, there are answers to his rhetorical question of why the difference between direct designation and designation by contract mattered. Currie, supra note 1, at 631n. 145. Those answers are (1) contractual designations were only temporary commitments, and (2) they were limited to "extensions" of existing post roads. Overall, delegation was narrower than in the 1782 ordinance. 


\section{The Commendable Future of EBenezer Hazard}

Amid this relative institutional continuity, there was a change in personnel. The administration of Ebenezer Hazard had been marred by the newspaper delivery controversy, but congressional committee reports in 1783 and again in 1788 demonstrated that, overall, he had done a very good job with a defective institutional model. ${ }^{542}$ To run a profit despite franking exemptions, a very small staff, and persistent congressional interference was a triumph of management.

Nevertheless, George Washington was angry with Hazard over the ratificationera delivery problems. ${ }^{543}$ Just as the Antifederalists suspected Hazard of creating the delivery mess to promote the Constitution, Washington may have suspected him of creating it to defeat the Constitution. ${ }^{54}$ When Washington became president he replaced Hazard with treasury commissioner Samuel Osgood. ${ }^{545}$ The president did not have the courtesy to inform Hazard that he was being replaced; the poor man learned of it in the streets. ${ }^{546}$ So after dedicating much of his adult life to federal service, Ebenezer Hazard found himself without a job or any prospect for one, and with a wife and family to support.

As sometimes happens in the wake of political injustice - the career of Cicero comes to $\operatorname{mind}^{547}$ - the outcome proved fortuitous. Hazard returned to Philadelphia where he co-founded the Insurance Company of North America. ${ }^{548}$ This gave him sufficient financial support to indulge his scholarly disposition. He soon returned to a project he had begun in the $1770 \mathrm{~s}:{ }^{549}$ collecting American historical documents for publication.

Hazard eventually published two volumes of documents, thereby claiming the title of America's first historical editor. His compilations served as a crucial resource for an entire generation of American historians. ${ }^{550}$

54224 J. Cont. Cong., supra note 1, at 329 (May 5, 1783) (reproducing a laudatory committee report); $34 \mathrm{id}$. at 462, 463 (Aug. 27, 1788) (reproducing a committee report praising certain post office procedures).

543 Letter from George Washington to John Jay (July 18, 1788), in 16 Documentary History, supra note 1, at 595 (complaining of Hazard's use of riders rather than coaches).

544 Shelley, supra note 1, at 60.

${ }_{545} 1$ AnNAls OF CONG. 93 (Sept. 26, 1789) (containing Washington's announcement); LeECH, supra note 1 , at 11.

546 Shelley, supra note 1, at 60-61.

547 Cicero's absence from politics during the ascendancy of Julius Caesar (46-44 B.C.E.) was adorned by a written creativity that laid the foundation of philosophy in western Europe. Anthony Everitt, Cicero: The Life and Times of Rome's Greatest Politician 251-59 (2001).

548 Shelley, supra note 1, at 68; Pilcher, supra note 1, at 8.

$549 I d$. at 46 . Hazard apparently had been able to make some progress on this project while working for the post office, but before he became postmaster general. Letter from Samuel Adams to James Warren (Sept. 22, 1778) in 10 Delegate LetTERs, supra note 1, at 680 (recommending Hazard and his document collection project); Letter from Samuel Huntington as president of Congress to Thomas Jefferson (Apr. 27, 1781) in 17 Delegate LetTers, supra note 1, at 188 (containing similar recommendation).

550 Shelley, supra note 1, at 71-72. On Hazard's scholarly accomplishments, see also Pilcher, supra note 1, and Lawrence Shaw Mayo, Jeremy Belknap and Ebenezer Hazard, 178284, 2 New. ENG. Q. 183 (1929). 
The termination of the Confederation Congress freed its long-time secretary, Charles Thomson to labor on a translation of the Septuagint from Greek to English. Ebenezer Hazard acted as Thomson's consultant on the mechanics of book publication. Because Hazard had the benefit of an excellent classical education, he was able to serve as Thomson's editor and translation critic. As Thomson's published correspondence demonstrates, Hazard thereby strongly influenced the first-ever English rendition of the oldest extant version of the Bible. ${ }^{551}$

551 Pilcher, supra note 1, at 11. See generally Paul Odell Clark, Letters of Charles Thomson on the Translation of the Bible, 33 J. Pres. Hist. Soc'y 239, 242-43 (1955) \& 34 id. 112 (1956). 